UNIVERSIDADE DE SÃO PAULO

FACULDADE DE FILOSOFIA, LETRAS E CIÊNCIAS HUMANAS

JEMIMA DE SOUZA ALVES

É Londres, meu caro: o encontro de culturas em tradução

São Paulo

2019 


\section{É Londres, meu caro: o encontro de culturas em tradução}

Versão Corrigida

Dissertação apresentada à Faculdade de Filosofia, Letras e Ciências Humanas da Universidade de São Paulo para obtenção do título de Mestre em Letras.

Área de Concentração: Estudos Judaicos e Árabes

Orientadora: Profa. Dra. Safa Alferd Abou-Chahla Jubran

São Paulo 
Autorizo a reprodução e divulgação total ou parcial deste trabalho, por qualquer meio convencional ou eletrônico, para fins de estudo e pesquisa, desde que citada a fonte.

Catalogação na publicação

Serviço de Biblioteca e Documentação

Faculdade de Filosofia, Letras e Ciências Humanas

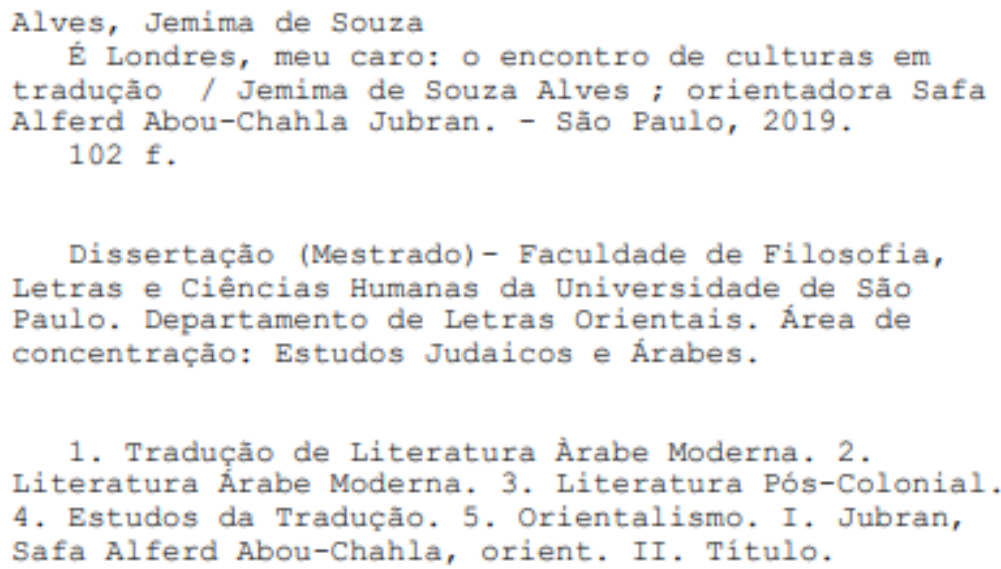


2. fflch universidade de são paulo

FACULDADE DE FILOSOFIA, LETRAS E CIENCIAS HUMANAS

\section{ENTREGA DO EXEMPLAR CORRIGIDO DA DISSERTACุÃO/TESE}

Termo de Ciência e Concordância do (a) orientador (a)

Nome do (a) aluno (a): Jemima de Souza Alves

Data da defesa: $23 / 07 / 2019$

Nome do Prof. (a) orientador (a): _ Profa. Dra. Safa Alferd Abou Chahla Jubran

Nos termos da legislação vigente, declaro ESTAR CIENTE do conteúdo deste EXEMPLAR CORRIGIDO elaborado em atenção às sugestões dos membros da comissão Julgadora na sessão de defesa do trabalho, manifestando-me plenamente favorável ao seu encaminhamento e publicação no Portal Digital de Teses da USP.

São Paulo, $23 / 09 / 2019$

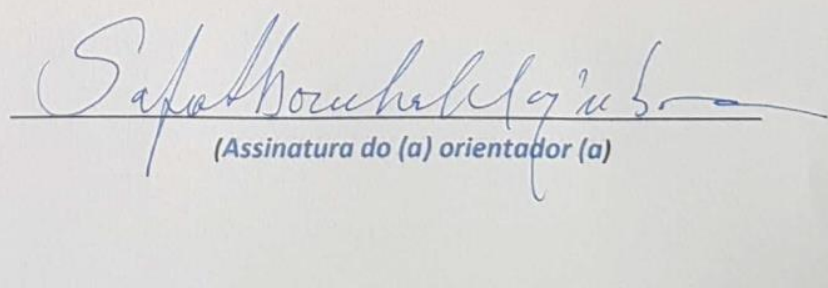




\section{Agradecimentos}

$$
\text { أشكره، هو، مَن كوّن كل شيء وبغيره لم يتكوّن أي شيء مدّا تكوّنَ. }
$$

Aos meus queridos pais, Alciso e Neide Alves, que me amaram e me apoiaram oferecendo suporte emocional e financeiro para que eu realizasse esse trabalho.

À minha irmã, Gislaine, minha amada amiga e companheira que viveu comigo as alegrias e dissabores de cada etapa desse árduo processo.

$$
\begin{aligned}
& \text { كما أتوجه بجزيل الثكر الى معلمتي ومشرفتي وصديقتي التي أيقظته بداخلي عشق اللغة والأدب }
\end{aligned}
$$

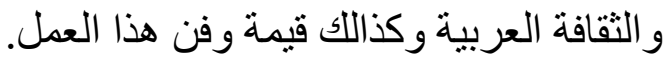

Ich bedanke mich bei Familie Kraus, meiner Familie in Deutschland und besonders bei Norbert und Gitte. Sie haben mich in ihrem Haus herzlich aufgenommen um einen Teil der Masterarbeit zu schreiben.

À minha querida prima, Eline Kraus, que mesmo vivendo do outro lado do mundo, ouviu pacientemente as questões que embasaram esse trabalho.

To Marco Ruckstuhl, my dear friend, for making possible access to the fundamental bibliography of this work at SOAS University of London and showing me the most interesting places of this amazing city.

Ao Wellington Silva, meu grande amigo, pelas monitorias de sintaxe e pelas longas conversas que transpôs nossa amizade de Espec. de CP ao nível do discurso.

Ao Felipe Benjamin, a quem admiro como pessoa e pesquisador e que acompanha minha pesquisa desde o projeto inicial.

$$
\begin{aligned}
& \text { أثكر اساتذة قسم الدر اسات الثرقية منى حاوي ومحمد الجاروش و أرلين كليميشا وميشال سليمان } \\
& \text { وميغيل عطية فيليو وكل الزملاء. }
\end{aligned}
$$

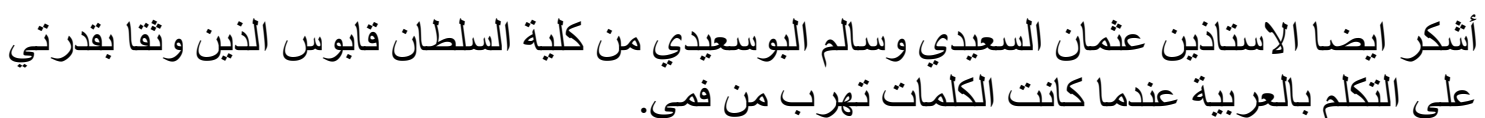

Ao Gabriel Johanson por todas as caronas da USP para casa, tornando os exaustivos dias divididos entre sala de aula e biblioteca um pouco mais leves.

À CAPES pela concessão da bolsa de mestrado e pelo apoio financeiro para a realização desse trabalho.

$$
\text { انها لندن با عزيزي }
$$

É Londres, meu caro. 
”لأن الدكان هو كالثخصية لها تجاربها وقو انينها وأسسها، تؤثر وتتأثر بما يدور حولها ." حنان الثنيخ

"Pois o lugar é como um personagem, tem experiências, leis e fundamentos próprio, influencia e é influenciado por tudo que o rodeia."

Hanan Al-Shaykh 


\section{Resumo}

ALVES, J.S. É Londres, meu caro: o encontro de culturas em tradução. 2019.102 f. Dissertação (Mestrado em Letras) - Faculdade de Filosofia, Letras e Ciências Humanas, Universidade de São Paulo. São Paulo, 2019.

Predominantemente representados a partir de imagens estereotipadas difundidas pelas grandes mídias internacionais, os povos árabes são sempre associados ao contexto de guerras, terrorismo e fundamentalismo religioso. Muito embora detenham uma cultura literária vastíssima, são pouco lidos através da produção de seus grandes escritores, tendo sua identidade cultural construída a partir do que se diz nas manchetes jornalísticas. Considerando o potencial que a tradução tem de formar identidades culturais nas comunidades receptoras e constituir-se uma forma de resistência, inovação e mudança cultural, no presente trabalho, propomos a tradução de excertos do romance Innaha London ya $a z \bar{l} z \bar{l}$, da escritora libanesa Hanan Al-Shaykh. Temos por objetivo realizar uma tradução que reconheça e evidencie traços da alteridade e receba o Outro enquanto Outro. Embora também defendamos que nenhum texto é capaz de transmitir uma visão geral de outra cultura, mas, pelo contrário, provê elementos que, de certa forma, somamse às imagens que representam uma cultura, de modo a manifestar elementos para autodefinição. Disto decorre que o texto traduzido nunca compreende completamente um gênero existente em uma certa cultura, mas contribui para o processo dinâmico do diálogo no sistema literário. Além disso, o texto traduzido não transmite o mesmo significado produzido na língua de partida, pois as interpretações possíveis são concebidas baseadas nos recursos e limitações presentes na língua, no imaginário social, e sistema literário da comunidade de recepção. Portanto, os efeitos produzidos através de um texto traduzido no sistema literário não podem ser previstos, embora funcione como uma força de representação da alteridade e de autorrepresentação.

Palavras-chave: Hanan Al-Shaykh; Literatura Árabe; Literatura Pós-colonial; Literatura Migrante; Estudos da tradução 


\begin{abstract}
ALVES, J.S. It's London, my dear: the encounter of cultures in translation. 2019. 102 f. Thesis (Master in Arts and Literature), University of São Paulo. São Paulo, 2019.

Predominantly represented by stereotyped images spread by the international media, Arab peoples have always been related to the context of war, terrorism, and religious fundamentalism. Although they possess a vast literary culture, they are hardly read through the production of their great writers, having their cultural identity constructed based on what is said about them in the journalistic headlines. Thus, we propose to present the translation of excerpts from the novel Innahā London ya azizz $\bar{l}$ (2001), written by the Lebanese writer Hanan Al-Shaykh, considering the potential of the translation in shaping cultural identities in host communities. We aim to perform a translation which recognizes, and evidences traces of otherness receives the other as Other. Although, we also defend that no translated text is able to convey a full survey of another culture, but provides elements, which somehow add to the images of culture and as such provides material for self-definition. Hence translated text never comprehend totally an existent genre in a certain culture; instead, it contributes to the dynamical process of dialogue into the literary system. Besides that, no translated text conveys the same meaning produced in source-language; for the possible interpretations are conceived based on the limitations and resources present in the target language, the social imaginary, and the literary system of the target-community. Therefore, the effects produced by a translated text into the receptor literary system cannot be foreseen, although it certainly will function as a force of representation of others and self-definition.
\end{abstract}

Keywords: Hanan Al-Shaykh; Arabic Literature; Postcolonial Literature; Migrant Literature; Translation Studies 


\section{SUMÁRIO}

INTRODUÇÃ

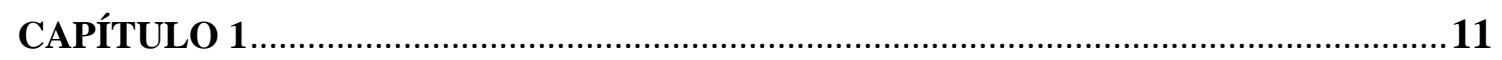

Hanan Al-Shaykh, uma escritora rebelde e feminista relutante ........................ 11

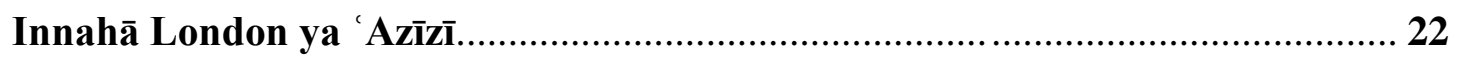

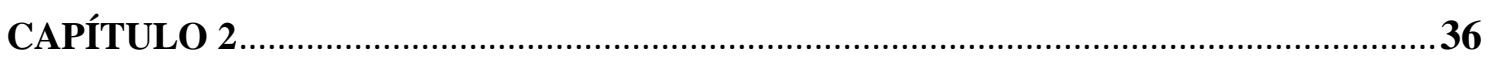

A emergência das romancistas e a literatura árabe pós-colonial em tradução... 36

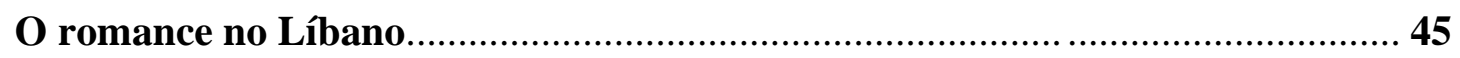

O contexto da tradução da literatura pós-colonial..............................................52

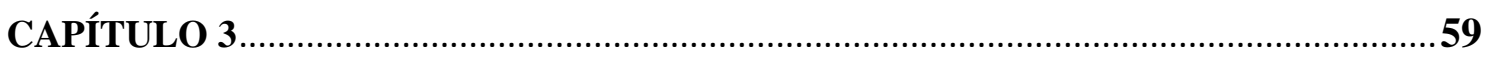

A tradução de Londres: problemas, escolhas e soluções........................................ 59

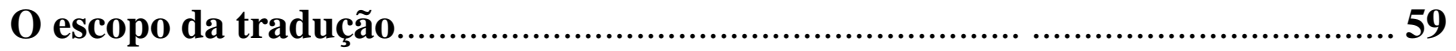

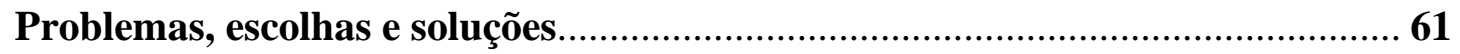

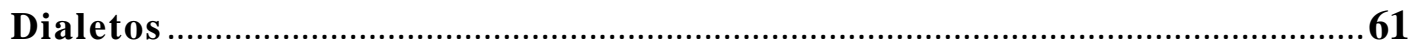

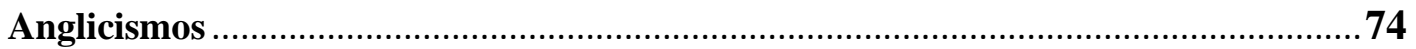

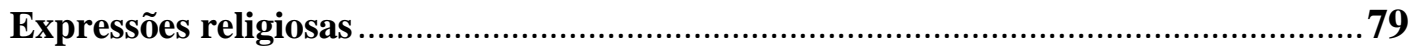

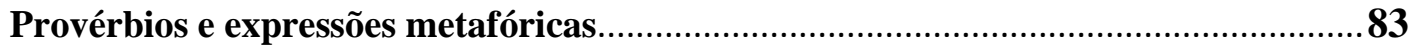

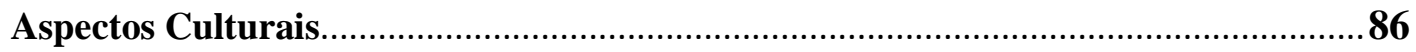

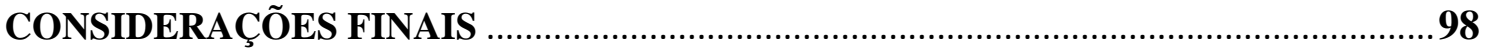

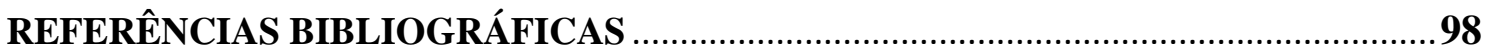




\section{INTRODUÇÃO}

A tradução, como crítica e comentário, ela mesma, é velada ao seu leitor, que desconhece todo o processo de desconstrução do texto para que uma nova obra seja criada. Deste modo, os comentários que constituem o terceiro capítulo do presente trabalho consistem no desvelamento desse processo, ou seja, será a enunciação de nossa leitura e interpretação do romance Innahā London ya 'azizz $\bar{l}^{1}$ (2001), da escritora libanesa Hanan Al-Shaykh, na tradução e criação de sua versão em português brasileiro, qual seja,

\section{É Londres, meu caro.}

Fruto de sua longa estadia na capital britânica, Al-Shaykh revela toda sua personalidade provocativa através da construção de seus personagens e das opiniões que eles guardam sobre a cidade. A autora, procurando se distanciar das obras produzidas por seus pares, cria uma atmosfera bastante heterogênea ao longo de sua narrativa, caracterizada pelo processo de imigração e o encontro de alteridades.

A necessidade de expor sua versão da história através do gênero pós-colonial, enriquece o sistema literário árabe por diferir de seus pares, na medida em que explora de maneira profunda o encontro do Oriente com o Ocidente na representação da multiculturalidade, seja ela nos diversos elementos culturais que compõem a cidade, nos idiomas e suas variantes, nas relações entre os indivíduos e a capital britânica, ou nas relações sociais.

A riqueza de detalhes ao representar o choque do encontro nos faz refletir sobre o desconhecimento que o Ocidente ainda possui a respeito dos povos árabes, dada sua arrogância em acreditar na sua supremacia cultural e intelectual.

Buscamos, neste trabalho, demonstrar o papel do tradutor enquanto mediador intercultural, assim como um leitor privilegiado que penetra camadas do texto de partida, que, bem possivelmente, não serão acessadas pelo leitor do texto de chegada. Desse

\footnotetext{
${ }^{1}$ Para o presente trabalho, padronizamos as transliterações dos nomes árabes e títulos de obras segundo a proposta apresentada em Jubran (2004), que prevê três níveis de padronização, o primeiro compreende textos acadêmicos, do qual faremos uso no corpo do texto desta dissertação, respeitando, é claro, os autores e trabalhos cujas transliterações já são cristalizados; o segundo que considera o leitor médio, utilizado na mídia escrita, e um terceiro que faz uso dos símbolos do Alfabeto Fonético Internacional (IPA).
} 
processo, decidimos apresentar a tradução como crítica e criação, direcionada para um objetivo final.

O leitor do presente trabalho terá acesso ao resultado de nosso percurso sobre as teorias da tradução que lidaram diretamente com os textos árabes clássicos e contemporâneos. Bem como à crítica dos estudos pós-coloniais que dizem respeito à tradução como apropriação e espaço de domínio. Nossa tradução aqui procurou explorar a multiculturalidade representada na obra da autora e trazer à comunidade de chegada as complexidades do encontro de alteridades tão bem delineadas no romance.

Esta dissertação divide-se em três capítulos:

O primeiro se dedica a detalhar a história de Hanan Al-Shaykh e como fatos de sua biografia refletiram em suas obras, consolidando-a como uma escritora rebelde e feminista relutante. Ainda nessa seção, apresentamos a obra que se constitui corpus deste trabalho, Innahā London ya 'azīzì, É Londres, meu caro. A partir de um breve resumo e apreciação crítica, pretendemos delinear o contexto de produção do texto, bem como descrever os elementos-chave para a compreensão do enredo e de sua singularidade enquanto romance pós-colonial árabe.

Com vistas a situar o leitor na tradição da qual Al-Shaykh descende, assim como em que momento histórico da literatura árabe está fixado o romance em tela, no segundo capítulo, tratamos da emergência das romancistas árabes no quadro do movimento da Nahḍh (Renascimento Árabe) e da relevância que os trabalhos realizados por essas escritoras, por muito tempo negligenciados, têm para a historiografia da literatura árabe moderna e para modernização da língua árabe. Nesse mesmo capítulo, discutimos o surgimento da literatura pós-colonial e o processo de tradução desses textos para as línguas europeias de prestígio e seu impacto nas relações Oriente-Ocidente.

O terceiro e último capítulo dedica-se à apresentação da tradução de excertos do romance, os quais consideramos relevantes para dar ideia ao leitor da constituição da obra. Junto à tradução, propomos nossas escolhas, sugestões e opções, baseadas na nossa leitura crítica do romance. Ao final, apresentamos nossas considerações finais, tendo em vista toda a experiência de pesquisa, leituras críticas, assim como as questões resultantes das reflexões realizadas ao longo de todo o trabalho. 


\section{CAPÍTULO 1}

\section{Hanan Al-Shaykh, uma escritora rebelde e feminista relutante}

Nascida no Líbano, em 1945, e oriunda de uma família muçulmana xiita, Hanan Al-Shaykh começou a escrever aos 14 anos. Já aos 16 anos, submetia artigos para o jornal diário An-Nahār. Desde essa época, a escritora tinha consciência de que era isso que faria durante toda a vida, e foi motivada a escrever pela necessidade que tinha de transmitir seus sentimentos sobre o tédio e sobre como os pais não entendem os filhos. Iniciando a carreira como ensaísta de jornal, publicava na seção quinzenal dedicada aos estudantes da época. Só mais tarde, se dedicaria à produção de ficção.

Al-Shaykh (2013a) relata que sempre se sentiu muito à vontade quando escrevia. Inicialmente, dedicava-se a expressar determinados sentimentos que nutria pelas coisas e que, lentamente, passaram a habitar a alma de seus personagens. Ao desenvolver suas habilidades criativas, já não tinha necessidade de ter experienciado algo ou algum sentimento para ser capaz de imprimi-lo em um personagem.

Vivendo em Beirute durante a infância e a adolescência, a escritora afirma que sempre esteve cercada por mulheres habilidosas e muito inteligentes, que tinham um modo específico de lidar com a vida, sendo comparadas, por ela mesma, com Šahrazād. No entanto, Hanan Al-Shaykh, tendo como referência as existencialistas Simone de Beauvoir e Françoise Sagan, considerava-se mais moderna que suas vizinhas e todos que estavam a sua volta e, por isso, desejava mais que tudo deixar o bairro onde morava.

Por ironia do destino, assim que começou a publicar, passou a ser chamada de 'a nova Šahrazād'. Por um longo tempo pensou ser vítima de um cliché, e por diversas vezes indagava-se sobre as razões de lhe atribuírem esse epíteto: “Ah, é um cliché. Por que eles fariam isso? Eu não gosto da Šahrazād"23. Até que, tempos depois, um diretor britânico convidou-a para adaptar ao teatro uma versão de As mil e uma noites em língua inglesa, e a escritora dedicou-se a ler três edições árabes do texto.

A autora se negava a aceitar o epíteto a ela atribuído, pois, na sua opinião, Šahrazād nem sempre fora vista como uma heroína, sobretudo dentre as mulheres mais

\footnotetext{
${ }^{2}$ Doravante todas as traduções da língua inglesa, assim como do árabe, são nossas.

3 "Oh, it is a cliché. Why would they do that? I don't like Scheherazade."
} 
instruídas. Para elas, a personagem não passava de uma escrava que se dedicou ao ato de narrar para que não fosse morta pelas mãos de um rei. Al-Shaykh (2013b), assim como alguns críticos árabes, afirma que As mil e uma noites não era uma obra vista como um legado literário do cânon árabe, mas era considerada uma obra vulgar, um compilado de contos populares e nada mais.

No entanto, depois das leituras realizadas para as produções teatrais, a escritora chegou à conclusão de que todo árabe deveria ler a obra, pois suas narrativas encerram uma finalidade didática que, fora dos domínios da religião, revelam o quanto os árabes eram menos conservadores e falavam abertamente sobre assuntos que, posteriormente, passaram a ser considerados tabus, como a sexualidade, que é bastante explorada no texto.

Devido à relevância que a própria Al-Shaykh dá a As mil e uma noites, é impossível tratar de sua produção literária sem considerar o peso que a personagem Šahrazād teve no seu percurso enquanto escritora. A maneira como a autora encara a arte de narrar advém de sua consciência sobre a importância da história do prólogo moldura e de sua protagonista que, conhecida universalmente, atribuiu ao ato narrativo o potencial de livrar todo um reino da morte.

Quando criança, ela não possuía uma cópia da obra em casa, pela simples razão de que não tinham qualquer livro ou jornal, com exceção do Alcorão. As narrativas eram transmitidas através do rádio, e Al-Shaykh sentia que a voz de Šahrazād arrebatava-lhe da atmosfera pesada e nebulosa que inundava sua casa desde que sua mãe havia saído de casa para se casar com outro homem. Abandonado, seu pai nunca se recuperou da perda, e passou a devotar-se completamente à oração, refugiando-se na religião.

Com suas encantadoras histórias, a narradora permitiu-lhe viajar a terras distantes e fantásticas, habitadas por gênios e demônios que se escondiam em garrafas, lâmpadas mágicas, e se deliciavam em banquetes regados por bebidas e comidas raras, em palácios suntuosos, onde havia animais e pássaros imaginários. No entanto, quando teve a oportunidade de ler a obra pela primeira vez, já um pouco mais madura, Al-Shaykh afirma não ter gostado. O prólogo moldura da narrativa deixou a autora obcecada, principalmente pelas figuras de Šahrazād e do rei Šahryār - mais pela narradora do que pelas histórias 
em si: "Eu criticava Šahrazād continuamente por não ter apunhalado o rei com uma adaga"4 (ibidem).

Ao ler pela segunda vez As mil e uma noites, Al-Shaykh (2013b) observa que Šahrazād havia retratado a humanidade em suas diversas possibilidades: a narradora havia apresentado ao público, por meio de suas histórias, a individualidade humana sobre a qual as romancistas árabes, séculos depois, iriam reclamar em suas obras. Com sua nova leitura sobre Šahrazād, a autora entende que ela persuadiu a si mesma a não aceitar que a vida começava e terminava numa cama, como as outras virgens acreditavam.

Eu percebi que Šahrazād não estava contando histórias somente para salvar a si mesma, senão para mergulhar de cabeça numa aventura, para assumir riscos. Assim que ela decidiu dar um passo para o interior do mundo de um tirano poderoso e existir num tempo emprestado, ela colocou um pé no fio da espada, enquanto o outro permanecia fora ${ }^{5}$.

A autora segue,

Equilibrando-se entre a vida e a morte, a fim de postergar o momento em que perderia sua cabeça, ela forçou seu coração a prosseguir e a pensar também. Ela o adaptou com duas asas e deu-lhe uma ordem, dizendo: 'agora tente voar e ajude minha mente, meus cinco sentidos, e meu sexto também, a viajar em domínios do real e do fantástico, do conhecido e do desconhecido'. Por causa de sua tremenda força, o rei tornou-se um espectador, um viajante, diante dela ${ }^{6}$ (ibid.).

Depois da publicação de seu romance Barīd Beirūt 'Correio de Beirute', de 1992, passou-se atribuir à autora o epíteto de Šahrazād com uma frequência ainda maior, em resenhas de suas obras e em títulos de entrevistas, sobretudo de língua inglesa. A razão de ser logo em seguida da publicação desse romance, é devido à personagem central, Asmahān, uma refém em seu próprio país, que escreve cartas que provavelmente nunca

\footnotetext{
4 "I kept criticizing Shahrazad for not stabbing the king with a dagger."

5 "I realized that Shahrazad wasn't telling her tales only to save herself, but to plunge headlong into adventure, to take risks. As soon as she decided to step into the world of the mighty tyrant and exist on borrowed time, she put one foot on a sharp sword, and left the other free".

6 "Balancing between life and death, in order to postpone the moment when she'd lose her head, she forced her heart to have a go and think, too. She fitted it with two wings and gave it an order, saying, "Now try to fly and help my mind, my five senses, my sixth one too, to travel into the realms of the real and the fantastic, the known and the unknown." As a result of her tremendous strength, the king turned into a spectator, a voyeur, in front of her."
} 
chegarão ao seu destino. E, conforme ela escreve, como um processo de gestação, cada história gera dentro de si uma outra.

Até esse momento, Al-Shaykh (2013b) menciona que tinha muito clara a relação entre Šahrazād e as escritoras árabes - mesmo sabendo que a obra As mil e uma noites havia impulsionado a imaginação ocidental e que, de uma vez, foi considerada a epítome da cultura árabe, assim como havia considerado Jane Eyre e Elvis Presley como exemplos máximos da cultura ocidental. Porém, segundo a autora, agora, Šahrazād era a rainha da magia e do mistério, a mulher oriental que salvou a si mesma e sua parentela da tirania do rei, embora no imaginário árabe fosse considerada uma vulgaridade, uma vez que os intelectuais árabes que consideravam a obra uma parte talentosa da herança literária ainda pertenciam a um grupo bastante restrito.

Por causa de seu posicionamento em relação à Šahrazād e o potencial atribuído pela escritora à arte de narrar, Hanan Al-Shaykh evidencia sua concepção sobre o espaço literário como lugar perfeito para apresentação das demandas do ‘ser humano'. E sempre que acha pertinente, a escritora arrola uma sequência de títulos produzidos por mulheres árabes, com vistas a atestar que esses textos não se restringem ao universo feminino, mas contempla toda a esfera social; ela elenca temas tais como questão palestina, guerra civil, colonialismo, entre outros, que são claramente abordados nas obras às quais faz referência.

Em defesa da valorização da literatura produzida por mulheres, a escritora está sempre a citar os trabalhos das libanesas Labiba Hashim, Qalb Ar-rajul (Coração do homem), e Zaynab Fawwāz, Husn Awāqib: $\dot{G} \bar{a} d a$ Az-Zahrah (Boas consequências: $\dot{G} \bar{a} d a$, a flor), do final do século XIX, que discutem, já no alvorecer da $N a h d a h^{7}$, a ideia de que a emancipação das mulheres nunca seria alcançada sem homens e mulheres agindo conjuntamente, uma vez que ambos sofreriam com a estrutura opressiva da família e sociedade.

\footnotetext{
${ }^{7} N a h d ̣ h$ (em árabe: النهضض/An-Nahḍh: 'despertamento' ou 'renascimento') foi o processo de renascimento cultural que teve início entre o final do século XIX e o começo do século XX no Egito, e, posteriormente, alcançou os demais países arabófonos sob o domínio do Império Otomano.. É considerado o período de modernização intelectual e reforma no mundo árabe.
} 
Al-Shaykh (2013a) acredita que somente no final do século XX a literatura árabe tenha atingido uma maturidade no que diz respeito ao papel da mulher e no seu reconhecimento enquanto sujeito social. Ela enfatiza que os anos 1990 testemunharam o surgimento de uma nova geração de jovens escritores, sobretudo no Egito, que não queria mais seguir a linha do escritor Naguib $\mathrm{Mahfouz}^{8}$, mas buscava romper com as imagens sufocantes que haviam sido pintadas por escritores homens sobre a mulher. Esses escritores criavam personagens a fim de gritar: 'eu existo como ser humano', não como a reprodutora, ou como a mãe-terra, imagens bastante recorrentes nos textos de autoria masculina. Cabe aqui mencionar que a própria escritora, no seu romance Innahā London ya 'azizzi (2001), coloca essa fala nos lábios de uma prostituta marroquina, ao se afirmar diante da alteridade britânica (2001, p.74).

A autora reconhece o esforço de uma nova tradição na literatura contemporânea de tratar o personagem como um indivíduo que represa em si mesmo uma individualidade que transcende sua nacionalidade e seu status social, ou seja, há um processo de universalização das temáticas abordadas nos textos. Haja vista que a gênese do romance árabe se deu num contexto em que os escritores sentiram a necessidade de discutir as demandas da realidade cotidiana, e a identidade ocupava uma das posições centrais.

Situando sua própria literatura nessa nova tradição, Al-Shaykh demonstra, através das técnicas narrativas empregadas em suas obras, a compreensão que tem sobre a importância de como esses textos são construídos e sob quais perspectivas os enredos são engendrados. Fazendo uso da técnica narrativa da primeira pessoa do discurso na maioria de suas composições literárias, a escritora encontra um meio de dar expressão à consolidação do seu 'eu' no momento em que se ocupa de questões essenciais que dizem respeito à mulher e dá voz aos seus sentidos. Essa técnica transfere o controle narrativo totalmente ao sujeito feminino, trazendo-o da margem ao centro do texto literário, onde se torna a personagem central e a narradora dos fatos que governam o desdobrar dos

\footnotetext{
${ }^{8}$ Primeiro romancista árabe a ser premiado com o Nobel de Literatura, em 1988, o autor Naguib Mahfouz e sua literatura eram considerados um modelo a ser seguido, especialmente entre os egípcios cairotas, por isso a referência da escritora no trecho supracitado. Acredita-se que esse fenômeno foi de tamanha influência entre os escritores, que é possível falar-se em períodos Mahfuziano e pós-Mahfuziano. Isso para indicar a radical mudança na mentalidade e perspectiva que caracterizaram e canonizaram o texto do autor como representante do romance urbano, mais especificamente no milieu cairota (AL-MUSAWI, 2003, p. 21).
} 
eventos secundários. Quando o 'eu’ torna-se uma particularidade, ele é o assunto principal no texto (SIRHAN, 2016, p. 94).

De acordo com Sirhan (2016), esse controle narrativo atribuído à personagem feminina existe em decorrência da importância dada ao uso da primeira pessoa do discurso na narrativa de Al-Shaykh, e das outras escritoras árabes, cuja criação resultante indica a penetração, com audácia e seriedade, em questões comumente excluídas, especialmente porque a narrativa da mulher se aproxima da arte da tradução da subjetividade e da biografia literária.

A autenticidade desse discurso provoca em alguns críticos a impressão de que essa voz narrativa em primeira pessoa é empregada pelas autoras árabes como voz da confissão, fato que, de acordo com Allen (1995, p. 88 apud SIRHAN, 2016, p. 95), causa o efeito de uma história que reflete uma experiência pessoal, por isso o leitor se recusa a se convencer de que esse pronome refere-se à personagem e não à autora.

Esse fenômeno pode também ser observado nos trabalhos de outros grandes nomes da literatura árabe, como por exemplo, o escritor libanês Rachid Daif, que faz uso corrente de um tom autobiográfico em seus romances, e não só pela utilização da técnica narrativa de primeira pessoa, mas por também nomear seus protagonistas com o seu próprio nome (FRANCISCO, 2014, p. 14). O autor comenta que faz uso dessa estratégia para garantir que seu leitor tenha a sensação de estar testemunhando situações reais e íntimas que o escritor tenha experienciado e comenta:

Sinto uma liberdade extrema quando me imagino no lugar de um personagem de um dos meus romances [...]. descobri com o tempo que o prazer do leitor duplica quando lê um romance que considera ser a vida do seu criador. O seu gosto se intensifica. É natural que o ser humano goste de um certo 'voyeurismo' [baṣbașa], isto é, de espiar a intimidade dos outros e saber o que se passa nela (DAIF em entrevista, 2007 apud FRANCISCO, 2014, p. 14)

É por essa razão que grande parte das escritoras em muitos dos países árabes, até pouco tempo, publicavam seus trabalhos sob pseudônimos, pois uma vez declarados seus nomes verdadeiros, temiam ter suas obras associadas a uma biografia em que figuravam a protagonista, principalmente se o texto contivesse algumas informações que coincidissem com a vida pessoal e que dessem ao leitor a ideia de que o texto é verdadeiro e realístico. Por isso, é possível considerarmos o uso da primeira pessoa do discurso na narrativa de Al-Shaykh um recurso específico que evidencia incontestavelmente sua 
ousadia e liberdade das restrições impostas sobre ela, e com certeza a tendência essencial de sua literatura em relação à prática literária masculina nos níveis temático e formal (SIRHAN, 2016, pp. 95-96).

Embora valorize todo o progresso da literatura árabe contemporânea e todas as possibilidades que guarda nos gêneros desenvolvidos, Al-Shaykh (2000) demonstra ter em grande estima todo o legado cultural árabe e sua importância para cultura universal. A autora cita célebres nomes da Falsafah ${ }^{9}$, como Avicena e Ibn Khaldun, bem como as traduções antigas de Platão e Sócrates, para destacar a relevância da cultura áraboislâmica no pensamento universal. Não obstante esse reconhecimento, admite uma tendência da cultura árabe à ocidentalização quando comenta:

estou sendo cercada. Há uma pequeníssima cultura que eu posso chamar propriamente minha. Felizmente, hoje, a literatura ainda registra suas palavras numa página, romances e poesia continuam a ser publicados, e a criatividade encontra sua voz artística. Mas o árabe, essa minha solitária língua materna, implora por audiência, por um lugar, mesmo pequeno, distante da tagarelice estúpida de seus filhos - Mickey Mouse decora as lanternas celebrando o fim do Ramadã, no mais santo mês do calendário muçulmano ${ }^{10}$ (Ibid.).

Sua desilusão com a invasão da cultura euro-americana no mundo árabe, sobretudo no Líbano, é provocada toda vez que entra em um restaurante e recebe cardápios impressos nas línguas inglesa e francesa, e sempre que cumprimenta um garçom com 'Massa' Alheir' e em resposta ele diz 'Bonsoir'. Padarias, salões de cabelereiros, quiosques de fast-food exibem letreiros escritos com um inglês cômico. Ela assume: "Eu me tornei numa aspirante: uma aspirante francesa, uma aspirante americana, todo tipo de aspirante. Há culpados e vítimas nesta cidade global. Há vitoriosos e perdedores" $" 11$ (ibid.).

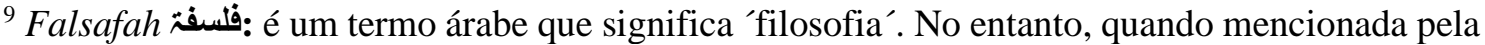
autora remete ao período clássico da filosofia entre os árabes, a partir do movimento de recepção e desenvolvimento da filosofia grega em territórios sob o domínio de império islâmico, entre os sécs. VIII e XIII d.C.

10 "But I am being besieged. There is very little culture that I can call my own anymore. Mercifully, today, literature still etches its words onto the page, novels and poetry continue to be published, and creativity finds its artistic voice. But Arabic, that lonely mother-tongue of mine, begs for an audience, for a place, however small, away from the mindless chatter of its children - Mickey Mouse decorates the lanterns celebrating the end of Ramadan, the holiest month in the Muslim year."

11 "I've become a wannabe: a French wannabe, an American wannabe, every kind of wannabe. There are culprits and victims in this global village. There are victors and losers."
} 
Por ter vivido mais de quarenta anos na Inglaterra, Al-Shaykh (2000) é consciente do lugar ocupado pela literatura árabe no cenário britânico e acredita que, para os ingleses e a comunidade ocidental no geral, o Egito é considerado Umm Ad-Dūnyā (a mãe do mundo), ou seja, o berço da civilização, portanto o país mais importante do mundo árabe. Por essa razão, os ingleses não estariam interessados nos romances libaneses, sírios, ou do norte da África, em geral. Depois do Egito, a Palestina seria alvo de atenção, principalmente pelos eventos políticos que tiveram palco na região, assim como o permanente conflito israelo-palestino, e após as visitas de Emile Habibi, romancista palestino, e Edward Said à capital britânica.

Com relação ao seu fazer literário, Hanan Al-Shaykh (2013a) argumenta que não pode ser ignorada pelo simples fato de estar ativa no Reino Unido por muitos anos. Para além disso, reconhece que escrever peças de teatro aumentou o seu índice de leitura, principalmente porque o teatro tradicionalmente é apreciado por uma audiência maior. Segundo a escritora, os anglófonos não estariam interessados nas questões árabes no geral, mas sim em romances que narram histórias que lhes são atrativas. E isso teria se tornado evidente com a repercussão da publicação de In the Country of Men (2006), 'No país dos homens', de Hisham Mattar, que oferece uma descrição da Líbia sob o regime de terror de Mu 'ammar al-Qaḍ̂â̄i e a narrativa de pessoas ordinárias tentando sobreviver à política opressora do ditador.

Al-Shaykh (2013b) acredita que a tradução de livros árabes, pelo menos no Reino Unido, não é tão popular. Além disso, com relação à qualidade literária das publicações, as editoras britânicas assinam, normalmente, apenas com autores cujos livros elas esperam lucrar muito com as vendas - realidade que não se difere da encontrada também aqui no Brasil. Ela explica ainda que foi a paixão que os britânicos nutrem pelo Egito o principal responsável pelo sucesso de The Map of Love (1999), 'O mapa do amor', de Ahdaf Soueif.

Sobre o desconhecimento arraigado na sociedade britânica a respeito dos países árabes e da tradição literária ali desenvolvida, a autora comenta:

Certa feita, eu conheci um editor de cultura de um dos maiores jornais do Reino Unido. Quando eu me apresentei a ele como uma escritora de ficção, ele respondeu admirado: 'Eu não sabia que as mulheres árabes escreviam'. Eu jocosamente presenteei-o com um dos 
meus livros e pedi a ele que confirmasse que a foto no livro era minha e que eu era realmente a autora do livro ${ }^{12}$ (AL-SHAYKH, 2013b).

Na ficção da escritora libanesa Hanan Al-Shaykh - da qual apenas uma parte do trabalho foi traduzido para as línguas inglesa, francesa e espanhola, e, para o português, há apenas um conto traduzido ${ }^{13}$-, as mulheres representam importantes papéis, mas em termos de enredo e conflito. Em alguns casos, suas protagonistas são mais responsivas do que ativas: vítimas de um patriarcado islâmico e tratadas como cidadãs de segunda classe, impotentes tanto política quanto economicamente. Confusas e passivas, elas se permitem transitar à deriva de um evento a outro (e, frequentemente, de um homem a outro), com uma pequena sensação de realização e consciência de que a situação pode ser mudada.

Em outras circunstâncias, quando elas tentam assegurar algum tipo de postura independente da autoridade masculina, é somente com uma sensação de relutância - não que isso seja seu direito, mas simplesmente uma questão de casualidade. É impossível pensar que suas personagens sejam feministas empenhadas, embora o simples fato de que Hanan Al-Shaykh, ela mesma, cuidadosamente, ao descrever as situações que entrincheiram as mulheres no mundo islâmico contemporâneo, identifique seu papel com esse de uma relutante porta-voz pela mudança na vida das mulheres (LARSON, 1991, p. 14).

Ao explorar a temática da sexualidade em sua literatura, a escritora reflete sua personalidade rebelde, disposta a confrontar costumes e tradições. Essa rebeldia, AlShaykh (2004) acredita advir do fato de não ter vivido em um lar tradicional, por conta da ausência da mãe. Embora a falta de controle parental tenha possibilitado sua insubordinação às tradições, a autora acredita que as pessoas carregam a rebelião em sua constituição genética.

\footnotetext{
12 "I once met a culture editor at one of the UK's major newspapers. When I introduced myself to him as a fiction writer, he responded in wonder: "I never knew that Arab women write." I jokingly presented to him one of my books and asked him to confirm that the picture on the book is mine and that I am the real author of the book."

${ }^{13}$ Assijāda al- 'ajamiya, 'O tapete persa', traduzido por membros do grupo de tradução Tarjama e publicado em Tiraz: revista de estudos árabes e das culturas do Oriente Médio, No 8 , pp. 81-89. São Paulo: FFLCH/USP, 2016.
} 
Ao descobrir que sua mãe havia deixado a família para fugir com um amante, AlShaykh relata que foi tomada de uma revolta que, possivelmente, a influenciou em seus trabalhos posteriores ao fato:

Eu me revoltei contra meu pai, que era muito religioso, e eu fui sincera com ele assumindo que eu mentia e que colocava o hijāb na minha bolsa e não na cabeça. Os meus parentes diziam que a minha vida seria difícil, porque eu me opunha e discutia. Eu só gostaria de dizer aqui que eu vivi uma vida diferente dos outros por causa da ausência da minha mãe. Eu levava a comida para o meu pai e tinha que caminhar por Beirute de mercado em mercado, lendo os escritos nos letreiros que tinham dizeres bonitos e que me encantavam ${ }^{14}$ (ibid.).

Sua concepção sobre os conflitos que permeiam a relação entre os sexos é refletida em sua literatura através da metáfora do incognoscível. Muitos de seus personagens masculinos agem como predadores, perseguidores de mulheres, porque eles sabem muito pouco a respeito delas: sexualmente, emocionalmente, psicologicamente. Outros simplesmente toleram a situação em que eles se encontram, demonstrando pouca ou nenhuma curiosidade sobre o sexo oposto (LARSON, 1991, p. 14).

Entre as obras da escritora, cuja qualidade tornou-se um marco para sua época, estão Intiḥār rajul mayyit 'O suicídio de um homem morto', de 1970, e Faras Ǎ̌šsaytān 'Cavalo do Diabo', de 1975. Apesar do sucesso dessas obras, sua escrita cristalizou-se no início dos anos 1980, ano em que a escritora publica às suas expensas o romance Hikāyah Zahrah 'História de Zahrah', por meio do qual desafiou as convenções e o decoro, e que, posteriormente, passaria a situar-se entre os trabalhos de ficção mais importantes do Oriente Médio.

Hikāyah Zahrah, 'História de Zahrah', narra de maneira hipnotizante, permeada pela sexualidade explícita, cenas da guerra no Líbano. Zahrah é uma garota desajustada, segundo os padrões sociais de sua época, e maltratada pela mãe, que a usa para encobrir seus encontros furtivos com um amante. Seu pai, um homem rude e autoritário, está sempre repreendendo-a por seu hábito inconveniente de espremer as espinhas do rosto. Em busca de liberdade, a garota deixa seus pais e vai viver com um tio que se refugiou

\footnotetext{
${ }^{14}$ Tradução de:

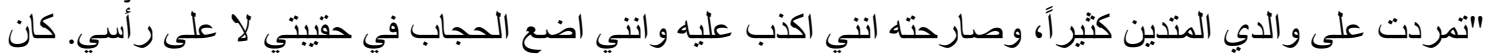

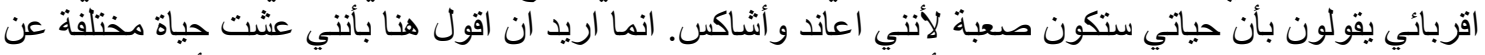

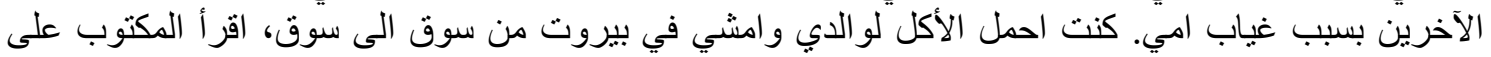
اللافتات وكان ثمة كلام جميل يسحرني".
} 
na África, fugindo de retaliações por causa de suas atividades políticas. Ao perceber que o tio manifesta por ela um desejo sexual, Zahrah decide casar-se com seu amigo Mājid.

Depois de algum tempo, a moça retorna à Beirute, onde a guerra havia, como gorgulhos dentro de um saco de farinha, encontrado lugar para se instalar, e passa a se relacionar sexualmente com um homem suspeito de ser um sniper. A narrativa em primeira pessoa dá voz a cada um dos personagens silenciados pelo horror da guerra. Embora, como protagonista, Zahrah tenha um espaço mais notável ao longo do enredo, também somos comovidos pelos relatos de outros personagens, como a descrição de Mājid sobre a sua excitação adolescente enquanto lia Jane Eyre e via uma ilustração de sua heroína beijando Mr. Rochester.

Nesse romance, que se passa no Líbano e na África, as mulheres são retratadas como extrínsecas, como inadequadas, como meros peões dos homens à sua volta. Suas vidas são precárias, sempre em tal fluxo e tal controle pelos homens que elas são pouco mais que vítimas. Os homens mesmos, no entanto, são incompetentes, sexualmente reprimidos, maridos fracos, talvez por causa de seu status privilegiado e mimado. Dispensa mencionar que não há um relacionamento homem-mulher positivo, nem pista de que possa haver até que as mulheres não sejam mais oprimidas (LARSON, 1991, p. 14).

Hikāyah Zahrah 'A história de Zahrah', parecia oferecer um mundo rico, no qual o destino de uma mulher oprimida funde-se ao destino de uma sociedade construída sobre contradições. A patologia de Zahrah torna-se cada vez mais nítida ante os contrassensos de vários segmentos da sociedade cada vez mais exacerbados, chegando, finalmente, ao clímax: a explosão do corpo de Zahrah e a implosão da sociedade civil. Seu trauma está enraizado na sua infância, no tempo anterior à guerra, quando ela havia internalizado todas as formas de autoridade social e opressão patriarcal. Conforme envelhece, a protagonista absorve os conflitos externos dentro do seu ser; seu sofrimento, ao refletir o sofrimento coletivo das mulheres, reverbera a forte ligação entre a miserabilidade das mulheres e a guerra (AL-'IDA, 2008, p. 30).

Esse círculo contínuo também pede a questão de para quem Hikāyah Zahrah 'A história de Zahrah', foi escrita - o próprio povo libanês de Al-Shaykh, um público muçulmano maior, ou para uma comunidade que extrapola os limites do mundo muçulmano? Propor essa questão sempre coloca a crítica (sobretudo a crítica ocidental 
de literatura não-ocidental) em solo perigoso. A resposta, porém, dá uma falsa ideia sobre o dilema de Al-Shaykh como romancista mulher no contexto árabe, tentando escrever fielmente sobre o mundo como ela conhece (LARSON, 1991, p. 15).

O seu assunto, muito naturalmente, torna-se o da mulher no patriarcado, e só garante um público leitor muito limitado em muitas áreas do terceiro mundo. Ao retratar o abuso a que muitas mulheres são submetidas dentro do contexto muçulmano, AlShaykh parece desenvolver um feminismo espontâneo que, segundo Larson (1991), estaria fora das divisas do dogma mais familiar de algumas de suas contrapartes ocidentais. De modo que, sem essa retórica, sua escrita transcende o lugar comum.

A despeito da prevalência do patriarcado no contexto em que a autora se encontra inserida, isso não implica que a ficção árabe seja desprovida de escritores homens que exponham a situação desfavorável da mulher no mundo árabe. Como também observado por Larson (1991), alguns pensam imediatamente em Zohrah, de Miramar, de Naguib Mahfouz - e pasmem com a similaridade entre os nomes ${ }^{15}$ - ou Hamīda, em seu Zuqāq al-Midaq, 'O beco de Midaq'. Lembrando-se dos anos que Hanan Al-Shaykh passou no Cairo, é impossível não assumir algum tipo de afinidade entre os dois trabalhos dos escritores.

Em 1994, a autora lançou uma coletânea de contos chamada 'Aknusu aš-šhams 'an as-suțūh (Eu varro o sol dos telhados). Nessa obra, assim como pontua Levi (1998), Al-Shaykh escreve com um conhecimento velado pela imaginação que é ao mesmo tempo educativa e sexualmente estimulante, explorando permutações e combinações da feminilidade árabe de uma maneira que lembra o Ocidente de que a matemática dos nossos números e a beleza de Alhambra emanam da mesma fonte árabe.

\section{Innahā London ya 'Az̄̄zì}

Fruto de sua longa residência na Inglaterra, em 2001, Al-Shaykh publica o romance Innahā London ya 'azīzī 'É Londres, meu caro', com intenções de expressar, através de seus personagens, sua própria experiência enquanto imigrante árabe no Reino Unido. Reconhecida entre os críticos como romance pós-colonial, a obra foi traduzida ao

\footnotetext{
${ }^{15}$ Zohra é, no dialeto egípcio, uma variação do nome Zahra, o mesmo dado à protagonista do romance de Al-Shaykh.
} 
inglês, espanhol e francês. A narrativa, como sugerido no título, tem como palco para o desenrolar de seu enredo a cidade de Londres, e seus protagonistas constituem-se majoritariamente de imigrantes árabes, exceto por um personagem britânico.

Oriundos de países diferentes, esses indivíduos apresentam inclinações e posições sociais díspares, bem como diferentes motivos que os levaram a viver na capital britânica e, principalmente, atitudes distintas no relacionamento com a alteridade inglesa. Os personagens, embora se conheçam e se encontrem ocasionalmente, possuem seu próprio enredo; suas relações não são de natureza orgânica, de modo que cada um dos protagonistas possui sua própria história independente da história do outro.

A narrativa, ao discorrer sobre o destino destes quatro protagonistas na cidade de Londres, aponta sempre para como a origem social desses personagens interfere diretamente na relação com a metrópole, fator que desencadeia as contingências de sua residência naquele lugar, suas ambições e sua consciência da realidade. O texto nos parece ainda expressar bem a ilusão que o imigrante tem de que, ao portar o documento que o 'legaliza' no país de imigração é possível tornar-se um 'deles'. No entanto, a experiência no espaço estrangeiro e o encontro com a alteridade, no decorrer da narrativa, traz à tona a luta identitária que se desdobra em cada um dos sujeitos, de acordo com os impasses que vão colocando-se frente a eles.

O romance inicia-se num curto prólogo, transcorrido num avião que parte de Dubai em direção à Londres. Esse primeiro momento, em que se dá o primeiro encontro dos personagens, guarda o cerne da narrativa que se desenrolará em torno de questões sobre desenraizamento, exílio, migração e perda, vivenciadas de maneiras diversas pelos quatro protagonistas: Lamis, Amira, Samir e Nicholas.

O encontro das personagens decorre de uma turbulência que perturba os passageiros, causando um primeiro contato marcado pela agitação que toma conta do avião. A aeronave, aqui, é apresentada como a perfeita metáfora para aproximação entre países e culturas, impulsionando os processos migratórios em todo o mundo. É ainda nessa cena que a autora retrata a diversidade da comunidade migrante árabe, por vezes retratada em veículos de comunicação e outros discursos de forma deturpada e com um viés homogeneizador, com vistas a apagar a multiculturalidade que se reflete no 'ser árabe'.

Em meio à turbulência que inquieta a todos, Amira, completamente apavorada, não cessa de fazer orações e clamar pela misericórdia de Deus. Nascida numa família marroquina pobre, muda-se para Londres ainda jovem, para trabalhar como empregada 
doméstica. Abusada sexualmente por um de seus patrões, começa a se questionar sobre o seu corpo, homens e riqueza, e então decide tornar-se prostituta de luxo, visando os membros da comunidade arabo-londrina.

Amira lembra-se exatamente quando decidiu vender a si mesma. Isso ocorreu quando o cozinheiro e o motorista do restaurante em que trabalhava tentaram pular em cima dela, como se ela fosse uma pomba. Mesmo antes disso. Quando o marido de sua tia agarrando sua mão com força, colocou-a em seu membro, insistindo que ela era sua esposa. Ele já havia obrigado-a a casar-se com ele sob a autoridade da cidade, já que o governo marroquino não voltou a emitir passaportes para as moças solteiras, pois a corrida para Europa parecia-se com a corrida de gafanhotos. Havia se esquecido também do rapaz do shawarma e do jardineiro da mesquita. Começou então a pensar seriamente na questão de seu corpo, os homens e a riqueza (pp. 248-249).

No decorrer da trama, ela decide se passar por uma princesa árabe e mobiliza um grupo de amigas, que finge ser sua consorte, a participar de todas as encenações que ela articula durante a narrativa, com intenções de conseguir mais dinheiro, porque acredita que os ganhos como prostituta não são suficientes para lhe garantir a estabilidade que buscou ao imigrar para Londres.

Amira preparou tudo para carregar o título de princesa. Precisava só animar-se. Indagou-se diversas vezes, fez chamadas nacionais e internacionais, gravou o dialeto dos seus clientes do Golfo. Ligou para consulados e escritórios perguntando coisas triviais para que ouvisse esta ou aquela palavra. 'O que é isto?', 'Não quero', 'Só quero...', 'Como vai?', 'Eu quero ir para...', 'Não gosto de você' (p. 199).

Sua maior artimanha decorre de uma simulação em um banco árabe, quando aplica um golpe em um senhor árabe que lhe oferece emprestadas 10 mil libras. O senhor, ansioso por ajudar, recebe como garantia somente a promessa de que o montante, enviado do seu reino e que ainda não havia chegado, seria devolvido na manhã seguinte, no luxuoso hotel Dorchester, onde estava hospedado. Valendo-se durante todo o romance de anedotas narradas para sustentar seu papel, Amira nos é apresentada por Al-Shaykh como uma Šahrazād dos tempos modernos, que, através de narrativas entrelaçadas uma à outra, vai ganhando tempo para sobreviver mais um dia na dura realidade londrina.

Contrapondo-se totalmente à personalidade de Amira, Lamis é o retrato da vulnerabilidade, insegurança e ansiedade. Iraquiana, da cidade de An-Najaf, vive toda sua infância com sua família, como refugiados na Síria e no Líbano. Aos dezessete anos, sua 
mãe arranja-lhe um casamento com um iraquiano rico que a leva para morar em Londres, onde se estabelecem e têm um filho. Recém divorciada, aos 30 anos, Lamis sofre com a possibilidade da liberdade que a sua nova vida lhe aponta, com a ausência do filho de 13 anos, que continua a morar com o pai, e a sensação de culpa frente a seus pais e amigas, pela decisão tomada. Embora tenha vivido por mais de uma década na capital britânica, a jovem sente que viveu todo esse tempo como prisioneira em um reduto árabe, submissa à tirania que sua sogra impunha a toda sua casa. Em decorrência dessa sensação de isolamento vivida durante tantos anos, assim que se divorcia e decide residir sozinha na capital britânica, dá início a uma tentativa de integração social pelo processo do aculturamento, assumindo um comportamento local, em detrimento de sua tradição de origem.

Desse modo, Lamis, por meio de aulas particulares de língua inglesa, tenta adquirir o dialeto londrino, opta por não comer mais comida árabe, por causa da sensação de acolhimento que ela proporciona, e esforça-se para ter um relacionamento aos moldes ocidentais com Nicolas.

Pega um lápis e uma caderneta na bolsa e escreve:

Este país se tornará meu país. Não viverei mais uma vida temporária.

Primeiro, acabei de chegar em Londres, e moro num hotel.

Segundo, procurar um apartamento para alugar.

(Risca o segundo item e escreve):

Segundo, aprender o sotaque britânico.

Terceiro, procurar trabalho, qualquer trabalho. Tenho que poupar dinheiro, usar o metrô ou ônibus ao invés de táxi para me locomover.

Quarto, fazer amigos ingleses.

Quinto, tenho que deixar este apartamento assim que possível.

Sexto, preciso parar de comer comida árabe. Não que eu coma alho e coentro e tema pelo meu hálito, mas porque a comida árabe me dá tranquilidade e segurança. Lembra-me dos dias da infância e de casa. (Inclina-se para pegar o celular e colocá-lo na cama. Após uma olhadela no espelho, apressa-se em adicionar à lista um sétimo item):

Sétimo, parar de usar kohl preto nos olhos (pp. 31-32).

Divergindo totalmente do caráter de ambas as personagens, Samir, o terceiro personagem árabe do romance, está sempre trajando uma indumentária de saltar aos olhos. Desde muito jovem, Samir se encantava com as roupas de sua mãe e as vestia escondido, até que um dia a senhora o flagrou usando sua camisola de náilon e seu batom vermelho e o internou em um manicômio. Mesmo tendo que se casar e constituir família, quando da guerra, usava sua identidade travesti, justificando-se à sua esposa que, ao 
caminhar entre os soldados vestido como mulher, não seria importunado e assim poderia ir e vir pela cidade sem se preocupar.

Foi necessário Deus desencadear uma guerra no Líbano para que as pessoas o deixassem em paz com sua reputação, e parassem de vigiar seus movimentos, e ele saísse de seu trabalho de descascador de batatas, no hotel. Fê-los perder a cabeça com questões de vida e morte para que Samir se vestisse como quisesse, justificando-se para sua esposa que se ele se cobrisse como uma mulher se livraria das barreiras de controle e compraria o pão mais rápido (pp. 218-219).

Samir deixou Beirute fugindo de sua esposa, cinco filhos e de sua fingida identidade heterossexual, pai amoroso e bom marido. Contrabandeando um macaco num cesto, de Dubai para Londres, Samir é trapaceado e obrigado a ficar com o animal, depois que os receptores fazem-no expelir os diamantes que o bicho trazia nas entranhas. Uma vez estabelecido na cidade, o libanês decide não voltar mais à Beirute, assume sua identidade homossexual e passa a flertar com os homens que conhece ao longo do romance.

O policial John estava investigando algo que inesperadamente obstruía o caminho na Edgward Road e causava um buzinaço entre os carros, quando a viu vestida com um manto marroquino, botas vermelhas, e um xale boá violeta, tentando cortar caminho por entre os carros, ziguezagueando, e rindo. Então comentou com o outro policial: "De onde vem essa bruxa?". Ouvindo essa palavra Samir lembrou-se da bruxa que monta na vassoura e voa, em seguida olhou para trás em direção ao policial, reprochando-o: Witch me? No say Ma Ma you boutiful policeman, you very boutiful I eccept go prison for you.

"Bruxa, eu? Haram ya mama, mas você, você é um policial muito lindo. Você é muito lindo, me prende e me põe na cadeia" (pp. 215-216)

Muito embora esses três personagens sejam originários de países diferentes e tenham vivenciado experiências completamente distintas, eles estão alinhavados pelo fio da imigração e da identidade árabe. Ao longo do romance, Al-Shaykh ilustra de diversas formas o peso de ser estrangeiro e o valor dado ao status de ser cidadão britânico, como no episódio em que Lamis pensa ter perdido seu passaporte no avião e, ao tê-lo de volta, sente-se como se a vida tivesse sido lhe devolvida.

Lamis, em seu íntimo, estava congelada de medo.... Seu valioso passaporte continuava desaparecido, muito embora a aeromoça tenha anunciado o seu sumiço mais de uma vez. 
Passados alguns momentos, Nicolas devolve a Lamis seu passaporte, assim que o vê no chão, sob o assento à sua frente. Ela o agradece como se ele lhe restituísse sua própria vida (p. 7).

O quarto e último protagonista é um inglês, fascinado pelo mundo árabe, que trabalha na Sotheby's e vive curtas estadas entre Londres e Omã. Nicholas é o personagem que se contrapõe a todos os estereótipos árabes. Por manter uma relação amorosa com Lamis, traz à tona os choques culturais e, através do contato com a alteridade, tenta traçar sua própria identidade cultural. Nessa tentativa, Al-Shaykh usa a voz do personagem britânico para dizer o que o inglês, em sua concepção, pensa acerca de si mesmo:

Sempre que tenho contato com outras culturas descubro o quão somos ingênuos. A verdade é que não conhecemos exatamente a situação política no Iraque. Toda vez que viajo percebo-nos como um povo estranho. Quando era criança pensava que éramos normais... mas agora sinto que os ingleses são introvertidos, tímidos e desprovidos de autoconfiança. Temos muitos tabus, os quais tentamos evitar: riqueza, sexo, religião... (pp. 236-237).

Especialista em artefatos orientais, Nicolas demonstra durante todo o romance, em seu relacionamento com Lamis, que, embora tenha um conhecimento considerável sobre a arte das adagas omanis, desconhece completamente a realidade dos povos árabes, bem como as restrições impostas a uma mulher que vive sob a tradição islâmica. Isso fica claro na sua insistência de levar consigo Lamis numa de suas viagens ao Omã. Apesar de toda a explicação dada pela moça, ele não entende todas as complicações nas quais a jovem estaria envolvida ao se hospedar em um hotel, em um país do Golfo - região bastante conhecida pelo conservadorismo religioso - com um homem ocidental solteiro, sendo ela árabe de origem muçulmana.

"Okay, você não precisa vir morar comigo agora. Eu sei que meu apartamento é extremamente pequeno, mas vamos viajar juntos para o Omã, por um ou dois meses."

"Omã? Impossível que eu vá com você para o Omã."

"Juro que você verá lá mil e quinhentas estrelas ao invés das quinhentas em Londres."

"Posso imaginá-las."

"Não posso adiar mais minha viagem. Preciso ir por alguns dias."

"De todo modo, não podemos ficar juntos."

"Por que? Você não é inglesa, portadora de um passaporte inglês? Ahhh entendi... A lei omani proíbe a entrada de inglesas solteiras menores de 35 ou 40 anos, exceto que se casem com omanis."

Estava a ponto de respirar aliviada. O Sultão Qaboos salvou-a! 
"Estou brincando, Lamis!"

"Mas nós não somos casados!"

"Não importa, você é inglesa."

"Mas o meu nome, escrito no passaporte, é árabe. E o local do meu nascimento é Najaf - Iraque."

"Okay, reservamos dois quartos no hotel, você é minha convidada, eu não me importo de gastar tudo o que tenho com você."

Nicolas pingava felicidade e confiança porque não lhe restava nenhum pretexto.

"Nicolas, por favor, pare de sorrir. Eu que conheço o regime árabe, não você. [...]" (pp. 278-279).

Um outro aspecto também explorado pela autora, através da relação dos dois personagens, é a questão da disparidade das realidades vividas por Lamis e Nicolas durante sua infância e adolescência. Enquanto Lamis narra sua trajetória na condição de refugiada migrando de um país a outro, e, posteriormente, submetida a um casamento forçado, é questionada pelo parceiro sobre a razão de ter se casado ao invés de fugir. Como um contraponto a sua narrativa, Nicolas compartilha com a moça que, ao terminar os estudos e ainda indeciso sobre o futuro, decidiu colocar a mochila nas costas e desbravar o mundo que desconhecia: o Oriente. Assim, ele relata sua experiência para Lamis, revelando todo o deslumbramento dos dias em que viveu na Índia.

"Tudo bem, você me entendeu mal. Eu sinto muito por você ter se casado tão jovem, isto é tudo. Enquanto eu viajava ao redor do mundo sem qualquer responsabilidade. Na idade em que você se casou, eu estava visitando a Índia sozinho com poucas rúpias, e minha mochila nas costas. Eu tento entender a razão de não ter tentado encontrar um trabalho depois de me formar... Seria preguiça? Ou eu realmente não sabia o que eu queria ser..."

"Parece que você descobriu..."

"Não foi sozinho, pois, sempre que tentei pensar sobre o assunto, eu me aterrorizava. Mas o acaso decidiu por mim e encontrou um trabalho para mim" (p.146).

Dispensa comentar que esse relacionamento, que figura a relação OrienteOcidente, está fadado aos constantes conflitos e a discussões que causam desconfortos e choques culturais. Não obstante utilizem o mesmo idioma, fica claro nos diálogos entre os personagens que eles não falam a mesma língua. As recorrentes incompreensões das diferentes realidades tornam o relacionamento cada vez mais insustentável. As hesitações de Lamis em aceitar viver com Nicolas e a dificuldade do parceiro de entender as 
tradições impostas à moça por pertencer a uma família muçulmana, ser divorciada e ter um filho que vive com o pai, impulsionam a ruptura da relação.

Nesse quadro de Al-Shaykh, Londres dá a cada uma dessas personagens a liberdade que procuram para completar a si mesmos e emancipar-se da censura, seja ela social, religiosa, política ou sexual. A censura que restringe cada um de seus movimentos e pensamentos em sua terra natal.

Londres os liberta de tudo isso. E é desse cabo-de-guerra entre as inibições internas de seu país de origem e a sensação de libertação que experienciam em Londres que emergem os dramas e comédias suscitados no romance (EL-ENANY, 2006, p. 198). ${ }^{16}$

Já de início, percebemos que a autora trabalha a cidade de Londres com duas noções espaciais completamente conectadas. Na primeira, o espaço integra "os componentes físicos que servem de cenário no desenrolar da ação e para a movimentação dos personagens", e na segunda, "o conceito de espaço pode ser entendido em sentido translato, abarcando então tanto as atmosferas sociais (espaço social) como até psicológicas (espaço psicológico)" (C. Reis; A.C.M. Lopes, Dicionário de Teoria da Narrativa, p. 204 apud BRANDÃO, 2013, p. 50).

Nesse sentido, seria de grande importância observar o 'tratamento' que é concedido ao espaço para melhor compreensão da obra. Longe de ser apenas ambiente para o desenrolar da narrativa, a Londres é, o tempo todo, atribuído um status de personagem.

Como ocorreu de ela não conhecer um inglês sequer para que tomasse com ele um chá ou uma cerveja? Indubitavelmente, os ingleses permaneciam proibidos para ela, assim como a cidade. Os lugares são pessoas, e as pessoas com as quais ela tinha uma relação direta eram a cantora, alguns médicos e o general (p. 24).

Observa-se que, desde as primeiras representações propostas, tem-se uma cidade definida a partir do aprofundamento das questões e experiências do sujeito. Por isso, a cada descrição, novas características são elencadas, dando uma diferente perspectiva com relação à metrópole. Londres não é espaço meramente físico, reduzido à função de

\footnotetext{
16 "London liberates them from all that. And it is from the tug-of-war between internal, homegrown inhibitions and the sense of release they experience in London that the dramas and comedies of the novel arise."
} 
trânsito de suas personagens: é um espaço social e, por ser trazida ao texto com tanta riqueza de detalhes, nos parece uma personagem, que funciona como mediadora das relações entre os demais personagens do romance, conectando todos eles, apesar de suas disparidades.

Diante do quadro apresentado por Al-Shaykh no romance em tela, percebemos que o questionamento levantado por Larson (1991, p. 17) se torna plausível novamente: para quem foi escrito Innahā London ya 'azīzì? Para os londrinos? Para a comunidade árabe residente na capital britânica? Para os árabes que vivem em sua terra natal ou ainda para uma comunidade alheia às envolvidas na trama?

Esses questionamentos tornam-se extremamente relevantes, levando em consideração o contexto de produção da obra, uma narrativa composta em língua árabe, publicada no Líbano, mas que fala diretamente sobre um universo bem desconhecido pela comunidade árabe, permeado de referências a locais e particularidades que só quem esteve em Londres conseguiria compreender. Mesmo sua tradução ao inglês traz consigo referências da comunidade árabe local que também não são acessíveis aos anglófonos que não têm contato com esse grupo imigrante.

Cabe aqui mencionar que, por conta da complexidade de suas referências e da maneira em que está estruturada a sua narrativa, esse texto sofreu duras críticas na comunidade árabe, que colocou em questão a legitimidade das relações entre os personagens, a sua presença na capital britânica, bem como a qualidade do enredo em termos composicionais, sob argumentos pouco sólidos.

El-Youssef (2004) reclama a falta de unidade do texto de Hanan Al-Shaykh, bem como a fragmentação da estruturação da narrativa e ausência de uma razão orgânica que conecte os personagens. Sua crítica se deve ao fato de o romance estar dividido em nove capítulos, dentro dos quais há entre três e quatro subdivisões, nas quais cada um dos personagens protagoniza suas histórias individuais. Os desdobramentos dos episódios não operam segundo uma ordem cronológica rígida, embora em vários trechos haja uma ideia de sucessão de eventos. À medida que esses personagens se relacionam com a cidade, as casualidades cotidianas encarregam-se de reuni-los em momentos inesperados.

El-Youssef (2004) contesta severamente as relações díspares entre os personagens, como por exemplo o relacionamento amoroso de Lamis e Nicolas, que teve início por causa de um encontro casual no Lord Leighton House, pouco tempo depois de 
se conhecerem no episódio do avião, além de sua aproximação com Amira, cujas afinidades partilhadas com a moça resumem-se em ser imigrante árabe e viver em Londres.

Questionando os encontros que se dão por acaso ao longo do romance - como se essas casualidades e amizades envolvendo personalidades díspares não se dessem na vida real -, El-Youssef descreve como retrato da inverossimilhança as relações estabelecidas no enredo, de modo que a ficção tivesse por finalidade reproduzir a realidade fielmente a nível documental, e todas as relações humanas na vida real seguissem um determinado padrão, não havendo espaço para as imprevisibilidades que guarda o dia-a-dia de quem vive numa grande metrópole como Londres.

No entanto, se voltarmos os olhos ao que propõe a autora no texto, de fato, o elo que traz unidade à obra é o desterro e a própria cidade de Londres. Nesse caso, o espaço e as relações que os personagens estabelecem com ele fariam as conexões necessárias para a compreensão total do romance.

Espaço é sinônimo de simultaneidade, e é por meio desta que se atinge a totalidade da obra. Em tais abordagens, o desdobramento lugar/espaço se projeta no próprio entendimento do que é a obra. Por um lado, a obra é constituída de partes autônomas, concretamente delimitadas, mas que podem estabelecer articulações entre si - segundo, pois, uma concepção relacional de espaço. Por outro, exige-se a interação entre todas as partes, algo que lhe conceda unidade, a qual só pode se dar em um espaço total, absoluto e abstrato, que é o espaço da obra (BRANDÃO, 2013, p. 62).

Deste modo, Londres, ao receber um tratamento que lhe dá status de personagem, passa a elencar os demais protagonistas, provocando seus encontros fortuitos no decorrer da narrativa, alinhavando as histórias autônomas consigo mesma, e, de maneira geral, entre si, dando um acabamento e uma totalidade à obra.

Quando questionada a respeito da motivação para a criação dos personagens, AlShaykh (2003) justifica sua existência argumentando que estas lhe serviram como veículo para dizer tudo o que pensava sobre a sociedade árabe na Inglaterra, precisamente. Não obstante a grande importância por ela atribuída a cada personalidade desenvolvida, a própria cidade foi construída na narrativa de modo que se transformasse numa personagem, basta perceber que lugares ocupam um espaço de bastante relevância em sua literatura. Isso devido ao modo como os lugares moldam a vida de seus personagens e como os personagens dão um novo caráter ao lugar. E o lugar, nas próprias palavras Al- 
Shaykh (2016), "é como um personagem, tem experiências, leis e fundamentos próprio, e influencia e é influenciado por tudo que o rodeia" ${ }^{\prime 7}$.

Por causa dessa vida que os espaços possuem, Hanan Al-Shaykh (2003) relata que levou alguns anos até que sentisse a liberdade necessária para escrever sobre Londres. Mesmo vivendo na cidade durante um longo tempo, a escritora não se sentia envolvida com o lugar, de modo que a cidade lhe parecia inacessível, e ainda que tenha escrito peças teatrais ${ }^{18}$ sobre imigrantes em Londres, foram necessárias duas décadas para familiarizarse e escrever sobre, ou talvez, para a cidade.

Nesse longo período de residência na capital britânica, inconscientemente a escritora pensa sobre como Londres recebeu e ainda recebe milhares de imigrantes, tentando entender as razões que levaram essas pessoas à diáspora, se fatores econômicos ou políticos. A presença desses indivíduos na cidade é um pote cheio de ingredientes, os quais estimularam sua imaginação durante todo esse tempo em que conjecturava incansavelmente os motivos que os fizeram sair de seus países de origem, mudar radicalmente suas vidas, e ainda se conseguiriam, ou por quanto tempo conseguiriam continuar na Inglaterra.

A permanência desses indivíduos nessa metrópole, segundo Al-Shaykh (2003), provoca mudanças, tanto no espaço como no sujeito. Não importando o quanto intencionem se manter fiéis às tradições, essas pessoas sempre se transformarão, na medida em que o indivíduo também é transformado e, via de regra, eles se tornam ou mais fanáticos ou mais liberais. Mas, para todos os efeitos, eles se transformam. Há uma transferência mútua cultural, fruto da interação das pessoas umas com as outras, que atribui um caráter diferente à cidade e aos próprios sujeitos dessa interação.

$\mathrm{Na}$ medida em que inseria elementos da cidade britânica em sua narrativa, a escritora se dava conta da importância que tinham para ela.

Porque quando eu, por exemplo, escrevi sobre a Oxford Street ou a BT Tower, é como se eu estivesse dizendo para mim mesma, de certo modo, essas coisas significam muito para mim. Escrever sobre

17 Trad:

$$
\text { , لأن المكان هو كالشخصية لها تجاربها وقو انينها وأسسها، تؤثر وتتأثر بما يدور حولها .، }
$$

18 As referidas peças teatrais são "Paper Husband”, de1997, e "Dark Afternoon Tea”, de 1995, ambas representadas no Hampstead Theatre (London), e também colocam em pauta a questão da relação Oriente-Ocidente através da temática da imigração. 
elas significa que eu penso sobre elas também. Eu as sentia. Agora eu realmente posso escrever sobre elas, não como antes, quando você é apenas um estranho na cidade. Quando você escreve sobre Oxford Street, não tem o mesmo significado quando você mora em Londres e quando você sabe o que Oxford Street significa (AL-SHAYKH, 2003). ${ }^{19}$

Embora tenha vivido por tanto tempo fora do Líbano sob influência ocidental, a escritora não sabe dizer se a diáspora influenciou de forma direta a estética de sua literatura. Consciente de que o ser humano está sempre em constantes mudanças, AlShaykh (2003) diz não saber discernir se elas advêm do envelhecimento ou da sua presença em território estrangeiro.

A longa exposição a literaturas internacionais e o contato com escritores nãoárabes proporcionaram-lhe experiências que a autora não teria se estivesse residindo em Beirute. Ao examinar a literatura de seus pares, Al-Shaykh (2003) observa que no Oriente Médio, mas sobretudo no mundo árabe, quando se inicia uma narrativa com um tom sério, esse texto terá de segui-lo até o fim, não se pode deixar uma só sentença que transpareça o cômico ou qualquer tipo de humor. Segundo a autora, não se pode misturar as coisas de maneira alguma. No entanto, sua estada na Inglaterra e o contato com a literatura no país fê-la perceber que para os Ocidentais você é considerado muito mais habilidoso se consegue transitar entre o cômico e o trágico, haja vista que, principalmente para escritores oriundos de países do terceiro mundo, é muito mais fácil produzir o choro que despertar o riso.

O fato é que, quando olhamos diretamente para o texto de Innahā London ya 'azīzì, talvez por conta da própria temática da obra, vemos um texto completamente contagiado por anglicismos e pela cultura ocidental. Despertando o cômico da realidade trágica de suas personagens, Al-Shaykh parece então ter sido bastante influenciada pelo modelo da literatura ocidental. E, embora os críticos que leram a tradução da obra para a língua inglesa pontuem o seu tom humorístico, a autora insiste em reforçar que Innahā

\footnotetext{
19 "Because when I, for example, wrote about Oxford Street or the BT tower, it's as if I'm saying to myself, in a way, these things mean something to me. To write about them, it means, that I thought about them. I felt them. Now I can really write about them, not like before, when you're just in a strange city. When you write about Oxford Street, it doesn't have the same meaning as when you live in London and you know what Oxford Street means."
} 
London ya 'azīzì não é uma narrativa meramente cômica, servindo apenas ao entretenimento, simplesmente porque trata de questões seríssimas.

Não obstante seu tom de leveza, a narrativa expressa de forma clara a miserabilidade de seus protagonistas e a condição esquizofrênica em que vivem na diáspora. Em constante conflito consigo mesmo, esses indivíduos estão sempre tendo que negociar entre a tradição da cultura de origem e a cultura local.

Através desse romance, Hanan Al-Shaykh parece ter por objetivo promover um encontro de realidades completamente distantes unidas pela diáspora no Ocidente, e apresentar Londres ao indivíduo árabe, bem como introduzir a essa cidade os árabes que habitam seus espaços, contagiando-a com sua cultura, cor, língua e gastronomia. A narrativa de Innahā London ya 'azīzī e, posteriormente sua tradução para o inglês, Only in London (2002), funcionam como uma ponte que une dois lados de uma mesma cidade cortada por um imenso rio que, aparentemente, seria instransponível, e que mantém essas comunidades fechadas em seus espaços, que parecem inacessíveis.

Ao intitular sua obra Innahā London ya 'azīzì, a autora estaria apresentando tanto aos londrinos como aos árabes o que realmente ela pensa ser essa cidade, tão marcada pela presença árabe, mas tão desconhecida dos árabes, que parecem nutrir uma ilusão sobre o que ela é. Considerando que a própria cidade é uma personagem, quem de fato é essa grande metrópole e o que ela pensa sobre essa comunidade estranha que invadiu seus espaços, obrigando-lhe a conviver com o Outro que, por muito tempo, era acessível apenas discursivamente? Se, por meio de suas personagens árabes a escritora diz aquilo que pensa sobre Londres, nos parece que através de seus personagens ingleses ela emula o discurso que acredita que essa comunidade tenha com relação à sua contraparte.

Assim que publicada a tradução para língua inglesa, Only in London (2002), a crítica britânica contestou o fato de o romance ter sido escrito em língua árabe e não em inglês, pois a narrativa parecia-lhes ser dirigida a um público leitor inglês, muito embora nem sua tradutora entendesse claramente todas as referências culturais contidas no texto. Promovendo o encontro de dois desconhecidos, Al-Shaykh (2003) assume que foi questionada tanto por seu tradutor no que diz respeito às referências a elementos da tradição arabo-islâmica, por exemplo a 'ašūra, assim como pelo editor do texto em árabe, que argumentou serem os lugares mencionados no texto - como BT Tower e a tão famosa Oxford Street - completamente ignorados pela comunidade do mundo árabe. Mesmo 
ocupando uma posição de mediadora intercultural ela respondeu: "Bem, que eles pesquisem!"20, ou seja, que eles se descubram, que se encontrem.

20 "Well, let them search!" 


\section{CAPÍTULO 2}

\section{A emergência das romancistas e a literatura árabe pós-colonial em tradução}

Este capítulo foi pensado de modo a delinear um panorama do processo histórico de desenvolvimento do gênero literário que marcou a modernidade árabe, o romance. Desse processo destacamos a emergência das romancistas, a importância do romance póscolonial, sua tradução e recepção no Ocidente. Tudo isto, para oferecer ao leitor o pano de fundo no qual se inserem as obras de Al-Shaykh, em especial Innahā London ya 'azīz $\bar{l}$ 'É Londres, meu caro', bem como, de que tradição literária a escritora descende, pois entendemos que é importante conhecer com quem ele dialoga e reconhecer as suas referências, para melhor compreensão do trabalho de um autor e sua tradução.

A historiografia da tradição de tradução literária diz respeito em muito à história dessa literatura, não só em termos da relação que as obras do corpus nativo estabelecem entre si, mas em relação aos textos estrangeiros que passam a integrar seu sistema literário. E a tradução na história da literatura árabe moderna tem um papel de grande importância, pois resulta no processo de introdução do gênero romance no sistema literário árabe. De modo que, ignorar a recepção da literatura traduzida na história da literatura árabe é ignorar um dos maiores e mais importantes processos de modernização cultural ocorridos na história dos povos árabes.

Quando estudamos a emergência do gênero nesse sistema, estamos indiretamente também fazendo um estudo da historiografia da tradução no contexto árabe. Pois não há como entender um processo sem ao menos elucidar o outro, e quando pensamos em escrever um trabalho de tradução de literatura árabe, torna-se bastante relevante aprofundarmo-nos no assunto, para melhor entender as problemáticas envolvidas na prática. E tratar da emergência do romance no mundo árabe é também falar do processo de modernização ocorrido entre o final do século XIX e início do século XX.

O romance árabe, por assim dizer, nasceu da interação entre duas culturas, durante uma fase muito específica na história do mundo árabe, caracterizada pela hegemonia europeia, esforços de reforma e a desintegração do Império Otomano. De certa maneira, a emergência do gênero foi o resultado de uma longa e extensa crise social e da consciência de que o mundo havia mudado radicalmente. 
A complexidade em se discutir essa temática reside, principalmente, no fato de que a designação 'mundo árabe' abrange uma região geográfica bastante extensa, permeada por multiculturalidade e diversas identidades guardadas no reconhecimento de 'ser árabe'. A parte disso, o momento histórico em que se deu esse processo de modernização literária é marcado por diversos conflitos de natureza política, religiosa, identitária e social, a nível externo e interno, o que cria uma atmosfera nebulosa no processo de delimitação cronológica e espacial.

A própria bibliografia que se dedica à descrição sobre o desenvolvimento do gênero no contexto árabe apresenta uma polifonia ao dispor de informações que caracterizam o período. Isso porque há uma eclosão de escritores nas três principais regiões culturais do Oriente Médio dessa época: Cairo, Damasco e Beirute. Além da disputa entre os partidários das duas principais correntes literárias da época, os tradicionalistas e os modernistas, o que influencia diretamente na classificação das obras desse período inicial, uma vez que cada uma das vertentes considera com diferentes graus de relevância os vários parâmetros que caracterizam o gênero emergente.

O processo de tradução de literatura europeia para a língua árabe, no período da Nahdah (Renascimento Cultural Árabe), com vistas a criar um conjunto de obras que serviria de modelo de narrativas do gênero romance, é comumente analisado pela perspectiva orientalista, e, segundo Van Leeuwen (2004), a influência dessas traduções, em muitas áreas, deu origem a um tipo de cultura esquizofrênica, na qual a elite intelectual foi formada por visões estrangeiras e ficou separada do tradicional corpus nativo do conhecimento.

À parte de toda essa celeuma que dividia os intelectuais, há ainda uma negligência com relação às obras produzidas por escritoras árabes cuja data de publicação coincide com esse período inicial e que partilham dos parâmetros estabelecidos para definição do texto literário do gênero romance, como Husn Awāqib: Ġāda Az-Zahrah 'Boas consequências: $\dot{G} \bar{a} d a$, a flor' de Zaynab Fawāz, de 1899. Bem como outros que atribuem a inauguração do romance a textos considerados por outros teóricos gêneros de transição, como Hadīt '̇̃sa ’ibn Hišām, de Muhammad Al-Muwaylihi, publicado só em 1907.

Orientado por M. M. Badawi, Roger Allen estudou durante seu doutorado o Hadịt 'I $\bar{s} a$ 'ibn Hišâm, publicado primeiramente seriado no jornal de sua família e, em 
1907, na forma de livro. O crítico defende que este seria um texto de transição, cuja função no sistema literário seria de fazer a ponte entre o gênero nativo clássico da maqāmāt e o romance nativo árabe. A obra refletiria uma adesão de princípios da narrativa árabe pré-moderna e, por isso, faria jus ao título de grande pioneiro dos trabalhos de narrativa árabe moderna.

Questionando o que foi Nahḍh, quem e quando se decidiu que este seria um marco para o Renascimento Cultural Árabe, o autor pontua que a obra de Muwaylihi é a primeira a voltar à tradição e dar continuidade a ela, e relata que o texto teria surgido após o autor passar um longo período na Europa e com os otomanos em Istambul, decidindo escrever uma narrativa fundamentada no seu tempo. Allen ainda aponta que Jurji Zaydān, autor da vanguarda libanesa, cuja obra também é considerada seminal, tinha um projeto de simplificar o estilo literário árabe, utilizando-se de uma forma moderna para falar de história antiga, enquanto Muwaylihi se vale de uma forma antiga para tratar de eventos contemporâneos (ALLEN, 2015).

A tradição da ficção na literatura árabe moderna, segundo a grande maioria dos teóricos, teve início a partir do período de renascimento e assimilação cultural conhecido, em língua árabe, como Nahḍh (Renascença Árabe). Esse desenvolvimento criativo, que principiou no final do século XIX, era movido por duas forças separadas; de um lado, o processo de retorno às fontes da tradição literária árabe, daí a emergência de um movimento 'neoclássico'; e de outro, o processo de tradução dos trabalhos europeus de ficção para a língua árabe, como forma de fomentar, pela mimetização, o surgimento de uma ficção árabe moderna nativa (ALLEN, R. 1992, p. 180).

De acordo com Adonis (2003, p. 77), o processo de modernização literária na sociedade árabe transcende o campo das artes e apresenta-se como indicativo de uma crise cultural geral, que é, de algum modo, uma crise de identidade. Esta crise estaria ligada tanto a uma luta de poder interno, que tem variados aspectos e opera em diversos níveis, quanto a um conflito externo contra os poderes estrangeiros. Aparentemente, o retorno aos ancestrais, ao longo da história árabe, tem sido mais avidamente perseguido sempre que o conflito interno se intensifica ou o perigo externo se torna mais agudo.

Al-Mahrooqi \& Denman (2016, p. 13) admitem a dificuldade em delimitar e compreender o conceito de identidade, sobretudo pela sua natureza mais disposta ao 
dinamismo que ao estado estático. Por se tratar de uma construção contínua, a identidade é resultado de experiências passadas, presentes e futuras, e sua base está nas experiências de vida individual. Uma miríade de fatores interage para "construir e interpretar o processo de identificação" 21 e, esse ato, para formar o nosso senso de afiliação, seja consciente ou inconscientemente. Por essa razão, a identidade não está inteiramente sob o controle de um único indivíduo, mas deve, em certo grau, depender das percepções de outros - se esta identidade é posta sobre uma pessoa por outra, ou se essa pessoa busca o reconhecimento de sua identidade pelos outros.

Por esse motivo, identidade depende muito do contexto e de circunstâncias socioeconômicas, e é "construída e transformada em relação ao poder, tanto dentro do eu quanto em relação à comunidade" ${ }^{22}$. No que tange à circunstância socioeconômica, a busca pela modernidade por todo mundo árabe teve importantes ramificações para o discurso de identidade "árabe". O colonialismo afetou as sociedades árabes na medida em que poderes europeus buscavam moldar essas sociedades em imagens que eles desejavam, para o propósito de servir seus interesses estratégico, econômico e político (HUGHES, 2011; SAID, 1978 apud AL-MAHROOQI, R.; DENMAN, C., 2016: 13).

Talvez isto ajude a explicar por que a modernidade atual na sociedade árabe, às vezes, flui fortemente - como no caso dos séculos VIII, IX e $\mathrm{X}^{23}$ - e outras vezes diminui e retrocede - como ocorreu nos séculos seguintes -, dependendo se ambos os conflitos, interno e externo, estão no ponto alto ou baixo. Também pode-se explicar por que a modernidade tende a ser uma força que rejeita, questiona e provoca, sem entrar de qualquer modo consciente e radical na estrutura da mente árabe ou na vida árabe como

\footnotetext{
21 "construct and construe the process of identification"

22 "constructed and transformed in relation to power both within the self and in relation to the community"

${ }^{23}$ Adonis, na referida obra, faz uma extensa comparação entre o que foi considerado, nos séculos VIII, IX e X, um momento de modernização da cultura árabe, no início da Hégira, e as mudanças que ocorreram durante o século XIX e XX no mundo árabe. O autor propõe que só alcançaremos um entendimento adequado sobre a poética da modernidade árabe se a observarmos através do contexto social, cultural e político. Ele entende que o desenvolvimento desse processo de modernização ocorrido no século VIII, assim como o que se iniciou no fim do século XIX, estava totalmente atrelado aos movimentos revolucionários que exigiam igualdade, justiça e um fim para a discriminação entre muçulmanos por motivos de raça e cor. Estava também mais ligado com os movimentos intelectuais comprometidos com a reavaliação das ideias e crenças tradicionais, especialmente na área da religião (ADONIS, 2003, pp. 73-74).
} 
um todo. Talvez, finalmente, isso possa ser um meio de elucidar o domínio da mentalidade tradicionalista na vida árabe e na poética e pensamento árabes.

No período da Nahdah, que também coincide com o período do colonialismo ocidental e do contato maior com essa cultura e sua modernidade, opiniões ficaram divididas em duas grandes tendências: a tendência tradicionalista/ conformista (uṣūlì), que considerou a religião e a linguística árabe ciências de sua base principal; e a tendência transgressora/ não-conformista (tajāwuz $\vec{l})$, que via sua base, em oposição, no secularismo europeu (ADONIS, 2003).

Essas tendências, segundo Allen (1992), durante a fase inicial, apresentavam-se em situação de confronto, sob as rubricas de 'tradicional' e 'moderno'. No caso da ficção, esse processo de renascimento envolvia a investigação das tradições antigas da prosa árabe na busca de modelos. E, para surpresa da audiência ocidental, que consideraria $A s$ mil e uma noites como um repositório de narrativas, durante esse exame dos textos da herança tradicional, as histórias contidas nesta obra foram reputadas como um recurso bastante parco em termos de estilo, sendo atribuído a elas o status de gênero da cultura popular e, portanto, não faziam parte do repertório a ser examinado.

Adonis (2003) caracteriza esse período, sobretudo, por uma quebra na vida árabe - na teoria e na prática. Por um lado, foi a revitalização tradicional de formas expressivas que haviam surgido em épocas passadas para examinar problemas e experiências atuais. Por outro lado, havia no Renascimento uma dependência do Ocidente: com relação ao passado, desviava-se o árabe da prática criadora, através do procedimento de recuperação e recordação; em se tratando do Ocidente euro-americano, ao substituir a falta de criatividade pela adaptação intelectual e empréstimos técnicos. O fato é que a cultura árabe dominante é resultante, na maioria de suas facetas teóricas, do passado, sobretudo religioso, enquanto a maior parte de seus aspectos técnicos, do Ocidente euro-americano.

Segundo o que afirma Allen (1992, p. 180), os textos nativos que teriam servido como fonte para a criação de um novo repertório literário autêntico seriam as maqāmāt, um gênero literário em prosa que floresceu na tradição completamente retoricada de crítica, em que havia uma combinação de aspectos do picaresco evidente na relação entre narrador e 'herói'. Mas o próprio autor assume que, de fato, isso ainda é tema de debate. 
Porém, em seu texto The beginnings of the Arabic Novel (1993) que trata da gênese do romance no mundo árabe, parece que o autor segue um viés da tradição neoclassicista no processo de descrição dos trabalhos que foram considerados embriões do que depois se estabeleceria como gênero romance de fato, mencionando superficialmente os autores que seguiram pela linha da tradução, adaptação de textos europeus, e ignorando completamente todos os trabalhos paralelos produzidos pelas escritoras árabes pioneiras que se concentravam no centro cultural do mundo árabe, o Egito.

O fim dos anos 1880 foi um momento de grande agitação no Egito, pois havia um clima de abertura e recepção do novo. O país atraía os grandes intelectuais árabes de então, inclusive mulheres, como as libanesas Zaynab Fawwāz (1850-1914), Wardah alYazìjī (1838-1924) e a palestino-libanesa Mayy Ziyadah (1886-1941), que não encontravam em seu país natal tamanha liberdade intelectual (COOKE, 2005, p. 443).

Apesar dessa migração das escritoras ao Egito em busca de maior liberdade de expressão, Al-'Ida (2008, p. 14) observa que Beirute, estando bem situada geograficamente, funcionava como uma conexão entre o Oriente e o Ocidente, um espaço livre para o diálogo cultural, aberto para receber o Ocidente e a influência de sua civilização racionalista. A autora ainda afirma que, com a intensificação do conflito sectário dos cristãos-drusos no Monte Líbano, nos anos 1840, e os massacres ocorridos em 1860, houve um aumento significativo de comunidades estrangeiras em Beirute, consulados ocidentais e as escolas missionárias realocaram-se na região. Foram nessas escolas estrangeiras e religiosas onde a maioria das escritoras pioneiras foi educada.

No entanto, a natureza cristã da educação das missões estrangeiras significava que muçulmanos esclarecidos que desejavam e podiam educar suas filhas evitavam mandálas para essas escolas, temendo a retaliação dos demais, que os acusariam de blasfêmia e poderiam humilhá-las ou até mesmo prejudicá-las (AL-'IDA, 2008, p. 14).

As mulheres desse círculo, em sua maior parte, pertenciam à classe média e estavam em contato, mesmo que indiretamente, com europeus. Elas tinham capacidade de se comparar com sua contraparte europeia e reconhecer contrastes: a sociedade europeia recebia as mulheres na esfera pública. Elas estavam conscientes de que, apesar de gozarem de privilégios econômicos, não desfrutavam de liberdade no âmbito social. A 
exclusão e opressão sofrida permeavam todas as classes sociais, e por causa disso sua expressão literária espelhava a experiência dos outros e a reflexão fomentava a emergência da consciência da injustiça que sofriam por causa do gênero (COOKE, 2005, p. 443).

Essas escritoras árabes de vanguarda foram influenciadas tanto pela literatura árabe clássica como pelas traduções de escritos europeus aos quais estavam sendo expostas. Nesse período, elas geralmente escreviam numa variedade do árabe nãovernáculo, com a intenção de afirmar sua intelectualidade, tão subestimada pela sociedade da época. Lançando mão de uma rica e complexa tradição, produziam textos que abrangiam as figuras do recitador de poesias sobre o amor divino; a princesa que possuía saber, poder e reputação; a menina escrava treinada no alaúde para satisfazer seu mestre; a mulher forte que tinha habilidade e eloquência para o discurso público, que transitava entre o audacioso e até mesmo o obsceno; mas contemplava também a mulher tímida que fala em baixa voz por detrás das cortinas (ASHOUR et al., 2009, p. 15 apud ALMAHROOQI, R. \& DENMAN, C., 2016, p. 10).

Ashour et al. (2009) afirmam que essa tradição das escritoras árabes remontaria à Šahrazād, a amante do discurso, narradora de histórias que engendram em si mesmas outras histórias. Fábulas que transcendem o tempo e o espaço, através das quais ela abandona o rei e seus aposentos para penetrar num universo maior. Por essa razão, tornase impossível tratar da emergência das escritoras no mundo árabe sem ao menos mencionar essa figura cujo potencial impactou não apenas o Oriente, mas invadiu o Ocidente, causando transformações no imaginário cultural também dos povos que recebiam esse repositório de narrativas através das traduções.

O legado de Šahrazād no imaginário cultural árabe é de uma heroína que salvou todo um reino das mãos de um monarca tirano através do encadeamento contínuo de suas narrativas estonteantes; ao narrar, ela também ajudou a salvar o sultão, fazendo-o perceber a perversidade de suas ações e restaurando sua fé na humanidade. As mil e uma noites, como entretenimento e atividade educativa, cumpre um papel muito importante na vida da mulher, pois Šahrazād demonstrou a homens e mulheres o poder da narrativa e os seus efeitos sobre toda a sociedade. No prólogo moldura, a heroína impediu o massacre de centenas, senão milhares, de mulheres por meio de sua arte audaciosa na manipulação 
da palavra. Indiretamente, embora de maneira significante, a palavra protege não só a mulher, mas todo o tecido social da violência de um déspota.

É com essa personagem em mente que se olha para as primeiras romancistas árabes, que encontraram nesse gênero uma maneira de influenciar as mentes e os corações de seus leitores, bem como entretê-los. Interessantemente, as mulheres, tanto as que escrevem esses textos como as que nele são representadas, são importantes componentes da sociedade da qual fazem parte. Elas entendem o funcionamento do jogo político, tomam posições firmes, falam abertamente e com convicção e gozam de um certo grau de independência. Por cobrirem um vasto campo de tópicos sociais e comprometimento com as reformas sociais, os trabalhos por elas produzidos revelam grande habilidade literária (COOKE, 2005, p. 446).

No discurso literário, afirma Cooke (2005, p. 446), reverberam questões que reformadores sociais estavam fazendo na época, tais como o motivo para que mulheres fossem privadas da educação e do mercado de trabalho. Seria só o gênero uma justificativa plausível? Indagavam ainda os efeitos da invisibilidade feminina no tecido social. $\mathrm{O}$ fato de escreverem e serem publicadas era uma forma de negação ao isolamento a que foram condenadas. "Elas estavam recusando a crença de que a voz das mulheres são 'awrah, 'uma vergonha e desonra'." 24

$\mathrm{O}$ ato da escrita funcionava como uma válvula de escape do papel de gênero determinado, muito embora não parecesse. Autoras como At-Taymūryyah, Fawwāz, Bāḥițat al-Bādiya e Karam desafiaram o patriarcado e advogaram reformas no, até então, intocável espaço doméstico. No entanto, isso só foi possível porque elas se colocaram nos limites dos dois mundos, construindo pontes que, inicialmente, poucos decidiram cruzar.

Considerado um amplificador para a difusão do seu discurso, o jornalismo foi um espaço bastante utilizado pelas escritoras na manifestação de suas demandas e, também por isso, teve um papel importantíssimo na renascença da literatura árabe, no Egito e no Líbano. Surgindo com maior difusão em meados do século XIX, a publicação de noticiários aumentou rapidamente em número no século $\mathrm{XX}$, foi um veículo de modernização e desenvolvimento da escrita árabe, que ainda estava bastante marcada pelo estilo tradicional, arcaísmos e pela rima. O jornal, como suporte, ofereceu a oportunidade

24 "They were rejecting the belief that women's voice is 'awrah, a shame and dishonor." 
para escritores lapidarem um estilo fundamentado na prosa mais simplificada e com uma linguagem mais cotidiana. Resumidamente, desde a retirada da França na Campanha do Egito $^{25}$, em 1801, até a queda do Império Otomano, mais de 100 anos depois, o conteúdo e estilo da escrita árabe testemunharam significativos desenvolvimentos e mudanças (ALMAHROOQI, R. \& DENMAN, C., 2016, p. 10).

Ainda nos fins do século XIX, mulheres não escreviam em colunas de jornais apenas questões que evolviam o universo feminino, mas elas mesmas fundavam redações de jornais. Produziam também antologias biográficas, como a Sccatered pearls on the classes of women 'Pérolas espalhadas nas classes das mulheres', publicada em 1895, por Zaynab Fawwāz. Nessa edição, Fawwāz reúne a vida de mais ou menos 450 mulheres, ocidentais e orientais, famosas por suas realizações no campo social e literário. Além de resgatar a vida dessas mulheres relegadas às margens da história, Fawwāz pretendia, com essas biografias, fazer as escritoras enunciarem discursos políticos que, se declarados de outra forma, seriam, com certeza, censurados (COOKE, 2005, pp. 446-447).

Mulheres e defensores dos direitos da mulher, reconhecendo o potencial revolucionário da imprensa, publicavam artigos e histórias em forma de romance seriado, intencionando educar e persuadir segmentos da população que nunca imaginavam alcançar anteriormente. Os libaneses estavam muito concentrados na tarefa de escrever e na tradução de obras ocidentais, principalmente do francês. $\mathrm{Na}$ imprensa árabe, diversos jornais publicaram histórias originais e traduções, dentre as mais proeminentes: $A l$ Fannān, fundado por Butrus Al-Bustani, em Beirute, nos anos de 1870; Al-Mašriq, criado pelos jesuítas em Beirute, em 1898; e Fatāt Aššsarq, fundado por Labiba Hashim, em 1906. O jornalismo cumpria um papel que persiste até os dias de hoje: era uma plataforma para protestos sociais e expressão literária (AL-'IDA, 2008, p. 17).

Contudo, como enfatiza Cooke (2005), não era só no Egito e no Levante que havia esse movimento em busca de uma sociedade mais homogênea no que tange aos direitos do indivíduo. Na região do Golfo Árabe, onde ainda se encontram as sociedades mais conservadoras do mundo árabe, as cataris não ficaram atrás dos homens em termos de

\footnotetext{
${ }^{25}$ A Campanha do Egito foi uma investida militar realizada durante Revolução Francesa. Nesta empresa, os franceses pretenderam ocupar Egito para se servir do território como uma rota que os levariam à Índia, onde, com o apoio de forças locais, atacariam o domínio britânico daquela região. A campanha militar, que acabou fracassada, foi acompanhada de uma campanha científica, da qual participaram diversos nomes do meio acadêmico francês.
} 
publicação. Assumiram a responsabilidade de se equilibrar entre o desejo de se modernizar e o medo das mudanças radicais. Fatimah Turki (1953), que por vezes escreveu sob o pseudônimo de Umm Akțam, atacou fortemente as desvantagens as quais as mulheres eram submetidas, mas observava também o fato de que não eram os valores ocidentais, considerados libertinos, o que admiravam e tinham como alvo.

É relevante observar que, mesmo diante de todo o cenário europeu, seus modelos sociais e as reivindicações feministas da época, as escritoras árabes pareciam ter claramente estabelecido o modelo social que perseguiam. Contrariamente ao que o Ocidente entende, escritoras árabes apontavam que mulheres árabes não tinham a intenção de reproduzir o projeto social apresentado nos Países do Norte, mas propunham soluções para suas próprias demandas, que surgiam do meio cultural em que estavam inseridas. Suas propostas não assinalavam um abandono de toda a tradição cultural, fosse ela islâmica ou cristã, mas almejavam justiça social e igualdade de direitos em toda a extensão do tecido social. É importante enfatizar que não há uma negação completa dos valores e princípios, mas um questionamento sobre as injustiças imbuídas nos discursos tradicionalmente religiosos impostos na época.

Percebendo as relações entre a política, o literário-cultural e o social, as mulheres, no início da Nahḍah, entenderam que sua libertação dependia da libertação da consciência coletiva dos valores tradicionais que sacralizavam sua inferioridade e as faziam, de acordo com 'Anbara Salam Al-Khalidi (1898-1986) em suas memórias, reféns de 'muros aprisionadores' e ‘cortinas drapejadas'(AL-KHALIDI, 'A., 1997, p. 9 apud AL-'IDA, 2008, p.14).

\section{O romance no Líbano}

Antes de discorrer sobre a emergência do romance entre os escritores libaneses, é necessário apontar que, na virada do século XX, Síria e Líbano não existiam enquanto Estados independentes, mas eram denominados Bilād Al-Šām, ou Grande Síria. Essa noção geográfica tem que ser trazida à mente quando se estuda os romancistas árabes da época. Durante os fins dos anos 1800 e início dos 1900, as fronteiras entre os países árabes, bem como a noção identitária de cada um desses países, apresentavam-se bem diferentes da atualidade. Para além disso, a mobilidade dos escritores, particularmente entre Damasco, Beirute e Cairo, era muito mais fluída, de modo que casamentos entre 
pessoas de diferentes regiões árabes, especialmente escritores, eram mais regra que exceção (SHAABAN, 2009, p. 23)

Como dito anteriormente, foi no despontar da imprensa egípcia e levantina, durante as três últimas décadas do século XIX e início do século XX, que a ficção árabe experimentou sua renascença. Nesse período da história, pontua Najm (1966, pp. 9-10 apud AL-'IDA, 2008, p. 17), os escritores libaneses deixaram de extrair da tradição folclórica uma copiosa variedade da herança da oralidade, que se relacionava com "as histórias dos heróis locais e os feitos dos príncipes e xeiques que governaram a montanha sucessivamente".

O início da década de 1850, na região levantina, foi fortemente marcado pelos conflitos entre facções religiosas. Depois do Massacre de Damasco, de $1860^{26}$, muitas famílias imigraram, trazendo consequências tanto para as regiões que deixavam como para as que se dirigiram. Para a grande maioria dessas famílias, o Egito era o principal destino, mas houve também aqueles que viajaram mais longe, encontrando refúgio nos Estados Unidos, em países da América do Sul e na Inglaterra (ALLEN, R. 1992, p. 182). A despeito do processo migratório, Al-'Ida (2008, p. 17) afirma que numa leitura mais geral dos trabalhos produzidos pelas escritoras pioneiras de ficção árabe, percebe-se que eles se caracterizam pelo foco localizado no contexto libanês.

Por causa das numerosas produções literárias de autoria feminina que, normalmente, são completamente ignoradas pela crítica literária que escreve sobre o período, Shaabani (2009) se dedica a realizar um extenso trabalho sobre as obras publicadas por mulheres desde o período da Nahdah. Sem pretensões de separar os trabalhos publicados por mulheres das obras escritas por homens, com vistas a provar a superioridade de um em detrimento do outro, busca uma maneira de integrá-los num mesmo sistema literário e não reproduzir uma prática de exclusão que, não se sabe se conscientemente ou mero resultado da tradição, tem se perpetuado através dos tempos.

Sendo assim, a autora elenca um grande número de escritoras que, ao longo da história, foram completamente negligenciadas, muito embora seus textos fossem

\footnotetext{
${ }^{26}$ Também conhecido como Conflito do Monte Líbano, de 1860, o Massacre de Damasco foi o ápice do levante que teve início no Monte Líbano, como uma rebelião maronita contra seus senhores drusos. Espalhando-se em pouco tempo por todo país, o conflito alcançou a região de Damasco, onde a população muçulmana ataca a minoria cristã, deixando entre os mortos cônsules americanos e holandeses, dando ao episódio uma dimensão internacional.
} 
equiparados aos de autoria masculina em qualidade e relevância. Dentre as grandes autoras apresentadas no primeiro período da renascença, encontram-se, como outrora citado, Zaynab Fawwāz (1846-1914), com sua obra seminal Husn Awāqib: Ġāda AzZahrah 'Boas consequências: $\dot{G} \bar{a} d a$, a flor' de 1899, sendo seguida de suas contemporâneas Labiba Hashim (1882-1952), com sua obra Qalb Ar-rajul 'Coração do homem’ de 1904, e Afifa Karam (1883-1924) com uma de suas obras mais importantes Baddì a wa Fu'ād 'Baddī a e Fu'ād', de 1906.

Dentre os romances pioneiros supracitados, nos interessa comentar brevemente a respeito da obra de Afifa Karam, pois, embora não seja mencionado em diversos manuais de literatura árabe, de acordo com Shaaban (2009, p. 28), o romance Baddī a wa Fu'ād 'Baddī a e Fu'ād' é o primeiro romance árabe a lidar com as questões da relação entre o Oriente e o Ocidente. Publicado em 1906, estaria trinta e dois anos à frente de Usfür min aš-šarq 'Um pássaro do Oriente', de 1938, de Tawfiq Al-Hakim, aclamado pelo crítico, escritor e tradutor sírio George Tarabishi como o primeiro romance árabe a estabelecer o que se chama de 'a antropologia civilizada', que ele definiu como assunto que se preocupava com as relações entre Oriente e Ocidente.

Segundo Tarabishi, os textos subsequentes ao de Al-Hakim renderam bons frutos na árvore genealógica do romance árabe. Não há um árabe que desconheça Mawsim alHijra 'ilā aš-Šamāl (1968), traduzido ao português, em 2004, como Tempo de Migrar para o Norte $^{27}$. Considerada uma das mais importantes obras árabes do século XX, a novela de Tayeb Salih relata a história de dois sujeitos que passaram parte da vida na Inglaterra, em momentos distintos, regressando ao Sudão, poucos anos depois da

\footnotetext{
${ }^{27}$ Em Tempo de migrar para norte, somos convidados a refletir sobre as relações entre Sudão e Inglaterra a partir da experiência da migração para Londres cosmopolita da década de 1920 e os efeitos do colonialismo em um vilarejo do interior do Sudão, por meio de um narrador anônimo, que aborda os fatos com o olhar crítico de um árabo-africano.

Nascido no mesmo ano em que o Sudão foi declarado uma colônia inglesa, em 1898, o protagonista Mustafa Said nos descreve com certa frigidez como se utilizou de sua genialidade para atingir à cultura ocidental-euro-inglesa, através do discurso intelectual e sedutor, empregue para obtenção de vingança. Quando retorna à sua terra natal, o narrador encontra o protagonista e percebe que Mustafa havia ocupado seu lugar na comunidade. Ávido por saber sobre a misteriosa razão que o levou àquela longínqua região do Sudão, o narrador se aproxima de Mustafa, que confessa a história de sua vida e seus feitos atrozes.

Retratando de forma poética e visceral a relação Colônia versus Metrópole, Tayeb Salih teve seu texto traduzido para várias línguas, bem como estudado, analisado e criticado por muitos vieses, mas principalmente pelo Orientalismo de Edward Said (1978), por figurar entre as obras da chamada literatura pós-colonial (ALVES \& JUBRAN, 2019, no prelo).
} 
independência, quando se conhecem. Contudo, o ponto importante do comentário de Tarabishi reside no fato de que, haja vista a produção e publicação de sua obra ter antecedido a de Tawfiq al-Hakim, essa categoria de romance foi, na verdade, introduzida por 'Afifa Karam, e não pelo referido escritor (SHAABAN, 2009, p. 28).

Baddì a wa Fu'ād 'Baddī a e Fu'ād' é uma narrativa cujos eventos ocorrem tanto no Líbano como nos Estados Unidos. Inicia-se no verão, em um vilarejo libanês, no qual a vida e o status das mulheres na comunidade são descritos pela escritora como uma crítica negativa à sociedade libanesa. A autora lida com as questões de classe social, mas entre os principais tópicos da obra está a questão da identidade nacional, que, segundo Karam, não deveria ser isolada das influências novas ou externas, nem se deixar dissolver ou ser suplantada por tais influências. O romance empenha-se em equilibrar os elementos positivos da cultura árabe com as coisas positivas que os árabes deveriam aprender de outras culturas (SHAABAN, 2009, p. 28).

Nesse romance, os personagens, no desencadear dos eventos, lidam com um importante dilema que o mundo árabe ainda tem que resolver: o equilíbrio entre variação cultural e a tendência moderna de tornar todas as culturas homogêneas. O destino das mulheres árabes ainda é muito governado por esse dilema. Ao tratar da relação entre Oriente e Ocidente e o lugar da mulher em cada um desses polos, Karam demonstra um conhecimento profundo de sua cultura, bem como uma mente aberta para o que pode e deveria ser apreendido do Ocidente (SHAABAN, 2009, p. 28).

O navio no qual as mulheres libanesas deixam o Líbano em direção aos Estados Unidos torna-se um tipo de salão feminista, onde mulheres falam sobre experiências e problemas que enfrentam em família e na sociedade em geral. Elas introduzem novos significados aos costumes há muito estabelecidos e conceitos herdados, como o conceito de honra da mulher, que estava atrelado estritamente ao comportamento sexual. Nas suas discussões, elas ampliam a ideia de modo que acomode diversas atitudes e comportamentos sociais. O que elas acham mais frustrante é que, em quase todos os domínios, mulheres são estereotipadas não apenas como pertencentes ao mesmo sexo, mas tendo uma única identidade, modo de pensar e uma classificação, sem qualquer concessão feita para a singularidade de indivíduos ímpares. Os homens, no entanto, são discutidos como indivíduos dignos de culpa por seus erros e louvados por seus méritos (SHAABAN, 2009, p. 28). 
O modo como o assunto sócio-político da imigração é apresentado reforça a importância de mobilizar uma identidade nacional que tenha a coragem de criticar o que é negativo em determinada cultura, basear-se no que é positivo e se beneficiar das experiências e conhecimento das outras culturas. É relevante enfatizar que essas questões propostas por Karam, no final do século XIX, são reproduzidas também no romance de Salih, que continua a ocupar um lugar de destaque na literatura árabe, sobretudo, por sua temática, enquanto Baddī a wa Fu'ād 'Baddī a e Fu'ād' ainda é desconhecido por muitos.

As reflexões que pairavam sobre as obras de Karam e seus pares foram de significante contribuição para a Nahdah. Apesar disso, a produção literária no Líbano declinou depois da Primeira Guerra Mundial até o início dos anos 1950. No que concerne às mulheres, o declínio foi, de fato, um hiato. Esse enfraquecimento pode ser atribuído aos distúrbios geopolíticos que afetaram o Levante e suas implicações para a identidade religiosa no Líbano.

De acordo com Al-'Ida (2008), em 1920, o Líbano achava-se sob o domínio do mandato francês, depois de as províncias sírias de Tripoli e Sidon serem anexadas ao Monte Líbano. Ao mesmo tempo, Beirute foi removida de Acre, Haifa e Nablus - cidades que outrora faziam parte da província - para se tornar a nova capital do novo Líbano. A identidade e a estrutura do país foram redefinidas juntamente com suas novas fronteiras. Se o nome Líbano se referia à área montanhosa cristã-drusa, agora passaria a compreender também regiões que, anteriormente pertenciam à Síria, com uma população majoritariamente muçulmana.

Com suas novas fronteias e sistema de governo, o país precisava de um caráter. Durante a batalha pela independência e o fim do mandato, parecia que o país tomava uma forma pelo consenso, mas isso deu lugar a um conflito de identidade nacional, restrito ao confessionalismo. $\mathrm{O}$ conflito arrefeceria momentaneamente, vindo à tona toda vez em que um país árabe experienciasse uma revolução (a Revolução Nasserista ${ }^{28}$ e Argelina,

\footnotetext{
${ }^{28}$ Em 1952, os egípcios saíram às ruas em uma ação que pôs fim ao domínio de 70 anos dos britânicos sobre o país. Baseada na ideologia do ex-presidente egípcio Gamal Abdel Nasser, a Revolução Nasserista teve grande influência nos países árabes, nos movimentos pan-Arábicos e autonomistas nas décadas de 1950 e 1960, e continua a ter reflexos significativos no cenário político egípcio ainda hoje.
} 
por exemplo), ou sempre que o Líbano entrasse, ou tentasse entrar, em uma aliança com o Ocidente (o Pacto de Eisenhower ${ }^{29}$, em 1958)

O romance no Líbano, nesse frágil período, sofreu uma crise existencial. Apenas algumas obras escritas por homens surgiram neste momento, sendo a mais proeminente delas Ar-Ragì̆f 'Fatia de pão', de Tawfīq Yūsuf 'Awwād, publicado em 1939. Com exceção de 'Arwa bint al-h̆uțüb 'Arwa, filha dos desgostos', de 1949, escrito por Widad Sakani, não foi encontrada outra obra escrita por uma mulher. Nessa época, Sakani estava morando na Síria, que não mais incluía o Líbano. Com sua perspectiva e atmosfera geral, seu trabalho marca o fim do romance didático. Sendo assim, ele pertence ao período inicial do romance e não reflete a realidade contemporânea da mulher e suas batalhas (AL-'IDA, 2008, p. 22).

Embora nesse momento da história as mulheres não tenham publicado praticamente nada, elas estavam ativas em outras esferas, como no trabalho social e nacional. Depois da Primeira Guerra Mundial, Salma As-Sā’ ig (1964, pp. 77-78 apud AL'IDA, 2008, p. 22) diz que elas trabalharam para criar indústrias nacionais para prevenir a emigração econômica, melhorar os status da classe trabalhadora, aumentar o padrão literário e revisar os sistemas educacionais, com vistas a adequar a dignidade da nação e as necessidades da época.

Para além disso, muitas delas participaram da resistência ao mandato europeu e dos protestos pela independência. Algumas ativistas foram alvejadas por soldados da ocupação; mulheres, ousadamente, confrontaram o sectarismo e tiraram o véu; depois dos massacres na Palestina, elas se posicionaram contra a Declaração de Balfour, que respaldou o estabelecimento de uma nação para a população judaica espalhada pelo mundo em territórios palestinos; participaram ainda de diversas conferências de mulheres e uniram-se a outras mulheres árabes em movimentos internacionais pela paz e pelo desarmamento (AL-'IDA, 2008, p. 23).

\footnotetext{
${ }^{29}$ Em1957, o Congresso dos Estados Unidos aprovou um pacote de sugestões conhecido também como Doutrina Eisenhower. Preocupado com a nova intromissão das potências coloniais na região (o conflito pelo Canal de Suez, entre britânicos e franceses, e o avanço de Israel), Eisenhower, então presidente dos Estados Unidos, acusava o 'comunismo internacional' de agravar e inclusive manipular a situação. Para contrabalançar o suposto avanço do poder soviético na região, Eisenhower sugeriu ao Congresso uma resolução para prestar apoio econômico e militar ao Oriente Médio.
} 
A partir da segunda metade do século XX, a escrita criativa das escritoras árabes estava completamente focada em contos e romances, poucas entre elas se dedicavam à escrita de peças teatrais. O principal tópico abordado por essas obras era a luta pela independência do controle europeu, as guerras civis, opressões políticas e corrupção, além do papel que as mulheres desempenhavam dentro da sociedade patriarcal da época. Essas autoras não se restringiam somente ao ato da escrita, mas eram ativamente envolvidas em movimentos libertários. Neste sentido, “as mulheres árabes não teriam contribuído para literatura sem que reivindicassem a soltura das amarras do lar conservador e sua penetração na esfera pública, até moldá-la de certa maneira" ${ }^{30}$ (ASHOUR et al., 2009, p. 4 apud AL-MAHROOQI, R. \& DENMAN, C., 2016, p. 10).

Al-Mahrooqi \& Denman (2016) acreditam que esse movimento deveu-se em muito à educação de auto nível que essas escritoras recebiam em territórios sob o mandato europeu, fosse no ensino secundário ou no superior, enquanto homens com bastante visibilidade entre os intelectuais, tais como Ahmed Lutfi As-Sayyid, no Egito, Amīn ArRayhānī, no Líbano, e Ma rūf Ar-Rasafi, no Iraque, apoiavam publicamente o direito das mulheres.

A percepção dos críticos de literatura árabe de que os romances escritos por mulheres focam apenas no amor, na família e nos filhos pode ser verdade em parte, se considerarmos o fato de que o privado é também político e reconhecer que os laços mais fortes das mulheres são entre a família e os filhos. Portanto, é natural que a mulher escreva sobre o que ela conheça melhor e mais experiencie. Mas isso não significa que essas mulheres são indiferentes ao cenário político. Suas obras testificam que o gênero não resume sua temática à esfera doméstica. De fato, é notável como as romancistas da década de 1960 são essencialmente políticas, na medida em que seus posicionamentos não se restringiam ao senso comum, talvez um fato que tenha levado à sua marginalização.

Romances como Al-bāb Al-maftūh (A porta aberta, 1963) de Latifa Al-Zayat (egípcia), Laylah Wahīda (Uma noite, 1961), de Colette Khoury (síria), Murāhiqah (Uma adolescente, 1966), de Mājida 'Attār (libanesa), entre outros, revelam uma consciência política retratada nas questões que permeiam suas obras. Mulheres analisam e criticam realidades sócio-políticas. Elas demonstram uma visão que propõe as bases da

\footnotetext{
30 "Arab women would have not contributed to literature without the call to escape the bonds of the enclosed home and enter the public sphere, even shape it to a certain degree."
} 
emancipação do homem e da mulher e para sobrevivência política e prosperidade futura de seus países, mas principalmente do mundo árabe como um todo (SHAABAN, 2009, p. 76).

Al-'Ida (2008) destaca que, muito embora os períodos de guerra sejam marcados por mazelas e horror, entre os escritores libaneses apresentou-se bastante profícuo no que tange à produção literária. Considerados mais poetas que romancistas, eram assim reconhecidos por causa da parcimônia com que as obras eram escritas poucas décadas depois da Primeira Guerra Mundial, antes dos anos 1960, e do florescimento da poesia no mesmo período. No entanto, o final da década de 1960 e início dos anos 1970 testemunharam um salto qualitativo no gênero.

Segundo a autora, escritores exploraram as contradições e complexidades da realidade e suas possíveis ramificações, e trabalharam na criação de um discurso multifacetado, cuja linguagem expressaria múltiplos pontos de vistas e nuances na dicção, consciente das variações do discurso na sociedade que estava se tornando cada vez mais dividida, à beira da guerra civil. Neste esforço, eles eram parte de um desenvolvimento geral do romance, que acontecia em todo o mundo árabe, mas empenhavam-se também no processo de formatação de um estilo próprio.

As escritoras fizeram proeminentes contribuições no que se denomina ressurgimento do romance árabe no Líbano, durante o período de guerra civil. Esse salto qualitativo na produção dos trabalhos pode ser visto nos anos 1970, em escritoras como Hanan Al-Shaykh e suas duas obras Intihār rajul mayyit 'O suicídio de um homem morto', de 1970, e Faras Aš-Šaytān 'Cavalo do Diabo', de 1975. A escrita de Al-Shaykh cristalizou-se no início dos anos 1980, durante o auge da guerra civil, paralelamente com ressurgimento criativo incorporada em escritores libaneses, tal como Elias Khoury, Ḥasan Dawūd, Ahmad Al-Zayn e Rashid Daif.

\section{O contexto da tradução da literatura pós-colonial}

Fruto do contato com a alteridade imposto pela ocupação colonial, a literatura póscolonial surge como um espaço para questionar e confrontar a relação colonizadocolonizador. Tendo por principal objetivo a discussão sobre o encontro do Oriente com o Ocidente, bem como as calamidades consequentes da ocupação do colonizador e os regimes ditatoriais estabelecidos na sequência, este gênero cristalizou-se na literatura 
árabe a partir do anos 1930, a despeito de que, como anteriormente mencionado, já no alvorecer da Nahdah, tenha se manifestado através do texto de 'Afifa Karam Baddī a wa Fu'ād 'Baddī a e Fu'ād', em 1906.

A literatura árabe pós-colonial, enquanto percepção e representação árabe do Ocidente e do encontro de culturas, apresenta-se como um contradiscurso à proposta apontada por Edward Said (2006), em sua obra seminal Orientalismo, o Oriente como invenção do Ocidente, em que se discute os diversos modos de apropriação e criação que autores europeus fizeram da cultura, história e espaços do Oriente, principalmente através da linguagem literária, fossem por obras nativas ou traduções.

De acordo com Said (2006, pp. 275-276), o Orientalismo poderia ser descrito como "um modo de escrita, visão e estudos regularizados (ou orientalizados), dominados por imperativos, perspectivas e vieses ideológicos ostensivamente adequados para o Oriente". De modo que, desde que passou a integrar o imaginário cultural ocidental, a palavra Oriente, segundo o autor, passou a ser associada a conotações e imagens que não se referiam ao Oriente real, mas às ideias que envolviam a palavra.

Foi a partir desse conhecimento construído e difundido no Orientalismo que a dominação europeia sobre o Oriente passou de "textual contemplativa à administrativa, econômica até militar" (SAID, 2006, p. 280). Como resultado de décadas de um tratamento imperialista, o espaço do Oriente passou de estrangeiro a colonial, ou seja, o trabalho exaustivo do discurso do orientalista europeu diante da inexpressividade oriental possibilitou o seu domínio completo.

Considerando o Orientalismo como um consenso de ideias fundamentadas por determinadas asserções consideradas coerentes ao orientalista que compõe obras de autoridade, discursos são legitimados por sua mera reprodução, sem qualquer indagação sobre os fatos. Sustentando uma estrutura conceitual com vistas a justificar a apropriação do Oriente através do colonialismo, o Orientalismo é confrontado por meio da representação do Ocidente nos romances pós-coloniais, que se impõem como um contradiscurso ao discurso ocidental já consolidado, a fim de propor uma outra versão da história.

Se a proposta essencial dos textos orientalistas é reprodução da difamação, subjugação e exotização do outro, as imagens do Ocidente representadas nos romances 
pós-colonial nos remeterá a um processo de idealização e tentativa de se tornar o outro, por meio da assimilação cultural, ao mesmo tempo em que se odeia e rejeita o controle dele sobre si.

Esse processo paradoxal que ocorre no sujeito é observado na narrativa de AlShaykh, discutida no capítulo anterior, Innahā London ya 'azīzī 'É Londres, meu caro', quando seus personagens buscam integração social através da incorporação de hábitos e elementos da cultura britânica, haja vista a insistência de Lamis em aprender o dialeto londrino e usar o metrô, embora se irrite diversas vezes com Nicolas, ao explicar reiteradamente as restrições as quais está submetida por 'ser árabe' e muçulmana. Assim como em Mawsim al-Hijra 'ilā al-Šamāl 'Tempo de migrar para o norte', em que o narrador se apresenta como um indivíduo sujeito à atração à cultura ocidental, enquanto Mustafa demonstra sua repulsa, nos permitindo inferir que ambos seriam as duas faces de uma só pessoa.

"Este duplo atributo da modernidade foi sentido e refletido desde o princípio nas escritas dos intelectuais árabes que responderam à experiência [colonialismo] através de sua escrita. Essas representações do Ocidente evidenciam esse senso de dicotomia, de ambivalência, de atração e repulsa simultâneas pelo seu objeto, e pela modernidade, na medida que ela é per si uma ideia ocidental. ${ }^{31}$ (EL-ENANY, 2006, p.185)

Contudo, se os colonizadores viam o Oriente como Edward Said definiu tão bem em sua obra seminal, como o Ocidente era percebido pelos árabes? Havia uma percepção objetiva e honesta de sua contraparte ocidental? Ou as impressões que tinham sobre o outro eram matizadas por vieses cultural, histórico e ideológico? São essas e outras questões que o texto de Al-Shaykh, assim como de seus pares, busca elucidar enquanto literatura pós-colonial.

De acordo com a proposta orientalista, os árabes agiriam passivamente ante as recorrentes reproduções de sua identidade moldadas pela perspectiva ocidental e, sob regimes ditatoriais, não haveria interessados em se engajar num diálogo real. Portandose de maneira subordinada e inferior, cooperariam, assim, com essas representações ocidentais do Oriente. Entretanto, tendo em conta o surgimento da geração de romancistas

\footnotetext{
31 "This dual attribute of modernity was felt by and reflected from the outset in the writings of Arab intellectuals who responded to the experience in their writings. Their representations of the West evince a sense of dichotomy, of ambivalence, of simultaneous attraction and repulsion towards their object, and towards modernity in so much as it is a Western thing."
} 
da segunda metade do século XX e as propostas temáticas da literatura pós-colonial, esse discurso parece não se sustentar.

Diante dos textos pós-coloniais, sua natureza e contexto de produção, não poderíamos assumi-los como uma réplica no processo dialógico em que, para Said (2006, p. 283), o "Oriente é uma ausência total, enquanto sentimos o orientalista e o que ele diz como presença"?

Poder-se-ia dizer que esse panorama se verifica no plano político-econômico das relações internacionais, porém, no que diz respeito à literatura, observa-se que o desdobramento temático do encontro do Ocidente com o Oriente foi amplamente discutido através das obras. É possível dizer que no processo do diálogo haja um ruído no que tange à recepção desses textos, não por sua deficiência em ser uma resposta autêntica aos discursos enunciados pelo Ocidente, mas talvez pelo fato de estarem sendo manipulados ao serem transpostos aos idiomas de chegada.

À vista disso, Van Leeuwen (2004), ao realizar um estudo sobre as traduções de literatura árabe contemporânea para as línguas europeias de prestígio, verifica que os tradutores europeus seriam inclinados a selecionar títulos que apelariam a um viés mais generalizante dos povos árabes, de modo a homogeneizar a identidade árabe. O que configuraria a prática como parte dos esforços despendidos na consolidação da supremacia europeia, do esquema imperialista de dominação cultural e promoção da representação orientalista dos árabes.

Entretanto, o autor ainda argumenta que é necessária uma abordagem que considere juntamente a linguística textual e os estudos culturais, pois, do contrário, não se pode apresentar uma discussão adequada e útil ao lidar com as complexidades da comunicação intercultural através da tradução. Nesse sentido, pontua a importância do surgimento do romance árabe sob a perspectiva da relação entre gêneros discursivos.

A abordagem das traduções de literatura contemporânea através das relações entre gêneros do discurso, proposta por Van Leeuwen (2004), mostra-se relevante, uma vez que a teoria bakhtiniana considera que a linguagem adquire seu significado em 'diálogo', um ato dualístico do discurso em contextos específicos. Nesse sentido, a produção de sentido se daria por meio do processo dialógico, não se limitando a indivíduos isolados, mas abrangendo grupos sociais, nações e culturas em interação. 
A partir dessa interação, imagens da alteridade são criadas na relação bilateral, em que o significado final seria uma combinação de interpretações dos enunciados do Outro. Os significados e imagens, que definem nossa visão da realidade, são organizados em gêneros governados por determinadas convenções e pelo encadeamento de interações dialógicas. $^{32}$

A teoria dos gêneros do discurso, como proposto por Bakhtin (1997), considera o enunciado uma unidade do discurso que reflete as condições específicas e finalidades de um determinado campo, não só pelo seu conteúdo temático, mas sobretudo por sua estrutura composicional, que prevê recursos gramaticais e lexicais específicos da língua, definindo um campo específico da comunicação. Os diferentes enunciados que comporiam um gênero estariam ligados um ao outro por meio da transmissão entre a história da sociedade e a história da linguagem, refletindo ideologias cristalizadas no tempo e no espaço da enunciação. Esses enunciados seriam manifestados de modo a promover um ato responsivo, em que até o silêncio se configuraria uma réplica.

Diante da concepção de gêneros do discurso de Bakhtin (1997), entendemos que a proposta se adequa ao contexto das relações arabo-europeias, na medida em que o Orientalismo é um campo específico de comunicação que reflete as ideologias formuladas no Ocidente acerca do Oriente e, até o período de inércia que antecede a Nahḍh, como apontado por Said (2006), seria considerado de algum modo um movimento responsivo. No que concerne ao campo da tradução, poder-se-ia inferir que a obra selecionada pelo tradutor, bem como o léxico selecionado na transposição do enunciado para o público do texto de chegada e as manipulações textuais - sejam elas adição ou supressão de excertos - evidenciariam a finalidade do translato e a que agenda ele serviria.

Nesse sentido, quando o tradutor opta por uma palavra e não outra, ou mesmo domestica ou exotiza o texto de partida, cria-se um elemento expressivo em que uma

${ }^{32}$ Note-se que, ao considerarmos a teoria dos gêneros do discurso de Bakhtin na abordagem das traduções de literatura contemporânea, e não apenas sob a perspectiva do Orientalismo de Edward Said, linha teórica mais recorrente na análise dessa matéria, não intencionamos de maneira alguma diminuir, tampouco negligenciar todo o debate construído pelo autor que analisa extensivamente como obras clássicas europeias se prestaram a distorcer a imagem dos povos árabes, seja pela domesticação ou exotização, com vistas a conformar o homem árabe em um sistema de representações tendenciosas. Contudo, entendemos que, ao associar ambas as teorias, seríamos melhor assistidos no processo de elucidação e discussão do complexo contexto de tradução de literatura árabe para os idiomas europeus de prestígio. 
palavra passa a ter seu significado atribuído em relação à outra. Assim, o significado isolado de uma palavra cede lugar para o significado conferido pelo contexto em que se insere. Dentro dessa perspectiva, é possível assumir que as traduções dos textos árabes, ao longo da história, foram concebidas como uma forma discursiva que teria uma agenda a cumprir em diferentes sociedades e contextos de recepção.

Quando Said (2006) nos define o Orientalismo como um campo de estudo composto por um sistema de representações assimilados pelo imaginário Ocidental, poder-se-ia inferir que se desenvolveu no sistema literário europeu, por meio de relatos de viagem, textos científicos, mas sobretudo nas obras nativas e traduções literárias, um gênero orientalista. Isto é, a partir do conteúdo temático específico, o projeto discursivo do autor, cuja matéria principal seria o Oriente, assim como os conceitos cunhados fundamentalmente na concepção europeia do homem oriental, estruturados em uma forma composicional, a textualização desse projeto, ou seja, as seleções lexicais, as estruturas frasais, a variante linguística para a composição desse enunciado permeado pelo estilo individual do autor, todos esses elementos elencados dariam corpo ao que poderíamos denominar gênero orientalista.

A prática de manipulação textual nas traduções de literatura árabe, que remontam às primeiras versões de As mil e uma noites, e o decalque dos elementos desse texto para a realidade do que seria o mundo árabe, assim como os relatórios das incursões missionárias e demais representações de personagens árabes em obras europeias, principalmente durante os séculos XVIII e XIX, impeliram os intelectuais árabes a agir de maneira responsiva ao manifestarem suas demandas internas, assim como questionar o controle europeu, a nível intelectual, político e geográfico, sobre os povos árabes por meio do gênero romance (ALVES, 2019, no prelo).

Com suas demandas manifestas no romance, principalmente na literatura póscolonial, não seria possível assumir, entre os intelectuais árabes, um posicionamento de inércia em relação ao discurso orientalista, mas poder-se-ia dizer que esses textos que são compostos como contradiscurso é enfraquecido seja no processo tradutório, ou na seleção de obras específicas para integrar o conjunto de textos traduzidos no sistema nativo. Ao atermo-nos aos modelos tradutórios que norteiam a transposição desses textos, percebemos que mesmo contestando e confrontando o padrão de domesticação e exotização da alteridade, esse padrão continua recorrente. 
Posto isso, seria coerente dizer que não estamos diante de um fenômeno que representa a ausência árabe, pois, a despeito de obras árabes serem traduzidas imediatamente para as línguas europeias, seu discurso é em muito comprometido e enfraquecido cedendo lugar ao discurso que o tradutor, enquanto leitor privilegiado e investido de autoridade, faz emergir no processo de recriação textual. Essa atitude tradutória cada vez mais recorrente faz do Orientalismo de Said um discurso ainda mais atual nos impulsionando a refletir sobre a importância do papel do tradutor na legitimação de ideologias e discursos no processo de construção da imagem da alteridade.

Essa percepção nos conduz à ideia de que a tradução não se restringe apenas à transposição de um texto de um idioma a outro, mas apresenta-se como uma atitude altamente politizada, que reflete diretamente nas relações históricas, políticas e culturais, mas, sobretudo, em questões sensitivas de identificação cultural e autorrepresentação. Nesse sentido, traduções literárias e intercâmbio cultural estariam diretamente relacionados às relações de poder e condicionados à hierarquia que estratifica as sociedades em hegemônicas e dominada. Assim, seria possível dizer que as relações dialógicas arabo-europeias, no campo da tradução, seriam governadas por forças políticas que classificam o mundo em povos do norte e povos do sul (ALVES, 2019, no prelo). 


\section{CAPÍTULO 3 \\ A tradução de Londres: problemas, escolhas e soluções}

\section{O escopo da tradução}

Tendo em vista o panorama da tradução de literatura árabe no Brasil, a consciência do fazer literário de Hanan Al-Shaykh, a temática do encontro do Oriente com o Ocidente na literatura árabe, a potencialidade da tradução no processo de construção de identidades culturais e as questões sociopolíticas e históricas que envolvem essa prática, apresentaremos a tradução de alguns excertos do romance Innahā London ya azīzì , do árabe para o português brasileiro, bem como comentários acerca da analítica da tradução.

Partindo da tradução do texto em língua árabe, pretendemos discutir decisões tradutórias que evidenciem elementos estrangeiros que constroem a identidade cultural do Outro, buscando sempre estratégias de seleções lexicais que abram possibilidades interpretativas que não retratem o elemento estrangeiro de modo a exotizá-lo, tampouco se valer de apagamentos do mesmo, para que se crie um texto transparente e fluente, tendo sempre em conta a temática da obra, o estilo, intenções do autor e público-alvo.

Por se tratar de um romance que representa de maneira tão enfática a multiplicidade da identidade árabe - expressa pelas nacionalidades libanesa, marroquina e iraquiana contrapondo-se ao "Outro" inglês -, temos como objetivo principal considerar como a tradução forma identidades particulares e as mantém com um relativo grau de coerência e homogeneidade, mas também como cria possibilidades para uma resistência, inovação e mudança cultural em qualquer momento histórico. Pois, não obstante o fato de a tradução ser convocada a remeter-se a diferenças culturais e linguísticas do texto estrangeiro, ela pode, do mesmo modo, fomentar ou suprimir heterogeneidade na cultura doméstica (VENUTI, 1998, p. 68).

Opondo-se radicalmente às traduções que se apropriam do estrangeiro visando domesticá-lo e aculturá-lo, adequando-o de forma a apresentá-lo a um determinado público, Venuti (2013, p. 127) denuncia a fluência e transparência nas estratégias tradutórias anglo-americanas e seu esforço para que a tradição cultural da língua inglesa sustente a tradução domesticando o Outro.

Em Translation changes everything, Venuti (2013, p. 122) discute a tradução do texto que traz tradições culturais da língua inglesa com o intuito de evitar a comunicação de qualquer sentido da língua estrangeira ao leitor anglófono, por exemplo, retendo 
palavras no idioma de partida e adicionando uma frase explicativa como aposto, demonstrando, assim, seu investimento numa tradução transparente, com vistas à supressão de diferenças linguísticas e culturais do texto de partida.

Esse fenômeno de domesticação textual, através de supressão ou adição de trechos ou palavras, é observado na tradução de Innahā London ya azīzì para a língua inglesa Only in London, 2002 -, proposta por Catherine Cobham. Al-Samman (2014, p. 21), ao tratar de questões identitárias na obra de Al-Shaykh, faz um comentário sobre a tradução inglesa, dizendo que, interessantemente, "passagens que se dirigem ao desmembramento do corpo de gênero racial forçado a se conformar ao ambiente inglês dominante foram retiradas do romance na tradução inglesa". 33

Essas decisões no processo tradutório revelam que, na medida em que o tradutor, inconscientemente ou não, cria um novo texto baseado no texto de partida, uma hierarquia de valores linguísticos e ideológico-culturais é erigida na situação, a partir da qual valores dominantes tendem a suprimir diferenças através da assimilação ou marginalização do Outro (VENUTI, 2013, p. 2).

Desse modo, o autor observa que, comumente, enquanto em países hegemônicos a tradução modela imagens de seus Outros subordinados, atestando e indagando valores dominantes, estereótipos étnicos, cânones literários, nos países em desenvolvimento, a tradução modela imagens de seus Outros hegemônicos, com inclinações à absorção de valores estrangeiros (VENUTI, 1995, p. 299).

Com intenções de mobilizar uma tradução mais humanística, Venuti (2013, p. 3) propõe que o processo tradutório deveria transportar diferenças linguísticas e culturais, e não as diminuir para se manter um status quo, independentemente se a língua traduzida ocupa uma posição central ou periférica, maior ou menor, pois “nenhuma língua suporta a estagnação que resulta da restrição ou exclusão do contato com outras línguas. Nenhuma cultura suporta a complacência de permitir que a hierarquia de valores que a estrutura passe sem ser examinada ou criticada" ${ }^{34}$.

Considerando o potencial que a tradução tem de formar identidades culturais e sua contribuição para uma reprodução e mudança social, consideramos também o conceito de ética da tradução, trabalhado por Berman (2007, p. 38), que diz que "o ato ético

\footnotetext{
33 "passages which address the dismemberment of the racial gendered body forced to conform to the dominant English milieu, are missing from English translation of the novel".

34 "No language can afford the stagnation that results from restricting or excluding contacts with other languages. No culture can afford the complacency of allowing the hierarchy of values that structure it to go unexamined and uncriticized."
} 
consiste em reconhecer e receber o Outro enquanto Outro". Deste modo, evitar-se-ia uma postura "Etnocêntrica", ou seja, aquela que "traz tudo à sua própria cultura, às suas normas e valores, e considera o que se encontra fora dela - o Estrangeiro - como negativo ou no máximo bom para ser anexado, adaptado, para aumentar a riqueza desta cultura"; e "Hipertextual", que "remete a qualquer texto gerado por imitação, paródia, pastiche, adaptação, plágio, ou qualquer outra espécie de transformação formal, a partir de outro texto já [grifo do autor] existente".

Com vistas a respeitar o "contrato [grifo do autor] fundamental que une uma tradução ao seu original”, pretende-se, nas palavras de Berman (2007, pp. 38-39), "levar às margens da língua para qual se traduz a obra estrangeira na sua pura estranheza”.

Sendo assim, como suporte para as soluções tradutórias, ponderamos, sempre que possível, a atitude literária que a autora demonstra em relação aos seus textos e de seus pares, pois traria um direcionamento no processo interpretativo da obra. Por exemplo, AlShaykh, em entrevista a Christiane Schlote, para Literary London: Interdisciplinary Studies in the Representation of London (2003), fala sobre o romance Innahä London ya azīzi e sua tradução para o inglês, Only in London, para os quais revisor e tradutor pedem abertura para explicações a respeito de recorrentes referências culturais, tanto inglesa quanto árabe, e recebem o seguinte posicionamento da autora: "Eu não me curvaria apenas pelo bem do leitor. Eu não acho que seja justo. [...] Ambos, de certa forma, queriam mais explicações. Mas, então, eu acho que como um leitor você é inteligente e sabe do que o escritor está falando"35.

\section{Problemas, escolhas e soluções}

Ao analisarmos o texto de Al-Shaykh e sua declarada intenção de expressar sua opinião pessoal sobre Londres no romance, percebemos que o romance não se distingue de seus pares apenas nas esfera semântica que contém, mas também a forma estética, como enunciou suas impressões acerca da cidade e da relação que os imigrantes estabelecem com ela e com sua população diz muito sobre sua atitude literária.

Al-Shaykh, que, como vimos através de sua biografia bem como em suas obras anteriores, se mostra bastante audaciosa e, por vezes, falta com o decoro, imprime as

\footnotetext{
35 "I wouldn't bend only for the sake of the reader. I don't think it's fair. [...] Both of them, in a way, wanted more explanation. But then I think, as a reader you are clever and you know what the writer is talking about."
} 
características de sua personalidade num texto que perturba o leitor, seja nos discursos enunciados pelos personagens, seja na alternância de idiomas, dialetos e sistemas de escrita. Mesmo a maneira como a autora constrói suas frases em árabe padrão exige uma leitura mais atenta, tanto pela dificuldade sintática como pela falta de ambientação no enredo.

Com as traduções de suas obras realizadas na sequência das publicações em árabe, como observa Starkey (2006), a autora tem sido 'acusada' vez ou outra de escrever segundo a perspectiva do leitor inglês, porque estaria mais interessada no mercado editorial europeu do que no árabe. Entretanto, não nos parece ser esse o caso do texto em questão, dado que Al-Shaykh não poupa em nada nenhuma de suas possíveis audiências nas críticas presentes nas falas de suas personagens, nem ingleses nem árabes. O que se perceberá mais adiante, em nossa análise de alguns excertos da versão inglesa do texto Only in London (2002), é que o tradutor, não se sabe se intencionalmente ou não, tornou o texto bem mais palatável ao gosto inglês do que a proposta do texto em árabe.

É sabido que o processo de tradução é criação e também negociação, implicando perdas e ganhos. Uma vez que esse processo se dá a partir da leitura da obra, o tradutor opera como um 'leitor privilegiado', diferente do leitor médio do texto de partida e do texto de chegada, e que essa leitura é única. O tradutor é o indivíduo que tem a capacidade de receber as informações do texto de partida, interpretá-las e apresentá-las na forma do texto de chegada (HATIM \& MASON, 1992, p. 224). Nesse sentido, o tradutor atuaria como um mediador intercultural, não somente por dominar os idiomas envolvidos nesse processo, mas também suas culturas.

Para além do fato de dominar ambos idiomas e culturas, o tradutor é considerado um 'leitor privilegiado' dada a singularidade da leitura que cada indivíduo realiza de um texto, sendo impossível a eliminação completa de traços das perspectivas desse leitor no texto de chegada. No entanto, como comenta Hatim \& Mason (1992), o tradutor, longe de ser um leitor comum, deve ser bastante cuidadoso, para que não imprima em sua leitura suas crenças e valores. Pois, dada a posição que ocupa o tradutor, em certa medida, ele tem o potencial de dirigir leituras a partir de suas interpretações do texto de partida, as quais podem ser completamente enviesadas. Disso decorre a necessidade desse indivíduo buscar sempre realizar uma leitura com vistas a respeitar o contrato que prevê a lealdade ao texto de partida, consequentemente, seu contexto e o discurso manifesto. Assim, as nuances ideológicas, bem como as predisposições culturais compreendidas no texto de 
partida devem ser transmitidas em sua integridade, por meio da visão holística do tradutor. A ele é reputada a responsabilidade de reconstruir todo o Gestalt do texto a partir de fragmentos individuais.

O autor propõe ainda que essa reconstrução ocorre a partir de duas possíveis leituras do texto de partida e que são determinantes na composição do texto na língua de chegada. A primeira leitura consideraria todo o background cultural do leitor, e suas experiências de mundo e como essas informações se relacionam com as que são apresentadas no texto. Deste modo, para o nosso trabalho, o conhecimento do sistema literário do texto de partida nos permite obter uma compreensão maior do significado de uma obra em particular. Ao debruçarmo-nos sobre a compreensão da história da tradução de textos árabes paras as línguas europeias, a posição de Al-Shaykh na literatura árabe, o processo de colonização desses povos, de exploração e domínio cultural, assim como, a imigração de povos árabes à capital britânica, temos uma percepção mais aprofundada do texto Innahā London ya 'azīzì, que ganha um novo significado em relação não só aos fatos mencionados, como também em relação às outras obras que figuram no mesmo sistema literário que ela.

A segunda leitura mantém-se no nível do próprio texto. Trata-se de como o leitor processa o léxico e a sintaxe, decodificando essas informações de modo a construir significado conforme avança na leitura. Foi no processo dessa segunda leitura - que, inconscientemente, se dá ao mesmo tempo que a primeira - que tivemos um certo desconforto e estranhamento diante do romance de Al-Shaykh. Pois, muito embora algumas obras pós-coloniais façam uso de estrangeirismos em seu texto como forma de marcar a presença do colonizador na cultura nativa, o romance em análise, como veremos adiante, é construído de modo a incomodar o leitor com as intervenções de palavras estrangeiras e sistemas de escrita que se misturam (cf. p. 59 Jaccuzill). Além da interpolação de palavras e sentenças estrangeiras, há ainda a alternância dos dialetos, que variam de acordo com a origem do personagem e de seu interlocutor. Toda essa heterogeneidade leva a um tecido final constituído de diversos retalhos, fragmentos culturais e identitários, que compõem um discurso alinhavado com o fio da imigração.

À vista disso, como propõe Hatim \& Mason (1992), podemos assumir que o contexto de produção da obra exerce uma influência determinante na estrutura e no estilo do discurso, enquanto a interação semiótica define o texto como um signo entre outros 
signos, que adquire significado no contexto cultural. A compreensão do contexto de produção do texto oferece uma chave de leitura que nos leva a perceber a interação dos signos na própria obra. Assim, Innahā London ya 'azīzì pode ser reconhecida como uma mostra de um determinado gênero e como a expressão do discurso crítico, um meio entre a consideração razoável e a polêmica provocativa.

No entanto, muitas dessas nuances do texto passam despercebidas ao leitor do texto em língua portuguesa, em muito justificado pela ausência de um projeto de literatura árabe no Brasil, e falta de parâmetros de referência para que haja esse tipo de apreciação da obra. Ademais, é de grande importância refletir sobre as leituras europeias dos textos árabes quando traduzimos essa literatura ao português brasileiro, pois, apesar de a língua portuguesa não figurar uma posição de prestígio dentre as línguas europeias ${ }^{36}$, as leituras realizadas sobre a cultura e literatura árabe predominantes no Brasil são, majoritariamente, enviesadas de acordo com o discurso euro-americano. Assim como as obras traduzidas do árabe ao português são, muito frequentemente, os títulos que fizeram sucesso em países como Inglaterra, França e Estados Unidos. Desta atitude decorre o fato de que o conjunto de obras árabes existente no sistema literário brasileiro seria definido segundo o gosto do público euro-americano (ALVES \& JUBRAN, 2019, no prelo.).

Deste modo, se tomarmos a experiência que o leitor médio brasileiro tem com a literatura e a cultura árabe, considerando o nosso texto de partida, na interferência do tradutor no processo de mediação, caberia muitas explicações e domesticação textual para que se tornasse mais compreensível, haja vista as recorrentes referências a elementos da cultura árabe e da cidade e cultura britânica. Esse problema talvez não ocorresse, ou se daria em um nível muito menor, se se tratasse de um texto da cultura euro-americana majoritária, que é mais difundida, seja porque ela se impõe como uma cultura de supremacia, seja porque, de alguma forma, partilhamos dessa cultura também pela herança colonial.

Portanto, no trabalho de criação do texto traduzido, priorizamos ao máximo a manutenção das heterogeneidades, porque seriam partes determinantes do escopo do texto de partida, muito embora tivéssemos em conta que parte importante dessa

\footnotetext{
${ }^{36}$ Não obstante a complexidade de classificação das línguas hierarquicamente, quando nos referimos a línguas de prestígio, consideramos não só a distribuição geográfica do idioma ou o número de falantes nativos, mas, sobretudo, seu uso em organizações internacionais e relações diplomáticas, assim como a relevância econômica e política de seus falantes nativos no cenário global.
} 
diversidade seria perdida com a homogeneização dos sistemas de escritas. No entanto, essa perda poderia ser compensada, por exemplo, com a manutenção de expressões em língua árabe, o que ao público de língua portuguesa provocaria um estranhamento e uma heterogeneidade no nível linguístico.

Dessa negociação que envolve perdas e ganhos, entendemos que a tradução é criação e, também, crítica, pois no processo de desconstrução do texto literário, através da leitura e interpretação, damos ao texto de partida um novo corpo e novos significados que o unem ao texto de chegada e oferece novos sentidos à comunidade receptora.

Esse processo de recriação, segundo Campos (2004), nasce da impossibilidade da translação de um texto de um idioma a outro sem que se perca sentido e forma do texto de partida, já que quando tratamos de linguagem literária, lidamos com a sentença absoluta, aquela que "não tem outro conteúdo senão sua estrutura", a "que não é outra coisa senão o seu próprio instrumento" e que não pode ser traduzido (p. 33). Do impasse em se traduzir essa estrutura estética, nasce no processo de (re)criação de um novo texto.

Campos segue dizendo que "a informação estética não pode ser codificada senão pela forma em que foi transmitida pelo artista, por que nela se encerram a imprevisibilidade, a surpresa". Com isso, ele se refere ao que Bense (1958 apud CAMPOS, 2004) definiu como impossibilidade de uma 'codificação estética', ou seja, a informação estética é igual à sua codificação original. Nesse sentido, qualquer intervenção no texto de partida provocaria um desvio da informação estética que foi proposta pelo autor, de modo que a nova configuração não seria mais a inicial. A informação estética é, assim, inseparável de sua realização, "sua essência e sua função estão vinculadas a seu instrumento, a sua realização singular” (p.34).

Não obstante nosso reconhecimento da tradução como (re)criação, entendemos que, para o nosso corpus, o discurso e função do texto não poderiam ser sacrificados em prol de uma criação em que fosse priorizada sua função estética, considerando o escopo original. A partir dessa perspectiva, tentamos criar um novo texto que causasse uma certa perturbação no leitor, assim como o texto de partida, mantendo todas as referências sem que se fosse oferecida qualquer explicação, seja no que diz respeito à cultura árabe ou à britânica. Sendo assim, para a finalidade deste trabalho, selecionamos para a discussão excertos da obra que a distingue enquanto uma obra provocativa e que nos parece ter por finalidade incomodar o leitor. 


\section{Dialetos $^{37}$}

Como dito anteriormente, Al-Shaykh preocupou-se em representar a diversidade árabe sob diversas formas, e uma bastante explorada ao longo do romance foi as variações dialetais e o fenômeno do code-switching, ou alternância linguística, muito recorrente na situação de imigração. Como veremos mais adiante, a alternância tanto de um dialeto árabe a outro, ou do árabe ao inglês, assim como também a distinção entre o dialeto inglês londrino e o falado por imigrantes árabes são aspectos explorados pela autora, remetendo ao status social que cada uma dessas variações tem na comunidade árabe e na comunidade londrina.

A escritora, nos trechos de diálogos, realizou as variações dialetais de acordo com a origem dos sujeitos envolvidos, deste modo, temos sobreposições linguísticas representadas em diálogos no dialeto egípcio, libanês, iraquiano e um registro do árabe padrão com intervenções dialetais. A ocorrência dos dialetos também nos parece ser uma representação de certo status de prestígio que há entre um dialeto e outro, comum nos países árabes ${ }^{38}$. Esse fenômeno é normalmente explicado a partir da maior produção e difusão das artes cinematográfica e literária de um país em relação ao outro. Por exemplo, os dialetos egípcio e levantino são mais conhecidos pela comunidade árabe como um todo, devido ao cinema vanguardista egípcio e às novelas e músicas sírio-libanesas, assim como o marroquino é reconhecido por arabófonos por ser mais difícil de ser compreendido. É interessante mencionar que alguns árabes de países do Levante ou

\footnotetext{
${ }^{37}$ Uma vez reconhecida a dificuldade de se estabelecer um conjunto de categorias que possibilite a classificação de variantes de uma língua como um todo, para este trabalho adotaremos as definições de dialetos e registros proposta por Hatim \& Mason (1992) que diz que nos chamados dialetos, é possível detectar variação em todos os níveis da língua. Assim, os dialetos podem variar de acordo com o falante nos seguintes aspectos: geográfico, temporal, social, (não) padrão e idioleto. os chamados registros, é perceptível sua variação, principalmente pela forma da linguagem, diferindo um do outro nos aspectos gramaticais e lexicais, por exemplo. $\mathrm{O}$ registro seria o termo utilizado para o tipo de variante utilizada, considerando a relação existente entre dada situação e a linguagem utilizada para enunciação, ou seja, a depender do campo do discurso, o modo do discurso e o tom do discurso. Todos esses elementos estariam mais relacionados à convenção que diz que dado enunciado linguístico é apropriado para determinado uso. Deste modo, a definição de dialeto seria orientada para o usuário, ou seja, o sujeito da fala, enquanto o registro para uso e situação de fala.

${ }^{38}$ Esse reconhecimento do prestígio dos dialetos egípcio e levantino não se restringe aos países árabes, haja vista a existência de diversos materiais de ensino de língua produzidos no Ocidente que ensinam, paralelamente à variante padrão da língua árabe, esses dialetos. À guisa de exemplificação, temos o Al-Kitāb fĩ Ta'allum Al-'Arabiya, de Kristen Brustad, Mahmoud AlBatal e Abbas Al-Tonsi, publicado pela Georgetown University Press, bastante utilizado nas universidades de países ocidentais e em escolas de idiomas nos países árabes
} 
mesmo do Golfo costumam dizer, em tom jocoso, que no Marrocos não se fala árabe, tamanha a diferença entre os dialetos.

Esse fenômeno é percebido por meio da personagem Amira, a prostitua marroquina, que está sempre alternando o dialeto a depender do seu interlocutor e nunca fala em marroquino, revelando, assim, um domínio dos dialetos levantino e do egípcio, do árabe padrão, assim como um vocabulário expressivo dos dialetos iraquiano e do Golfo. Samir, o libanês que nunca havia deixado o Líbano antes, faz uso apenas de seu dialeto materno e, mesmo quando está falando com um estrangeiro, no que a autora faz soar como um diálogo em língua inglesa, ele faz diversas alternâncias com palavras em árabe.

Quando passamos ao contexto de fala de Lamis, percebemos que a personagem, na maioria de suas interlocuções com personagens árabes, faz uso de um registro do árabe padrão que contém a interferência de palavras em dialeto, seja quando fala com seus pais iraquianos ou com o filho, nascido na Inglaterra. Khalid, que vive num contexto bicultural, está sempre fazendo uso da língua inglesa, mesmo quando fala com a mãe, e em determinados trechos do texto, o personagem demonstra não ter domínio da língua árabe, por exemplo, quando pede a sua mãe que traduza um texto escrito pelo avô (cf. p. $314)$.

Por ter vivido nesse contexto bicultural durante 13 anos, Lamis, ao se divorciar, procura uma professora de língua inglesa para aprender o dialeto londrino, pois devido à vivência restrita à comunidade árabe imigrante, a personagem sente que embora se comunique muito bem, faz uso de um registro inglês que a identifica como imigrante. Com intenções de se tornar uma 'autêntica inglesa', por portar passaporte britânico e ter vivido tanto tempo no país, Lamis impõe a si mesma o dever de aprender a falar como os londrinos, como forma de se integrar à sociedade londrina (cf. p. 31). Assim, a personagem, quando fala com Nicolas, tenta ao máximo fazer uso das expressões inglesas, com vistas a soar o mais natural possível, muito embora quando se sente insegura, sua estrangeiridade torna-se logo evidente, através de sua pronúncia árabe da língua inglesa (cf. pp. 145, 229, 231).

Os personagens secundários de origem árabe sempre usam o dialeto egípcio ou levantino, exceto um personagem específico originário do Golfo, que usa uma variante do árabe padrão. Para além dessas ocorrências, resta apenas comentar que os diálogos que 
supostamente se dariam em língua inglesa são registrados no árabe padrão, com a introdução de vocabulários no inglês, ora grafados no sistema de escrita árabe, ora no sistema latino (cf. pp. 145, 191, 223, 313-314).

Diante de um texto que apresenta um contexto de plurilinguisimo, Hatim \& Mason (1992) atribuem toda a responsabilidade ao tradutor no que concerne aos aspectos ideológicos e políticos implicados na variação dialetal geográfica. Por geralmente estar diretamente ligada ao status que determinada região e pronúncia têm para uma sociedade, por exemplo, é uma das características mais evidentes no que tange à variação geográfica, e é com frequência fonte de problemas. O tradutor deve estar sempre atento às implicações sociológicas que suas decisões trarão para a obra. Se traduzir um dialeto do texto de partida pela língua padrão do texto de chegada tem a desvantagem de se perder o efeito pretendido, por outro lado, ao traduzir dialeto por dialeto corre-se o risco de se criar efeitos que podem ou não ser entendidos ou mal interpretados.

Diante do impasse de tantas sobreposições linguísticas, na impossibilidade de representá-las todas, decidimos por fazer uso de uma variante coloquial do português, com vistas a marcar a diferença de registros, e para criar um efeito de heterogeneidade textual, optamos pela manutenção de algumas expressões em árabe e, em outros momentos, ao invés de fazer usos de equivalentes cristalizados no português brasileiro, nos mantivemos fiéis à letra, fazendo uma tradução mais literal. Tivemos também a preocupação de, sempre que possível, fazer traduções que trouxessem um pouco da أفندم cultura popular de cada dialeto, como, por exemplo, na preservação do vocábulo (Afandem - 'senhora') de origem turca, bastante recorrente no dialeto egípcio, e trazido por Al-Shaykh na fala das personagens, no segmento abaixo:

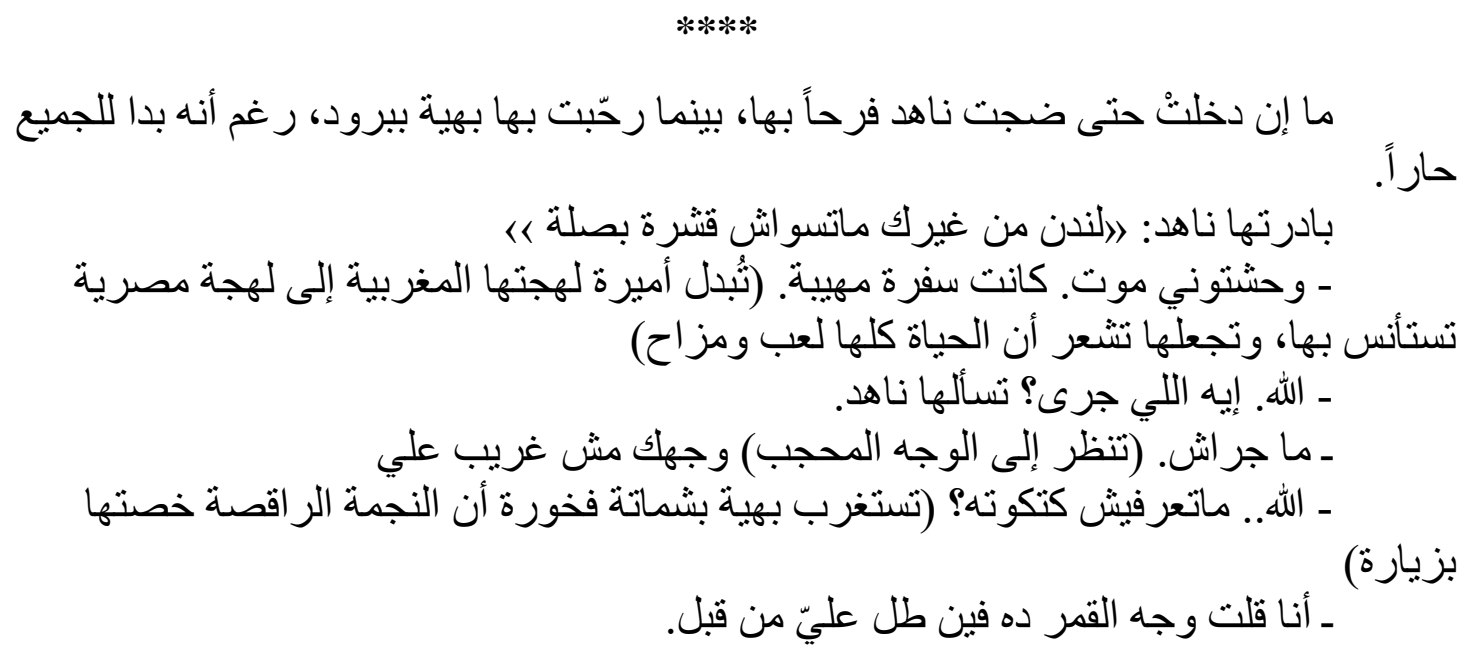




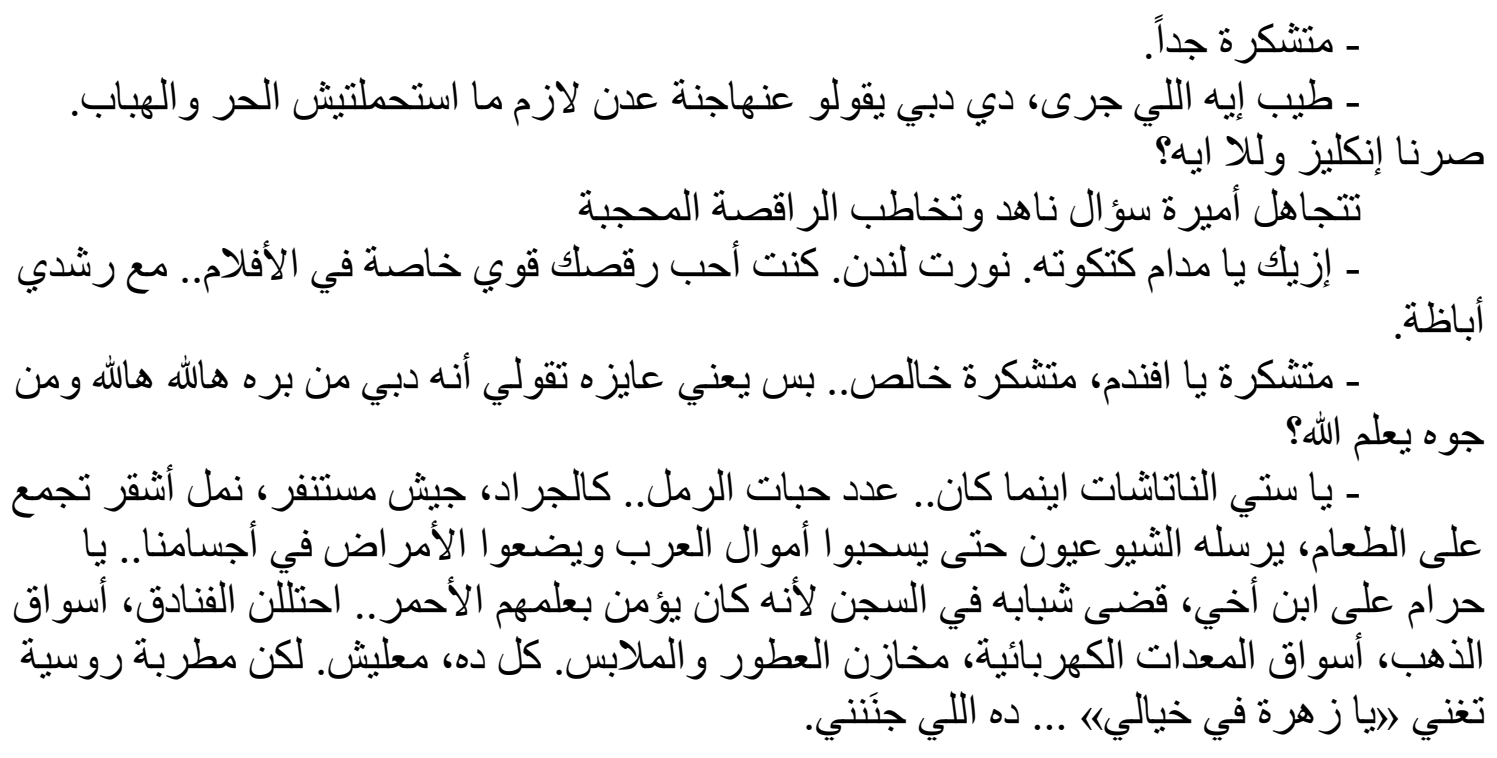

(pp. 53-55)

Assim que entrou, Nahid gritou alegremente, enquanto Bahia a cumprimentava friamente, apesar de parecer cordial para os demais. Nahid apressou-se: "Londres sem você não vale uma casca de cebola".

"Morri de saudades. A viagem foi um desastre." (Amira mudou o seu dialeto marroquino para o dialeto egípcio, com o qual já estava acostumada e a fazia sentir que a vida era folguedo e chiste.)

“Allah, o que aconteceu?” Perguntou-lhe Nahid.

"Não aconteceu". (Olhou para o rosto envolto no hijab). "Teu rosto não me é estranho."

"Poxa... não reconhece a Katkuta?" (estranhou-se Bahia cheia de orgulho pela visita da famosa dançarina).

"Eu pensei comigo mesma, ela tem cara de estrela, onde eu vi antes?"

"Muito agradecida."

“Tá bom, o que aconteceu? Dizem que Dubai é o Jardim do Éden. Você não deve ter aguentado o calor e a poeira. Nós somos ingleses ou o quê?"

Amira ignorando a pergunta de Nahid dirigiu-se a dançarina com seu hijab:

"Como vai Madam Katkuta? Você ilumina Londres. Eu amava de paixão a sua dança, especialmente nos filmes... com Rushdi Abaza."

"Agradecida, afandem, muito agradecida... mas então você quer dizer que Dubai de fora wala wala e de dentro sabe Allah?"

"Querida tem Natashas para todo lado... numerosas como grão de areia, como gafanhotos, um exército de prontidão, formigas loiras ao redor da comida, são enviadas pelos comunistas para pegar a riqueza dos árabes e passar doenças para os nossos corpos.... tadinho do meu sobrinho, passou a juventude na cadeia porque acreditava na bandeira vermelha...elas invadiram os hotéis, os mercados de ouro, as lojas de materiais elétricos, as lojas de perfumes e roupas. Isso tudo, vá lá. Mas uma russa cantando " $Y a$ Zahrahtan Fi Khayali”!... isso me enlouqueceu...." 
Tendo em vista nosso propósito de introduzir ao leitor do $\mathrm{TC}^{39}$ uma nova dimensão cultural, transpomos a expressão “لندان من غيرك ماتسواش قشرة بصلة (London min gêrik matiswāš 'i šrit baṣala), Londres sem você não vale uma casca de cebola, em lugar de 'Londres sem você não vale nada', ou 'não tem graça', 'não presta', que é bastante recorrente no português brasileiro, considerando que, dentro do contexto em que a expressão é enunciada, é possível apreender o significado proposto originalmente, sem que se crie um estranhamento que provoque a incompreensão. Isso se nota neste mesmo trecho, mas algumas falas posteriores, com a frequente repetição da interjeição "الله"

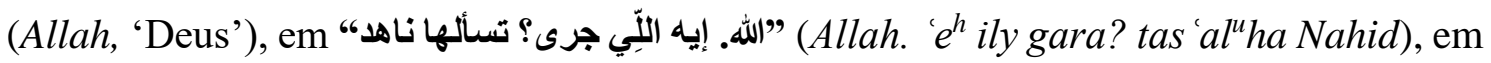
que optamos pela manutenção de Allah, 'Meu Deus', embora tivéssemos também a possibilidade de utilizar a variante 'Por Deus', expressão popular de bastante frequência no $\mathrm{PB}$, porque nessa ocorrência só a palavra Allah dá conta de transmitir o significado guardado nas expressões em ambas as línguas. No entanto, na segunda ocorrência da mesma palavra nesse segmento "الله. ما تعرفيش كاتكوته؟" (Allah. Mā ta’arafǐš Kātkwuta ${ }^{h}$ ), decidimos por usar a expressão 'Poxa', pois entendemos que ao repetir a mesma forma pela segunda vez pudesse levar o leitor à mesma interpretação das formas, o que não ocorre no árabe.

Pensando na musicalidade do dialeto árabe egípcio, expresso na fala de uma das personagens do diálogo reproduzido acima, trouxemos "من برّه هالله هالله ومن جوّه يعلم اللهة (Min barr $^{h}$ ha- 'Allah ha-'Allah w- min juwwa' ya 'alam 'Allah) como 'de fora wala wala e de dentro sabe Allah' em que Ha-Allah Ha-Allah traz uma musicalidade com a repetição da palavra Allah (Deus), mas que não poderia ser reproduzida na língua de chegada, dada as diferenças sonoras entre os equivalentes. Diante dessa questão, poderíamos simplesmente utilizar o equivalente em PB, que mais se aproxima do valor semântico do TP cristalizado na seguinte forma: 'Por fora bela viola, por dentro pão bolorento'. Porém, entendemos que neste período a musicalidade teria maior peso no contexto do que a precisão do conteúdo. Por isso, buscamos emular essa malemolência presente no dialeto egípcio, sem que se perdesse completamente a ideia contida no original, em detrimento de uma maior precisão semântica.

Ainda no que diz respeito à música, optamos pela manutenção da letra em árabe da canção referida pela personagem Amira, na última linha do diálogo transcrito, ainda com intenções de acentuar essa heterogeneidade textual. Diferentemente, o tradutor para

\footnotetext{
${ }^{39}$ Daqui em diante lê-se TP, como texto de partida, e TC, texto de chegada.
} 
o espanhol faz a tradução desse trecho como de todos os outros versos de canções presentes no texto, seja ele em língua árabe ou língua inglesa (cf. pp. 51, 19).

Com vistas a marcar a falta de fluência no inglês de alguns personagens no processo de interação, a escritora faz o registro em árabe padrão com intervenções dialetais, assim como a tradução de algumas palavras ao inglês na sequência. Entendemos que essa forma de registro, bastante recorrente, sirva para marcar que a interlocução está ocorrendo majoritariamente em língua inglesa, apesar dos ruídos causados por expressões em árabe. Como se vê abaixo, essa diferença existe entre o padrão e o dialeto libanês da fala de Samir, manifesto em: "معلهش انس الموضوع، المهم الصحة" (Ma aleeš 'insa al$\left.m a w d \bar{u}^{c} a\right)$ e ماذا (mādā), 'que, qual', em lugar de sua variante dialetal شو $(\check{s} \bar{u})$. Essas manifestações, que sofreriam um apagamento ao serem transpostas ao PB, foram preservadas, por meio do uso do mesmo recurso que a escritora utilizou para a introdução da tradução das palavras 'same same', ou seja, mantivemos معلش (Ma 'aleeš), e também fizemos uso de infinitivos em lugar de verbos conjugados. Assim como nos outros excertos em que há ocorrência de letras de música, a canção infantil em árabe foi também reproduzida.

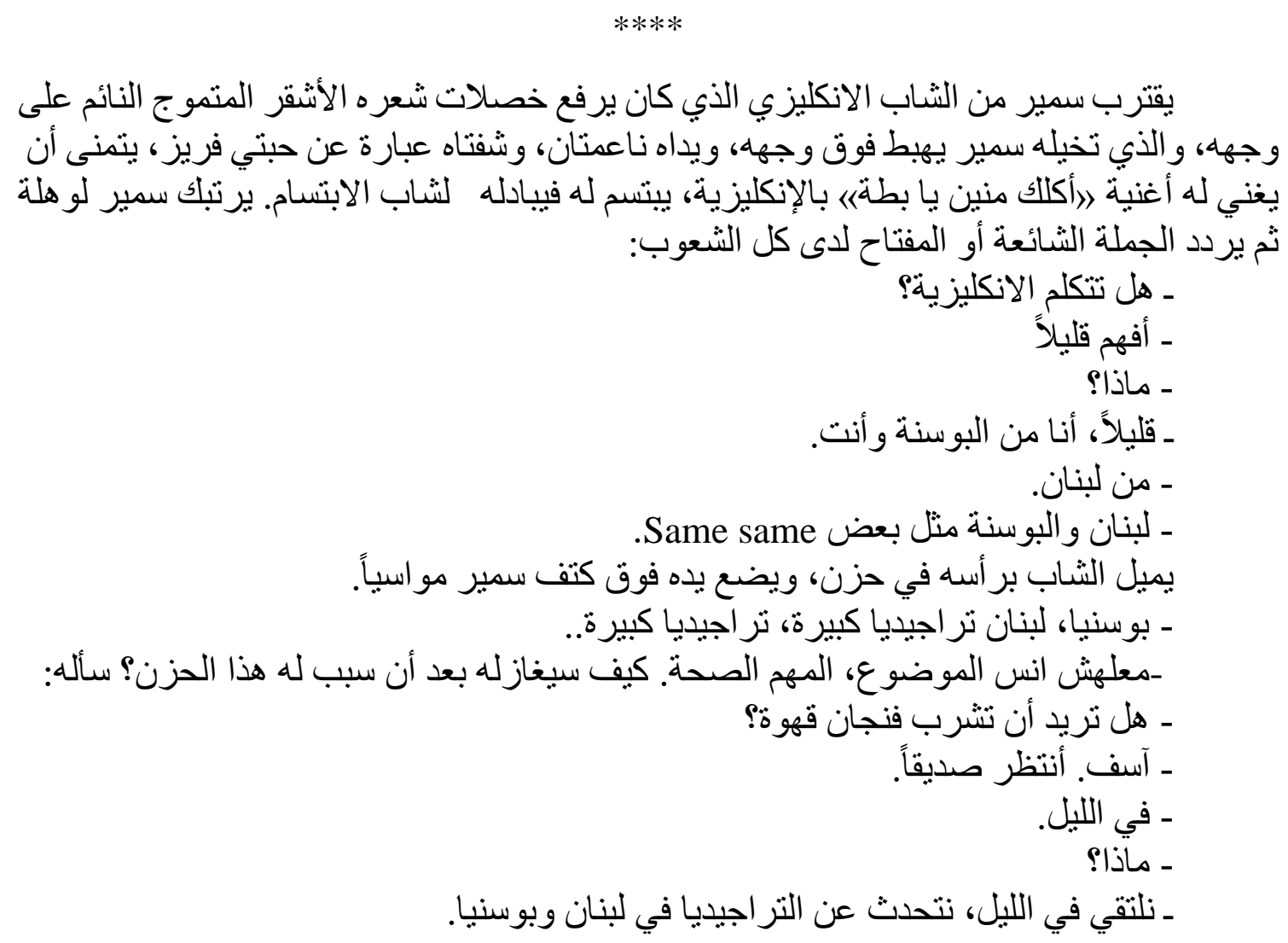




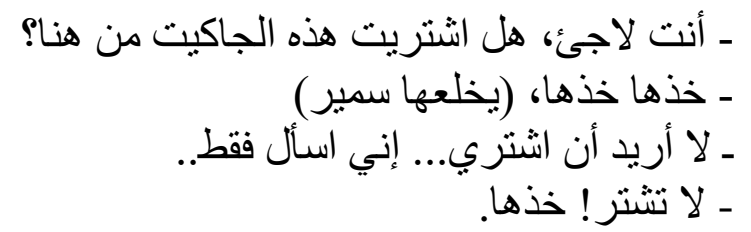

(pp. 129-131)

Samir aproximou-se de um rapaz inglês que tirava as mechas de seu cabelo louro e ondulado que caíam sobre seu rosto. Samir imaginou-as caindo sobre seu rosto, suas mãos macias e seus lábios como dois morangos. Queria que ele lhe cantasse " Aklik minīn ya bata" em língua inglesa. Ele lhe sorriu e o jovem sorriu de volta. Samir ficou intrigado a ponto de corar-se, e repetiu a recorrente frase ou chave entre todos os povos:

"Você falar inglês?"

"Entendo um pouco."

"Que?"

"Um pouco, eu sou de Bósnia e você?"

"Do Líbano."

"Líbano e Bósnia, mesma coisa. Same Same."

O jovem inclinou a cabeça com tristeza, colocando a mão no ombro de Samir de forma consolatória.

"Bósnia, Líbano... são uma grande tragédia, uma grande tragédia. Ma 'aleech, não faz mal, deixa isso pra lá, o importante é a saúde." Como ele flertaria com o moço depois de lhe causar esta tristeza? Perguntou-lhe:

"Você quer tomar uma xícara de café?"

"Desculpe. Estou esperando um amigo."

"De noite."

"Que?"

"Nos encontramos de noite, aí conversamos sobre as tragédias no Líbano e na Bósnia."

"Você é um refugiado, comprou essa jaqueta aqui?"

"Pega, pega." Disse Samir tirando-a.

"Não quero comprar... Só perguntei."

"Não é pra comprar! Pega."

$* * * *$

O excerto que segue representa um uso de um registro peculiar de dois personagens específicos. O primeiro é a do filho de Lamis, que está sempre a falar com a mãe num registro do árabe padrão com interpolações de palavras no inglês, aqui grafados no sistema de escrita árabe. O fato de o garoto pedir à mãe que traduza o que seu avô lhe escrevera denota sua falta de fluência no idioma nativo de seus pais, o que representa muito da realidade dos filhos que nascem no país da imigração e se distanciam da cultura de origem. Além do registro de Khalid, temos um outro registro, dentre os outros vários utilizados por Amira. Na interlocução com Lamis, a marroquina demonstra um certo conhecimento do dialeto iraquiano, mas mesmo assim faz uso de um registro que se utiliza majoritariamente do variante padrão com algumas ocorrências dialetais. 


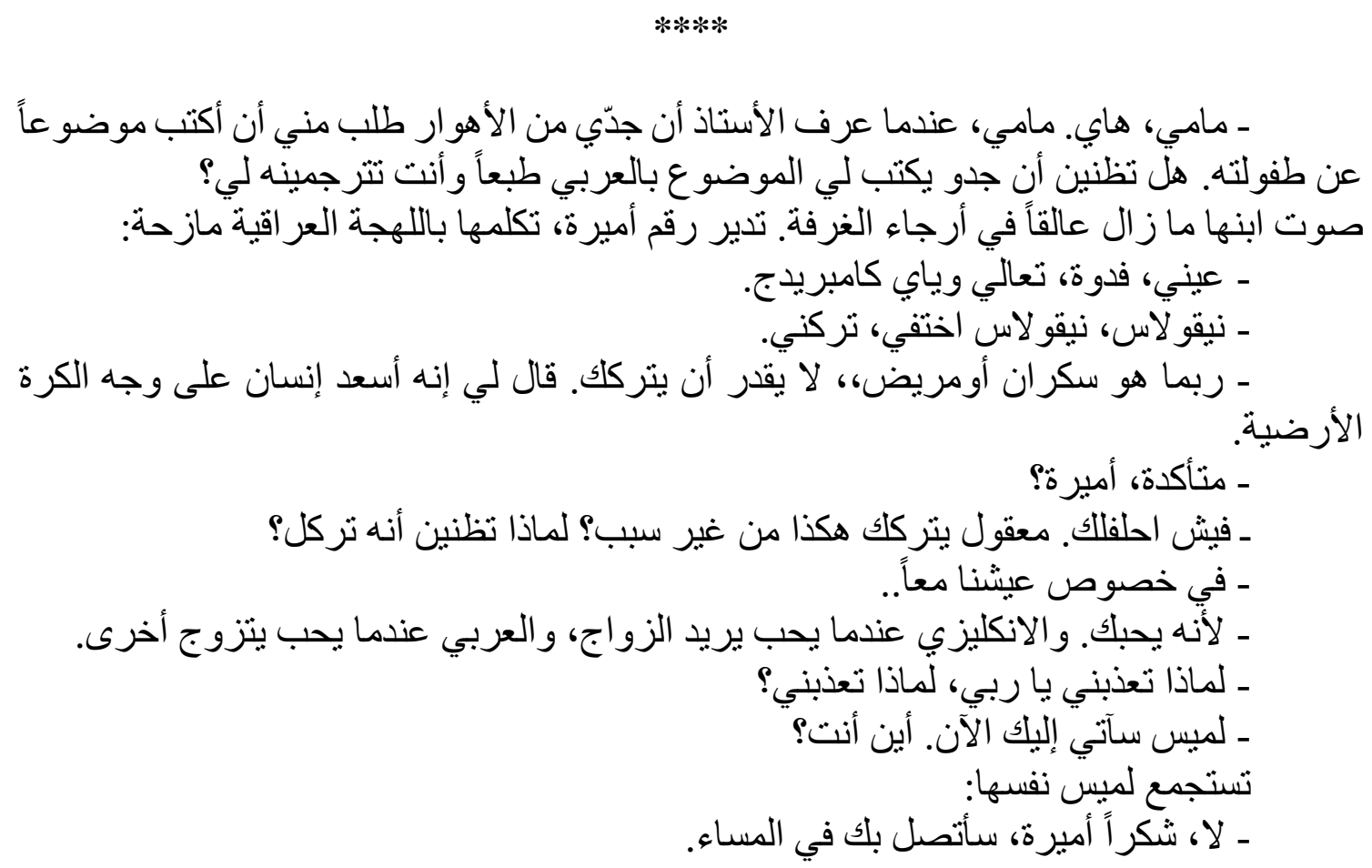

"Mamy, hi, mamy, o professor ficou sabendo que o meu avô é da região dos pântanos mesopotâmicos e me pediu que escrevesse sobre a infância dele. Você acha que o vô escreveria para mim em árabe, claro, e você traduziria?"

A voz de seu filho pairava por todo o quarto. Discou o número de Amira, que lhe falou em dialeto iraquiano brincando:

"Ayni, fadwa, venha comigo a Cambridge."

"Nicolas, Nicolas desapareceu, me deixou."

"Talvez ele esteja bêbado ou doente, ele não pode te deixar. Ele me disse que é a pessoa mais feliz da face da terra."

"Certeza, Amira?"

"Pelo que te juro? Faz sentido te deixar assim sem motivo? - Por que você acha que ele te deixou?"

"Principalmente por vivermos juntos..."

"Porque ele te ama. E o inglês quando ele ama ele quer casar. $\mathrm{O}$ árabe quando ama casa-se com outra."

"Senhor, por que me torturas? Por que me torturas?"

"Lamis, vou te encontrar agora. Onde você está?"

Lamis se recompôs:

"Não, Amira, obrigada. Eu te ligo de tarde."

$* * * *$

É interessante observar que Amira, numa mesma fala, faz uso do dialeto e da variante padrão. Ao alternar formas como "فيش احلفلك" (Fiš 'ahlifilik - Pelo que te juro) do dialeto e "لماذا تظنين أنه تركلك" (Limāẹa tađunīn 'anahu tarakaki? - Por que você acha que ele te deixou?), do árabe padrão, a personagem nos parece usar um registro 
intermediário, que transita entre o discurso formal e o informal. É possível atribuir esse fenômeno ao fato de que Lamis, embora árabe, pertença a uma classe social que difere do meio de Amira, já que quando interage com Samir ou suas amigas, o faz em dialeto egípcio ou levantino.

\section{Anglicismos}

Como forma de representação da interação entre a comunidade árabe e o meio britânico, a autora trabalha a inserção de anglicismos ao longo de todo texto. Essas palavras, ou até mesmo frases, ora aparecem grafados no sistema de escrita árabe, como vimos no item anterior na fala de $\mathrm{Khalid}^{40}$, ora em alfabeto latino, como exposto nos excertos que se seguirão. É importante notar que nem sempre as palavras em língua inglesa obedecem a um padrão de transliteração, ou seja, a mesma palavra pode ser grafada de diferentes maneiras, inclusive, num mesmo trecho de texto. No texto, AlShaykh refere-se à famosa avenida londrina Edgward Road, grafando-a de maneiras diferentes, inclusive no mesmo trecho. As três formas mais recorrentes ao longo do romance são: ادجور رود (Idjūr Rēd), que aparecem geralmente em trechos escritos em árabe padrão, e as variações شارع دجور ( 'Ajūr Rīd - (a Edgward Road) -, as quais ocorrem apenas nos diálogos entre as personagens.

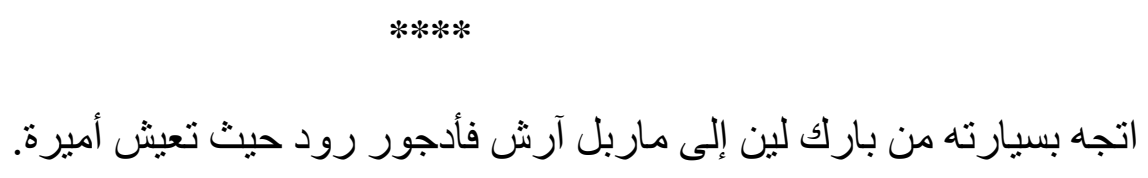

(p. 70)

Nicholas dirigiu-se de carro de Park Lane para o Mable Arch e então para a Edgward Road, onde Amira morava.

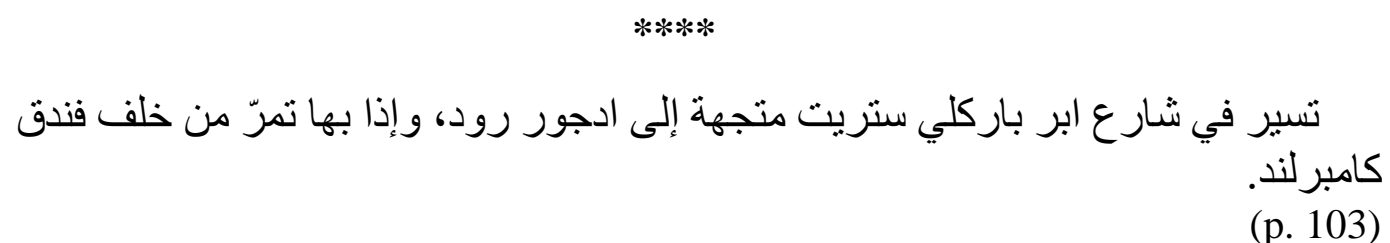

\footnotetext{
${ }^{40}$ Para outros exemplos de anglicismos grafados em árabe ver pp. 193-194.
} 
Caminhou pela rua Upper Berkley Street em direção à Edgward Road, passando por trás do hotel Cumberland.

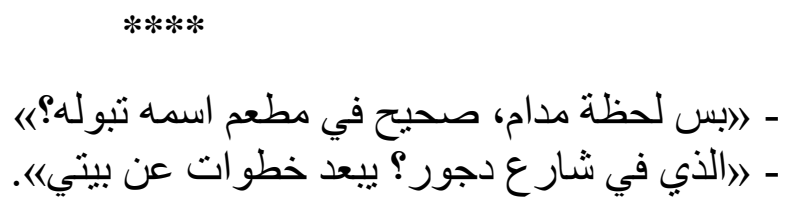

(p. 11)

"Só uma coisa madam, você conhece um restaurante chamado Tabuleh?"

"O que fica na Avenida Djur? Fica a alguns passos da minha casa."

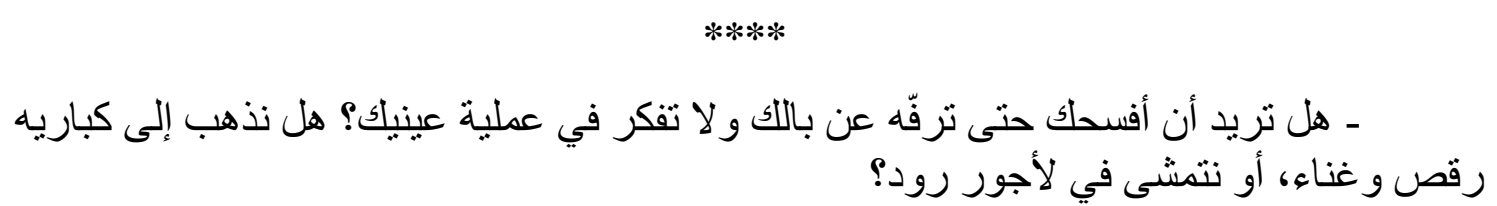

(p. 104)

"Você quer que eu te leve para dar uma volta para vocês distrair sua mente e não pensar na cirurgia dos olhos? Vamos no Cabaré dançar e beber, ou caminhar pela Ajur Road?"

$* * * *$

Nossa interpretação das divergências ortográficas registradas pela autora é de que ela tenha utilizado dessa artimanha para marcar aspectos da pronúncia dos personagens estrangeiros, em contraste com a variação inglesa, grafada em árabe padrão quando mencionado pelo narrador ou personagens ingleses. Por isso, com a intenção de representar esse mesmo fenômeno, como será visto nos trechos expostos, reproduzimos as variações, apenas transliterando as propostas no TP. Esse mesmo fenômeno ocorre com outras palavras, embora com menor frequência, como o carro Rolls Royce, grafado na mesma página de duas maneiras diferentes: الروس رويس) (a r-rūs r rūys)e الرولز رويس (ar-rūlz rūys) (cf. p. 246).

Ao analisarmos as ocorrências de anglicismos, percebemos que eles sempre sucedem ou precedem suas traduções ao árabe, seja da introdução de um trecho musical ou mesmo uma expressão ou palavra inglesa, como observado abaixo:

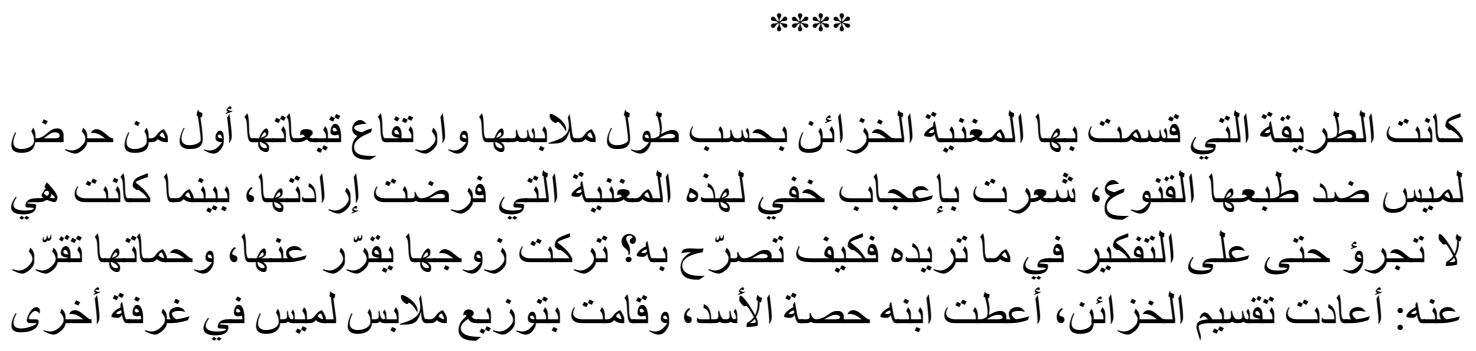




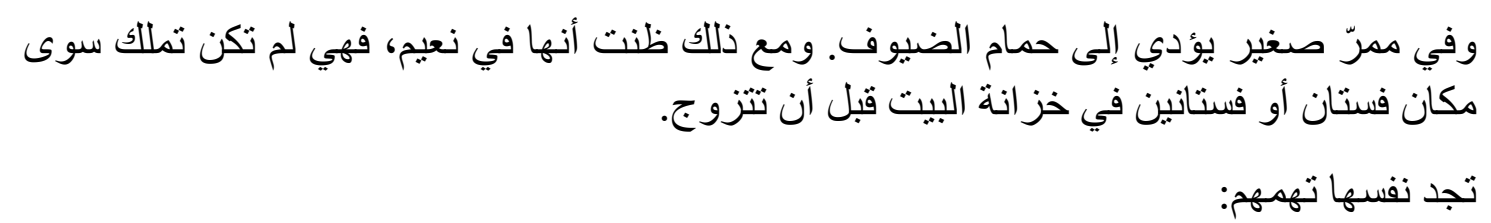

How much is the dog in the window

woof woof

The one with the waggy tail..

Woof woof

كم ثمن هذا الكلب المعروض في الواجهة عوعو الذي يهنّ ذنبه فرحاً.

(p. 19)

Era o modo em que a cantora organizava o guarda-roupas, devido ao cumprimento de suas roupas e a altura de seus chapéus, que primeiro provocou Lamis contra sua natureza conformista. Sentia uma admiração secreta por essa cantora que impunha sua vontade, enquanto ela não ousava sequer pensar no que queria, quanto mais enunciá-lo. Deixava que seu marido decidisse por ela, e sua sogra por ele: reorganizou o guardaroupas. Deu ao seu filho a melhor parte, enquanto as roupas de Lamis foram distribuídas no outro quarto e num corredor que levava ao banheiro de hóspedes. E achou que estaria satisfeita com isso, já que não possuía mais que um nicho para um ou dois vestidos no guarda-roupas de sua casa antes do casamento.

Achou-se cantarolando:

"How much is the dog in the window woof woof The one with waggy tail...

Woof woof."

Quanto custa este cachorro à mostra na vitrine au au? O que balança o rabo alegremente.

$* * * *$

Não obstante a perda estética propiciada pela diferença dos sistemas literários presente no TP, a manutenção do texto em língua inglesa reitera a coexistência de ambos idiomas no cotidiano da personagem. Assim como no texto árabe, na sequência da canção, apresentamos sua tradução livre. Embora a versão inglesa tenha a talvez irremediável perda dessa heterogeneidade linguística, a versão espanhola, Eso es Londres (2002), que poderia representá-la também pela diferença de idiomas, decide apenas destacar o excerto do corpo do texto traduzido ao espanhol, atitude que não se restringe a apenas o excerto em tela, mas se apresenta como prática ao longo de todo o romance (cf. pp. 19, 170, ):

¿Cuanto cuesta esse perro del escaparate?

El que muve el rabo de alegría 
Apesar de a maioria dos anglicismos presentes no texto seguir esse padrão de apresentar sua paráfrase em língua árabe, o excerto que analisaremos em seguida se difere dos demais, por apresentar uma ‘tradução' que pouco tem a ver com sua versão em língua inglesa:

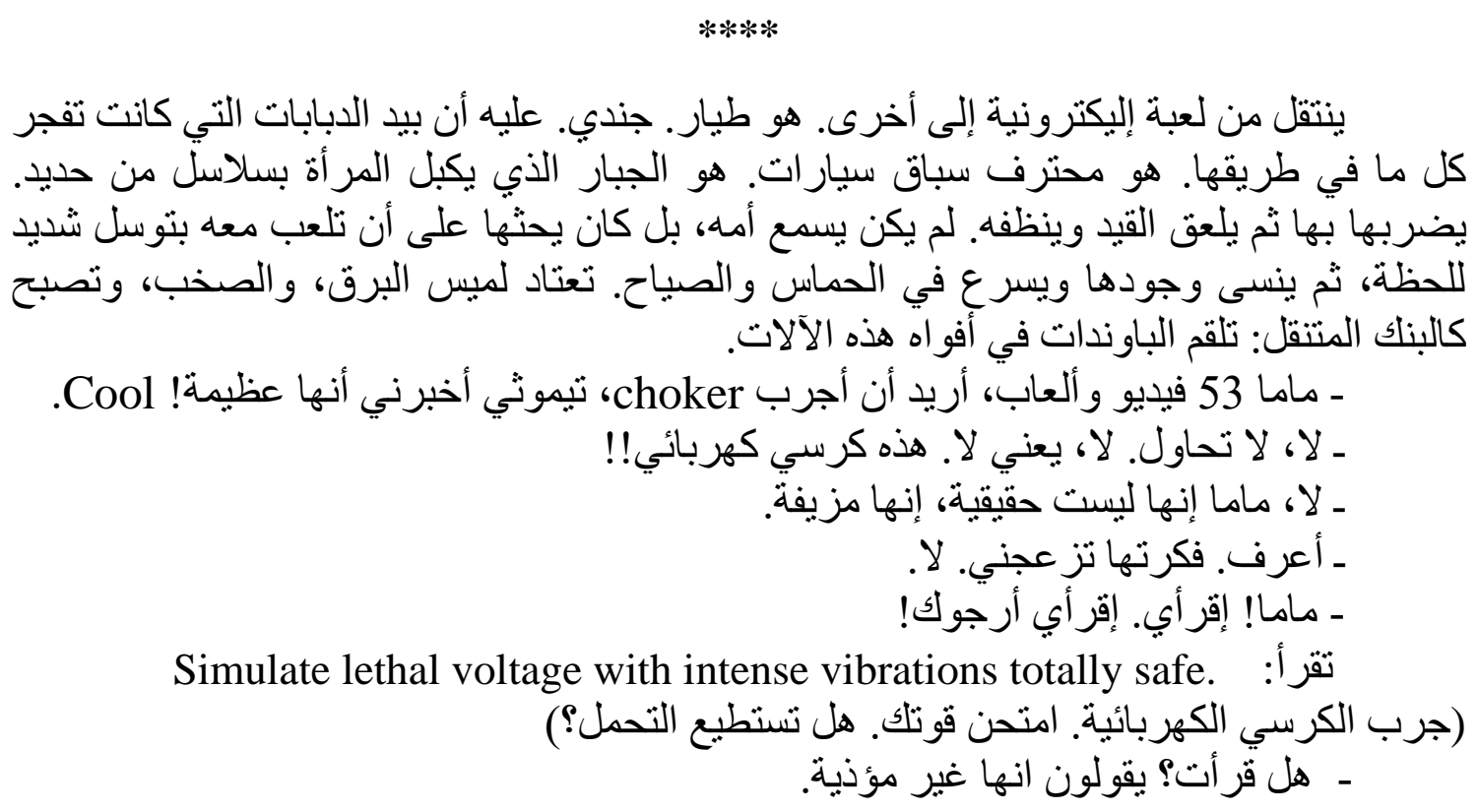

(pp. 194-195)

Passava de um jogo eletrônico a outro. Era um piloto. Um soldado. Tinha que eliminar os tanques que explodiam tudo que havia no seu caminho. Era profissional na corrida de carros. Era um tirano que prendia a mulher com correntes de ferro. Batia-lhe com elas e depois lambia as algemas e as limpava. Não ouvia sua mãe, mas tentava persuadi-la a jogar com ele por um momento, implorando com veemência. Dali a pouco, esquecia-se de sua presença e corria gritando todo entusiasmado. Lamis acostumou-se às luzes e ao barulho e tornou-se um banco ambulante: alimentando as máquinas com uns pounds. Cool!"

"Mama, 53 video-jogos. Eu quero testar o choker. Timothy me disse que é incrível!

"Não, nem tente. Não é não. Isto é uma cadeira elétrica!!!"

"Não, mama, isto não é verdade. Ela é de mentira."

"Eu sei. Mas a ideia dela me incomoda. Não."

"Mama! Leia! Leia! Eu imploro!"

Ela leu: Simulate lethal voltage with intense vibrations. Totally safe.

(Experimente a cadeira elétrica. Teste sua força. Você aguentaria?)

"Você leu? Eles dizem que não faz mal." 
Assim como no trecho que comentamos anteriormente, vemos a ocorrência dos anglicismos precedidos ou pospostos à sua tradução. No entanto, observamos que, na sentença em língua inglesa "Simulate lethal voltage with intense vibrations. Totally safe" - cuja tradução livre seria algo como: "Simule uma tensão letal com intensas vibrações. Totalmente seguro." -, em língua árabe, o texto que funcionaria como sua tradução apresenta-se completamente diferente, qual seja: "Experimente a cadeira elétrica. Teste sua força. Você aguentaria?". Considerando a intencionalidade proposta nesse romance, é possível inferir que a autora tenha sugerido ao seu leitor como ela entende que as traduções são realizadas. Talvez suas experiências com versões de suas próprias obras para outros idiomas tenham lhe mostrado como se dão os processos de transposição de um texto de um idioma a outro, sobretudo no que diz respeito à literatura árabe.

Desse excerto, assim como em outros momentos em que temos diálogos entre Lamis e seu filho (cf. pp. 191-196), podemos perceber que a comunicação é realizada por meio de um dialeto que mistura o árabe com o inglês. Pois, não obstante viva em um ambiente completamente árabe com a família em casa, o garoto está o tempo todo querendo ser parte do universo britânico que existe afora do seio familiar, ao ver o nome de seus amigos - que sugerem sempre uma origem inglesa -, os hábitos britânicos que adota, o estilo de vida que deseja ter etc.

A partir de um registro do dialeto londrino, Al-Shaykh nos envolve com a sensual descrição apresentada pelo narrador da experiência de Lamis com a língua inglesa. Promovendo uma experiência sinestésica para o leitor, a reprodução da grafia que nos remete imediatamente ao som do sotaque londrino, representamos, como em TP, ambas as grafias das palavras inglesas.

\section{$* * * *$}

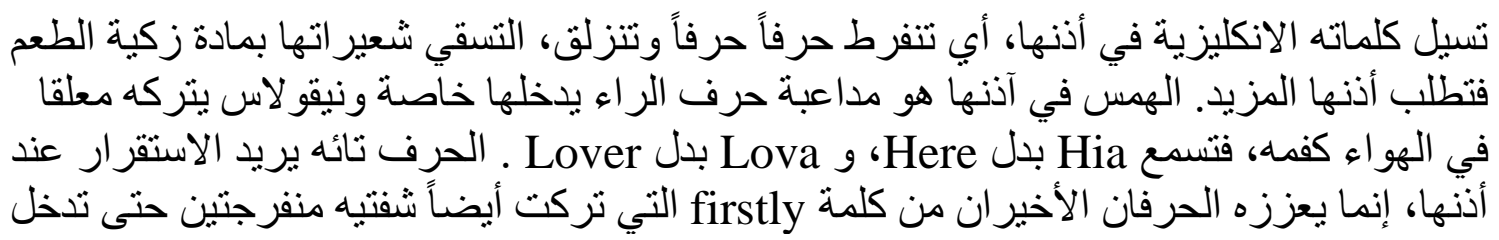
أذنها، إنما يعززه الحرفاء الأخير ان من كلمة firstly التي تركت أيضاً شفتيه منفرجتين حتى تدخل

Suas palavras inglesas fluíam em seu ouvido, dissolvendo-se letra após letra, e escorregavam, regando seus pelos com uma substância de delicioso sabor, então seus ouvidos pediam mais. O sussurrar nos seus ouvidos é o flerte com a letra ' $r$ ' que a penetrava especialmente quando Nicholas deixava-a suspensa no ar como seus lábios. Assim ela ouvia Hia em lugar de Here e Lova em lugar de Lover. A letra perdida queria 
permanecer em seus ouvidos, mesmo quando ele enfatizava as duas últimas letras da palavra firstly que também deixavam sua boca aberta até que Lamis a penetrasse. Assim que sua voz era emitida, ela se aproximava de suas cordas vocais, e as via como as cordas que suspendem as pontes.

$$
* * * *
$$

\section{Expressões religiosas}

No diálogo reproduzido na sequência, nota-se o uso de uma outra variante dialetal que muito se aproxima do árabe fuṣha, a variante padrão, por coincidirem em muitas estruturas e vocabulários. Talvez o uso se deva ao fato de que a conversa ocorre entre Amira, que é marroquina, e um indivíduo a quem a autora refere-se sempre como o 'homem do Golfo', cujos dialetos se diferem em tamanho grau, que é possível que os interlocutores não se compreendam ao fazer uso de sua variante nativa durante a interação.

Percebe-se ainda a recorrência das expressões religiosas e as diferentes significações atribuídas às vezes a uma mesma expressão, dependendo do contexto em que é enunciada. Como, por exemplo, no dialeto egípcio, com o qual normalmente Amira se comunica, embora seja marroquina, a expressão ‘ إن شعاء الله (In ša 'Allah') que, comumente traduzida ao português como 'Se Deus quiser' ou 'Deus queira', é dita com uma frequência altíssima e vai variando seu significado de acordo com a entonação e o contexto de fala, inclusive é enunciada mesmo quando o interlocutor não tem a menor intenção ou não deseja que algo aconteça, ou ainda em contextos que não fazem sentido.

Neste trecho, há também a presença de outras expressões bastante usuais dentre os muçulmanos, tais como: 'باسم الله' (b- 'ism Llah), geralmente traduzido como 'em nome de Deus', 'الحمد لله' (al-Hamd" L'lah), 'louvado seja Deus', sobretudo na fala do 'homem do Golfo'. A repetição dessas expressões, mesmo que presentes na fala dos crentes em geral, aqui, possivelmente, seja para caracterizar a sua origem, região bastante conhecida pela tradição islâmica mais conservadora, muito embora a situação descrita seja considerada extremamente escandalosa e pecaminosa - qual seja, o encontro de um homem de família com uma prostituta em um quarto de hotel. Dada a particularidade de algumas dessas expressões, elas foram traduzidas ao português buscando-se equivalentes já cristalizados na cultura de chegada. 


$$
\begin{aligned}
& \text { - مين مين؟ } \\
& \text { ـ أنا نوال قريية أمبرة. } \\
& \text { ـ ـ أميرة، نسيت شيبئًاً } \\
& \text { ـ لا، نو ال قريبة أمبرة.. }
\end{aligned}
$$

انتظرت ما يقارب الخمس دقائق أونائق أوشكت أن تخبط مرة أخرى، لكنه فتح لها الباب

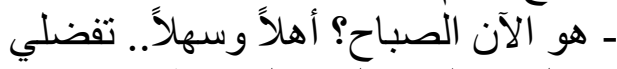

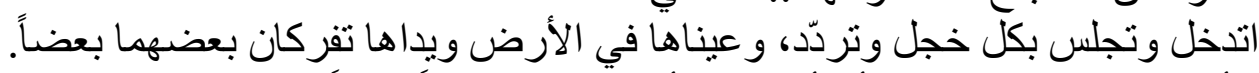

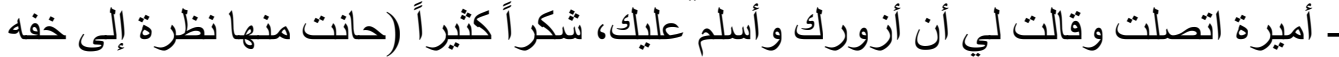

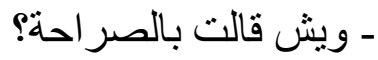

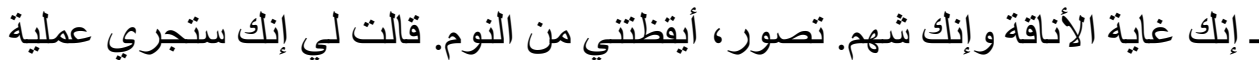

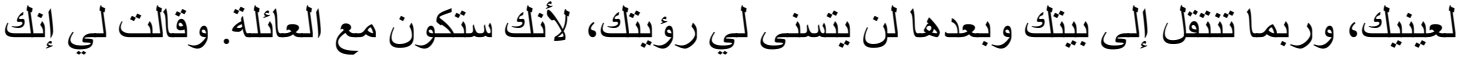
في منتهى الطيبة.

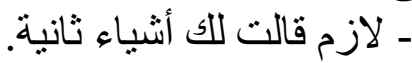

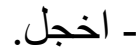

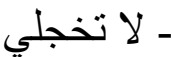
ـ ـ قالت: اسم الله عليك و لا شباب م1 اسنة - لا أثنرب و لا أسكر و لا أخذ أب دو اءو، والضمير مرتاح و الحمد الله، لكن صوتلك يشبه وتها سبحان الله

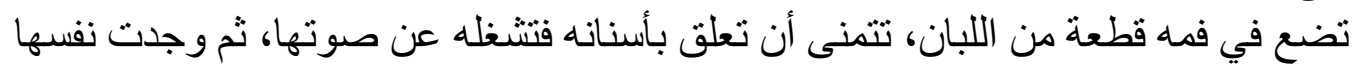

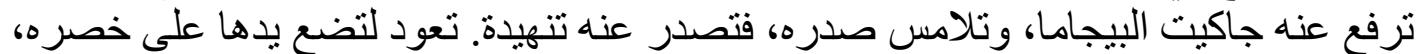

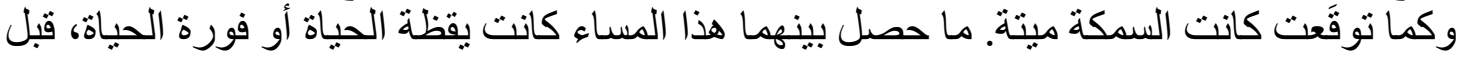

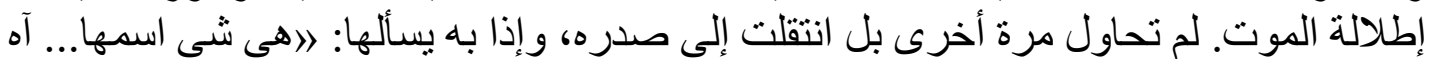

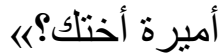

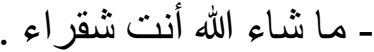
ـ أمي من هو لنداء الندان

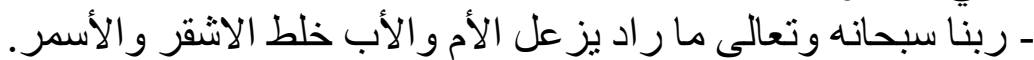

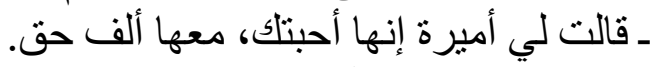

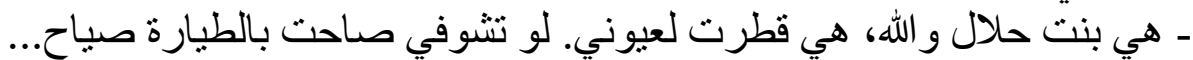

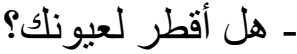

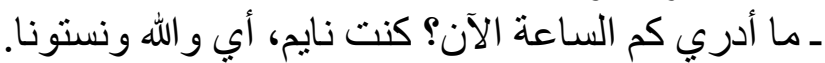

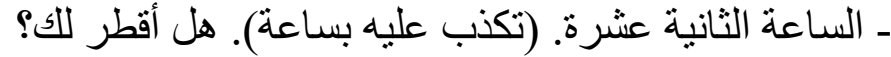

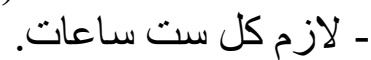
ـ ـ أستناك ساعتين و أقطر للك، أحسن ترناح في السرير

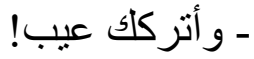
ـ المهم راحتلك.

تتهض، فينهض. لكنه لكنها تجلس فوق السرير وتمد له يدها فيأتي إلى جانبها. ــ إذا قالت أميرة إنها أحبتني، و أنت؟

(pp.107-109) 
"Quem é? Quem é?"

"É Nawwal, parente da Amira."

"Amira, esqueceu alguma coisa?"

"Não, Nawwal parente da Amira.."

Esperou aproximadamente cinco minutos. Estava a ponto de bater novamente, quando ele lhe abriu a porta.

"Seja bem-vinda. Allah, estava dormindo."

"Espero que tenha dormido bem..."

"Já é de manhã? Seja bem-vinda... tenha a bondade."

Entrou e sentou-se tímida e hesitante. Tinha os olhos no chão e esfregava as mãos uma na outra.

"Amira me ligou e disse para eu te visitar e te cumprimentar. Muito obrigada. (Lançou-lhe um olhar para suas elegantes pantufas."

"Sinceramente, o que ela disse?"

"Que você é muito elegante e cavalheiro. Imagine, ela me acordou me dizendo que você fará uma cirurgia nos olhos, e que talvez se mude para sua casa e depois disso não será mais possível que eu te veja porque você estará com a família. Me disse também que você é extremamente bondoso."

"Ela deve ter dito outras coisas."

"Fico constrangida."

"Não fique."

"Benza Deus, me disse inclusive que não tem moço de dezoito anos que te deixe para trás."

"Não fumo, não bebo, nem tomo remédio algum. E tenho a consciência tranquila, Alhamdulillah. Mas como a sua voz se parece com a voz dela, Subhan Allah."

Colocou em sua boca uma goma de mascar na esperança de que grudasse em seus dentes distraindo-o de sua voz. Em seguida, achou-se tirando a camisa de seu pijama e a acariciar seu peito, então suspirou. Agarrou-o pela cintura e, como esperava, o peixe estava morto. O ocorreu entre eles naquela noite foi o despertar da vida, ou a erupção da vida, antes da eminência da morte. Não tentou novamente, mas achegou-se ao seu peito. Então, ele lhe perguntou: "Ela... como se chama?...Ahh... Amira. É sua irmã?

"Não. Minha prima."

"Machah Allah, e você é loira."

"Minha mãe é holandesa."

"Bendito seja Deus! Não desapontou nem a mãe nem o pai, misturou o loiro e o moreno."

"Amira me disse que te adorou, e ela tem toda razão."

"Ela é uma moça direita e filha de Deus Ela pingou colírio em meus olhos. Se você a visse gritando no avião..."

"Quer que eu pingue colírio nos seus olhos?"

"Não sei que horas são agora. Eu estava dormindo, juro, vocês me aliviaram."

"É meia noite. (Mentiu-lhe). Você quer que eu pingue?"

"É preciso a cada seis horas."

"Eu espero duas horas e pingo pra você, é melhor descansar na cama."

"E te deixo, não tá certo." 
"O importante é você descansar."

Ela se levantou e ele seguiu-lhe. Então sentou-se sobre a cama e estendeu-lhe a mão, ele achegou-se ao seu lado.

"Então Amira te disse que me adorou, e você?"

Para a expressão 'اسم الله عليك' (Ism 'Allah 'alayka) - literalmente, 'O nome de Deus sobre você'-, que significa 'que benção', optamos pela tradução da expressão através de um equivalente 'Benza Deus', uma vez que ficaria muito difícil de deduzir seu significado, caso a mantivéssemos. Entretanto, diante de 'الحمد لله (al-Hamd $\left.{ }^{u} L^{i} l a h\right)$, 'Louvado seja Deus', escolhemos a manutenção da expressão com uma transliteração que cause menos estranhamento ao leitor: Alhamdulillah, por se tratar de uma expressão mais difundida e reconhecidamente islâmica. Do mesmo modo, preservamos também ' سبحان الله (Subhan 'Allah) 'Deus seja louvado', uma exclamação que indica admiração, ou surpresa.

Para além das expressões religiosas que nos interessam para análise desse excerto, é preciso apontar que, a despeito de nosso posicionamento ser de não oferecer explicações ao longo da narrativa, especialmente nesse diálogo, fizemos a introdução da palavra 'colírio', pois no TP temos apenas o verbo 'قطر (qatara), 'pingar, gotejar', sem o seu objeto. Assim, fizemos a adição na primeira ocorrência, na fala do 'homem do Golfo', e a elidimos na fala que vem na sequência, enunciada por Amira. Isso porque julgamos que soaria muito estranho e traria uma incompreensão à sentença: "Ela é uma moça direita e filha de Deus. Ela pingou em meus olhos”. Interessante notar que, embora a tradução espanhola se proponha, em diversos aspectos, se manter mais fiel à letra, na passagem "هي بنت حلال والله، (hīa bint ḥalāl wa 'Allah), traduz-se como "Es una buena chica”(p. 98), retendo a ideia de respeitabilidade que contém a expressão "ببنت حلال” (bint halalal $)^{41}$, literalmente 'moça respeitável, decente'.

\footnotetext{
${ }^{41}$ Note-se que, apesar de o vocábulo حلال 'halāl' (permitido, legal, legítimo, lícito) ser, em certa medida, conhecido entre alguns falantes do português brasileiro devido à exportação de produtos do gênero alimentício a países islâmicos, optamos por adotar tradução literal de"بنت حلال" (bint halāal), justamente por sua relação direta na cultura de chegada com a forma de produção de alimentos ou abate animal.
} 


\section{Provérbios e expressões metafóricas}

Como mencionado no início do capítulo, propomos que, mesmo diante de provérbios cujos valores semânticos se correspondam em ambas as línguas, sempre que possível, traremos a imagem representada a partir da língua de partida, a fim de transportar diferenças linguísticas e culturais para a versão final do texto. Do mesmo modo serão tratadas as expressões metafóricas, com vistas a estimular a criação de novas representações no imaginário do leitor de TC.

No excerto reproduzido abaixo, temos o encontro de Amira com a esposa de Samir, que acaba de chegar em Londres, em busca do marido. Ao descobrir que Samir estava morando com uma mulher e não com homens libaneses, a personagem faz um comentário preconceituoso ao confundir a nacionalidade de Amira.

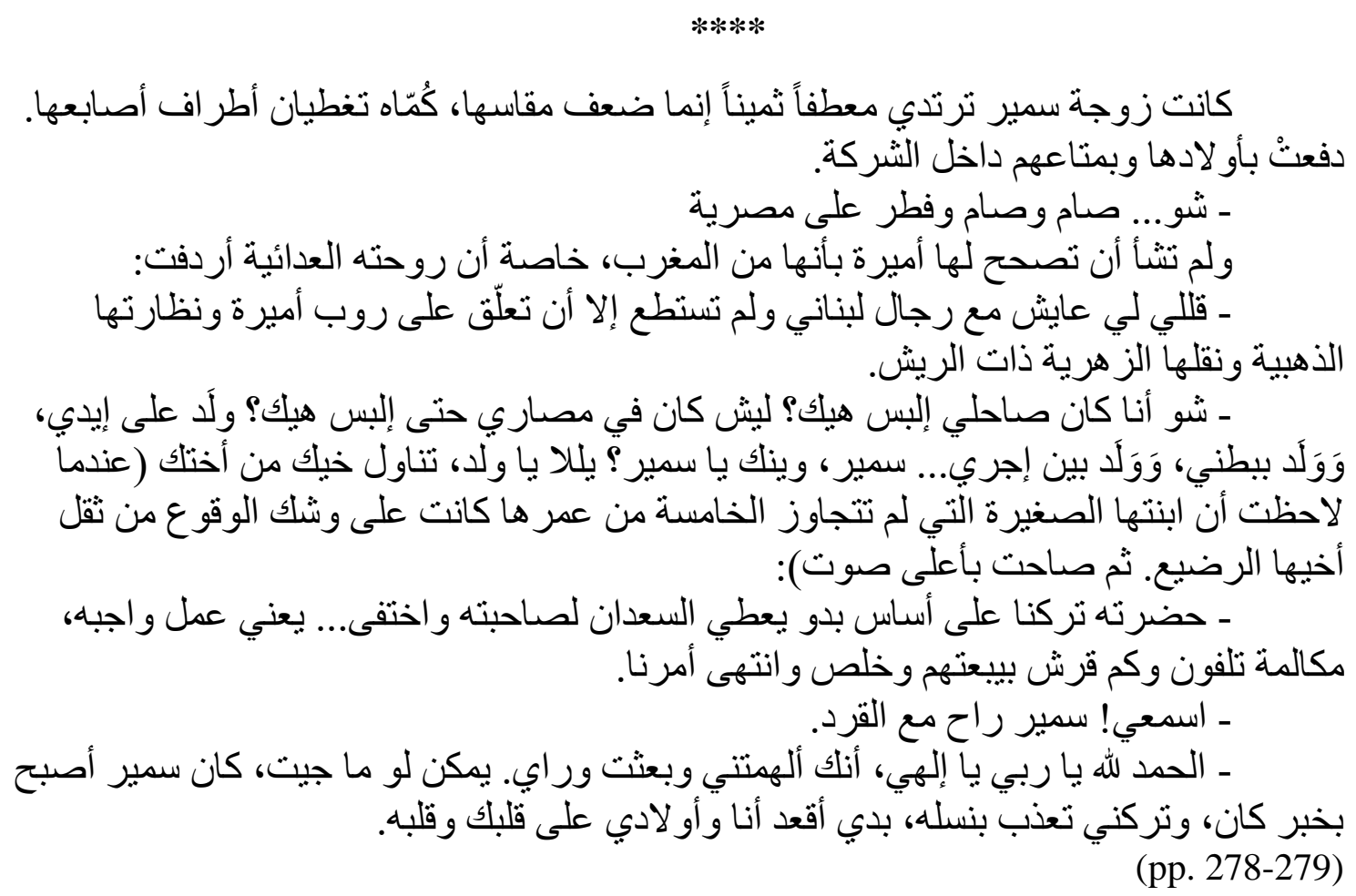

A esposa de Samir vestia um casaco caro, embora fosse duas vezes maior que o seu tamanho, suas mangas cobriam parte de seus dedos. Meteu-se no apartamento com as crianças e as malas.

"O que... jejuou, jejuou para comer uma egípcia."

Amira não quis explicar-lhe que era do Marrocos, principalmente porque a hostil esposa de Samir acrescentou:

"Tinha me dito que vivia com um homem libanês..."

Não resistiu tecer um comentário sobre o robe de Amira, seus óculos dourados e seus chinelos de pluma rosa.

"Ué, eu podia me vestir assim? E tinha dinheiro para me vestir assim? Tinha era um menino nas mãos, outro na barriga e outro entre as minhas pernas... Samir, onde você 
tá, Samir? Yallah, menino, pega seu irmão do colo da sua irmã." Disse quando percebeu que sua filhinha que ainda não tinha cinco anos estava a ponto de cair com o peso do bebê, em seguida gritou:

"O senhor deixou a gente dizendo que queria entregar o macaco pro dono e desapareceu... quer dizer, já fez sua obrigação... uma ligação telefônica, uns trocados e pronto. Acabou."

"Me escuta! Samir se foi com o macaco."

"Alhamdulillah, meu senhor, ya Ilahy, ainda bem que me alertou e me guiou até aqui pra que eu enxergasse. Se eu não tivesse vindo, Samir tinha era virado notícia. Me deixou sofrendo com a cria dele. Eu e meus filhos vamos ficar em cima de vocês. Vocês não vão se livrar da gente".

$* * * *$

No calor das emoções causadas pelo encontro inesperado, Isa āa lança mão de uma expressão muito popular entre a comunidade muçulmana, dada sua relação direta com um rito previsto pela religião: o jejum. Durante o mês do Ramadã, os crentes normalmente jejuam do nascer ao pôr do sol. Nesses dias, as refeições realizadas no desjejum, dentro das possibilidades de cada indivíduo, são sempre constituídas pelos melhores pratos. Geralmente, para o desjejum, as famílias recebem grupos de amigos e familiares para celebrarem juntos.

Uma vez contextualizada a fala da personagem - شو... صام وصام وفطر على مصرية ( $\check{\text { š }}$... șâma wa șâma wa fațara 'ala miṣrya), literalmente 'que... jejuou, jejuou e desjejuou uma egípcia' -, observamos que, além da referência direta ao rito religioso, há aqui, também, o menosprezo com relação a nacionalidade da mulher egípcia. Com intenções de introduzir essa referência cultural-religiosa, optamos pela manutenção do verbo

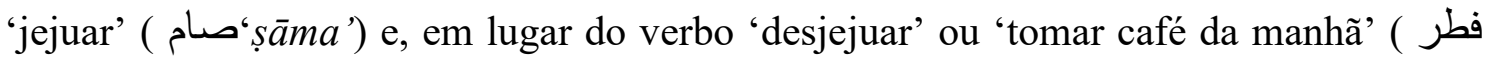
'fațara'), usamos o verbo 'comer', que, no português traz a ambiguidade de 'fazer uma refeição' e do 'ato sexual', como é o caso da proposta em árabe.

Nesse mesmo trecho, também enunciado por Isa āaf, temos uma outra expressão que é bastante recorrente em língua árabe: بدي أقعد أناو أو لادي على قلبك وقلبه (bedī 'iq 'ud 'anā wa 'awlādī 'alā qalbik waqalbuh), literalmente 'eu quero me sentar eu e meus filhos sobre o seu coração e o coração dele'. Trazendo em si um sentindo de importunar, ou no popular 'ficar em cima', decidimos por traduzir o trecho como: 'Eu e meus filhos vamos ficar em cima de vocês. Vocês não vão se livrar da gente', em que 'ficar em cima' se aproxima, em alguma medida, do proposto em árabe, ao passo que 'não vão se livrar da gente' enfatiza a ideia de importunação. 
Na passagem que se segue, temos três exemplificações de provérbios enunciados pela personagem Lamis. Em uma tentativa de explicar sua impressão a respeito do encontro fortuito com o britânico Nicolas, a iraquiana faz menção de um provérbio árabe.

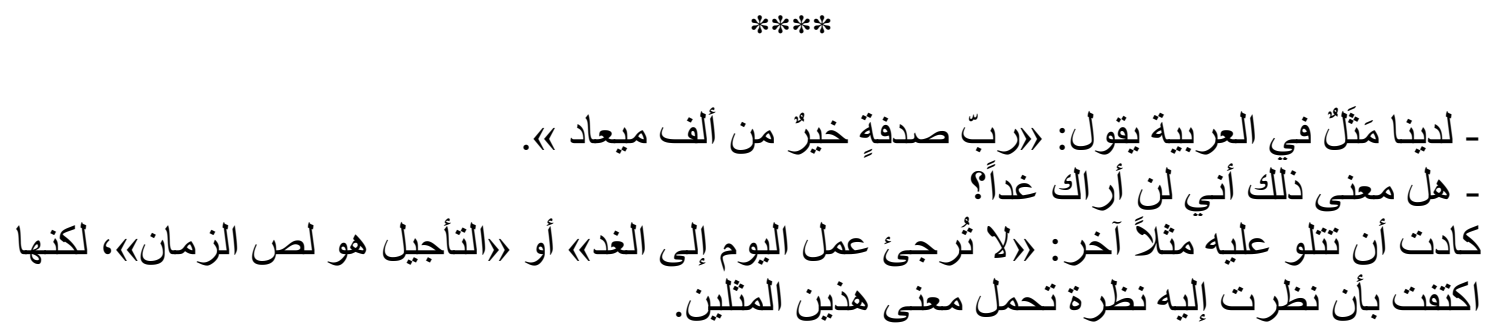

(p.148)

"Nós temos um provérbio em árabe que diz: 'a casualidade divina é melhor que mil encontros marcados"".

"Você quer dizer com isso que não nos encontraremos amanhã?"

Quase lhe recitou outro provérbio: "não deixe para amanhã o que você pode fazer hoje' ou 'a procrastinação é ladrão do tempo', porém satisfez-se em somente lhe lançar um olhar que valia pelos dois provérbios.

$* * * *$

Em ربّ صدفةٍ خيرٌ من ألف مبعاد (rabb ṣudfat hayr min 'alf mī'aād), 'a coincidência de Deus é melhor que mil encontros marcados', decidimos por uma tradução também mais próxima do original. No entanto, nos valemos do trocadilho 'causalidade divina' (divina providência) e 'casualidade divina', com vistas a dar essa ideia de providência divina, sem nos distanciarmos de 'coincidência e fortuidade' guardada no vocábulo árabe صدفة (ṣudfat). Os demais provérbios enunciados pela personagem, لا تُرجئ عمل اليوم إلى الغد : coincidentemente, têm correspondentes diretos no portuguêss (Lā turji' 'amal al-yūm 'ilā al-gad), 'não posponha o trabalho de hoje para amanhã', traduzido na versão cristalizada do PB 'não deixe para amanhã o que você pode fazer hoje' e التأجيل هو لص الزمان (al-ta 'ajīl huwa liṣṣ al-zamān), 'a procrastinação é ladrão do tempo', que foi mantida no seu formato literal, dada sua correspondência exata em PB.

O excerto analisado em seguida também traz um provérbio com um correspondente em língua portuguesa, mas que julgamos ser mais interessante a manutenção da imagem proposta na língua de partida, por, em alguma medida, nos sugerir uma profundidade conceitual mais ampla. 


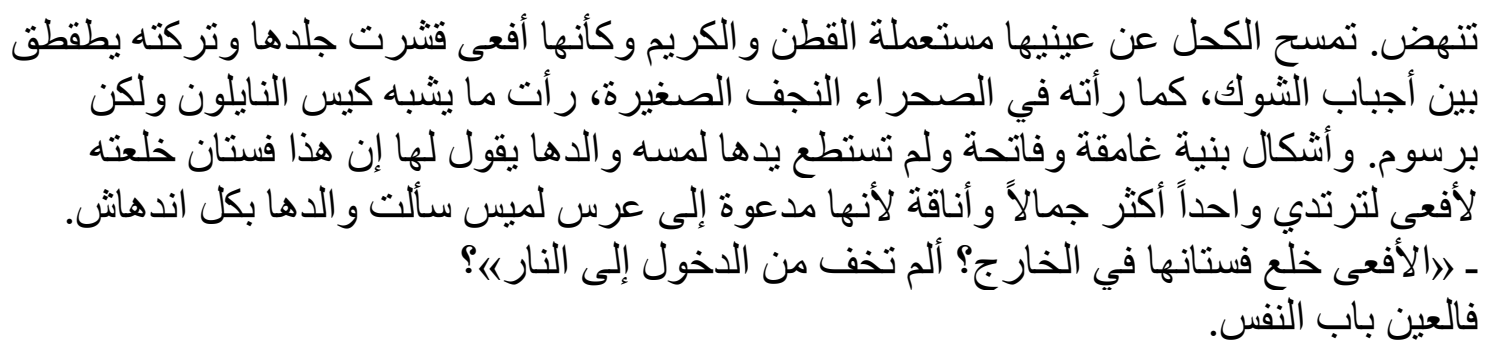

Levanta-se. Limpa o kohl dos olhos com algodão e creme, como uma serpente que se livra da pele deixando-a estalar entre os cactos, como havia visto no deserto de Najaf, quando pequena. Vira uma pele que se parecia uma sacola plástica, mas com desenhos e formas marrom escuro e claro, e não podia tocá-la.

Seu pai disse-lhe que a serpente havia tirado esse vestido e usaria outro que fosse mais bonito e mais elegante, pois havia sido convidada para um casamento.

Lamis perguntou ao seu pai com todo deslumbramento:

"A cobra tirou seu vestido aqui fora? Não tinha medo de ir para o inferno?"

Pois o olho é a porta da alma.

$$
* * * *
$$

Apesar de haver no português o provérbio 'os olhos são a janela da alma' que, de certo modo, daria conta do sentido proposto em فالعين باب النفس (fa-l- 'ayn bāb al-nafs) - literalmente, "pois o olho é a porta da alma" -, demos preferência à formulação em árabe, para que se acesse a singularidade contida no texto de partida, e, devido à semelhança entre as formulações das expressões em árabe e em português, acreditamos que a relação será facilmente realizada pelo leitor.

Do mesmo modo, operamos com o provérbio seguinte:

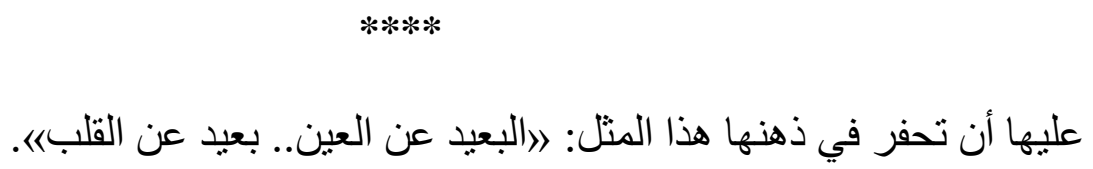

Ela tinha que entalhar em sua mente este provérbio: 'longe dos olhos... longe do coração’.

$* * * * *$

Mesmo havendo um corresponde direto para o provérbio: البعيد عن العين.. بعيد عن (al-ba īd 'an al- 'ayn.. ba ìd 'an al-qalb) , 'longe do olho... longe do coração', cristalizado na forma 'o que os olhos não vê o coração não sente', optamos pela 
manutenção da versão mais próxima do árabe, considerando nosso posicionamento de 'compensar' a perda da diferença dos sistemas de escrita, por exemplo, em outros níveis linguísticos, isto é, acreditando que a compreensão não será prejudicada e o incômodo proposto em PB, será, em alguma medida, reproduzido.

\section{Aspectos Culturais}

Como reiterado ao longo desse trabalho, o romance por nós discutido nos parece ter por um dos principais objetivos representar o encontro de culturas sob diversos prismas e, apesar de ser muito bem trabalhado no nível linguístico, a autora também se comprometeu a explorar diferentes referências culturais, tanto do universo inglês como do árabo-islâmico ${ }^{42}$. Ao lançar mão de elementos de ambas as culturas, Al-Shaykh demonstra um domínio da cultura europeia que nos parece ser uma marca da literatura pós-colonial. Para além de citar detalhes da tradição islâmica, da literatura árabe clássica e moderna, também menciona minúcias da cultura britânica, assim como detalhes da cidade de Londres, os quais quem nunca a visitou ou terá dificuldades de imaginá-los ou passarão despercebidos, tudo isso sem qualquer explicação no texto ou por meio de nota para situar o leitor.

Considerando essa postura da autora em não mediar ambas as culturas através de esclarecimentos ou qualquer tipo de elucidação de suas referências, optamos por, do mesmo modo, apresentá-las sem este aparato, a fim de reproduzir o mesmo desconforto ou até maior que o proposto -, já que o texto em língua portuguesa prevê uma terceira cultura, alheia às aludidas em TP. Destarte, como veremos adiante, mantivemos os elementos da tradição islâmica representados nesse excerto, como o divórcio do triplo

\footnotetext{
${ }^{42}$ A despeito de a autora querer explorar amplamente a multiculturalidade árabe, notamos que, embora haja uma boa parcela árabe que professe a fé cristã, esta não foi representada nesse romance através de nenhum personagem, por isso nossa insistência em sempre contrapor à cultura britânica a cultura árabo-islâmica. Cabe ainda mencionar que alguns dos personagens cristãos da obra, todos britânicos, estão sempre mencionando a necessidade de se cristianizar os muçulmanos ou ainda que a igreja cristã é o lugar para todas as religiões e para todos os refugiados e necessitados. O primeiro caso é ilustrado no episódio em que o pai de Nicolas, em uma de suas conversas com o filho, pergunta se ele, ao viajar para o Omã levou o Evangelho em língua árabe consigo, para entregar ao seu empregador muçulmano, com o intuito de o evangelizar. Nicolas, representando a geração europeia mais jovem, mostra-se completamente indiferente a esse ideal bastante forte no período colonialista, ao deixar o livro sagrado abandonado em uma mesa (cf. p. 23). O outro caso é representado por um padre que recebe a esposa de Samir que, desesperada e abandonada pelo marido, está em Londres com os cinco filhos, e busca por ajuda financeira (cf. p. 366).
} 
talā $q^{43}$, embora tivéssemos ainda como opção 'triplamente divorciado' ou 'divórcio irrevogável, forma mais conhecida em PB.

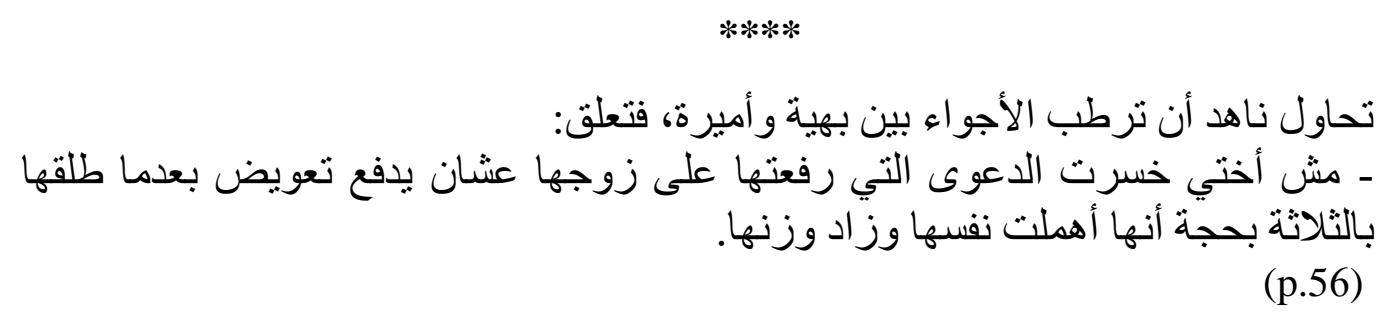

Nahid tentou apaziguar os ares entre Bahia e Amira, comentando:

"Minha irmã perdeu o processo que ela levantou contra o marido para que ele pagasse uma indenização depois do divórcio do triplo talaq porque ela deixou de se cuidar e engordou."

$* * * *$

Por se tratar de um texto que, originalmente, prevê uma comunidade leitora de língua árabe e, portanto, familiarizada com elementos da tradição e cultura áraboislâmica, não se espera que a autora se preste a muitas explicações com relação a esse tópico. No entanto, há um único momento em que ela o faz através de nota de rodapé: o episódio ocorre quando Lamis e Nicolas vão à British Library, e ele solicita uma cópia de um manuscrito em árabe e ambos passam a uma sala repleta de "acadêmicos debruçados no trabalho investigativo como se não deixassem o prédio por eras” (p.181). Em posse do manuscrito, Lamis lembra-se de que Nicolas não lê o árabe e entende que ele lhe pedirá que o leia:

Não sabia a razão da ansiedade. Não havia aprendido as declinações gramaticais e a sintaxe. Não se dava muita importância para isso nas escolas de Damasco e Beirute: 'tudo bem, eu vou ler sem as declinações se ele me pedir' [...] (p. 181).

Ao perceber que poderia ler o texto sem grandes dificuldades, lembra-se do que certa feita ouviu de sua avó: "Não acredito que a língua árabe continua a mesma por

\footnotetext{
${ }^{43}$ Regime de separação adotada por algumas comunidades islâmicas, que garante a separação ao marido que enunciar por três vezes a palavra talāq como uma forma de repúdio à sua mulher. Ao enunciar a palavra por duas vezes, é possível reverter a situação; assim que declarada pela terceira vez, o divórcio torna-se irrevogável. Daí algumas traduções para o português como 'divórcio irrevogável'.
} 
centenas de anos" (p. 183), e dos manuscritos dos quais o avô lia-lhe as palavras que pareciam desenhos:

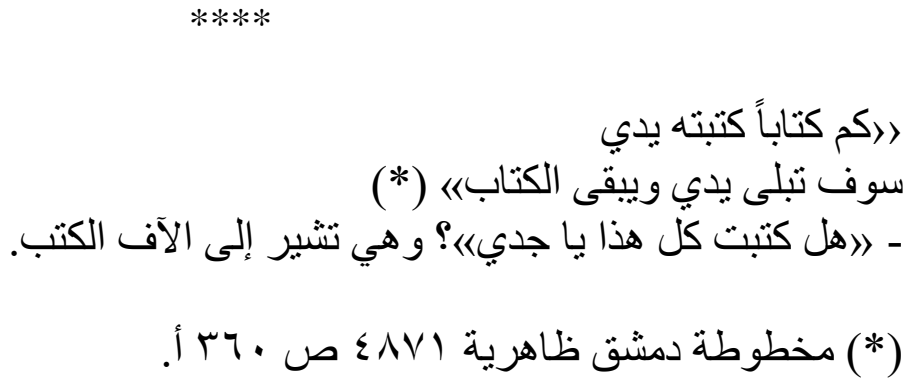

(p.184)

"Quantos livros escreveram minhas mãos?

Envelhecerão minhas mãos e permanecerá o livro" *

Você escreveu tudo isto, vovô? Disse enquanto apontava para milhares de livros.

* Manuscrito de Damasco, Zhahirya, 1784, p. 360 a (N. do A.)

$* * * *$

É interessante notar que, muito embora a autora faça referências a outras obras árabes, como veremos mais adiante no caso da menção à poesia de Adonis, apenas neste excerto há uma nota que corresponde à referência do manuscrito e, ainda neste mesmo episódio, Nicolas solicita na biblioteca um tratado sufista apresentando sua exata localização ${ }^{44}$. Ao nos depararmos com a introdução dessas informações, nos indagamos se seria esse um mero rigor acadêmico manifesto pela autora, ou, para além disso, se ela estaria sugerindo ao seu leitor que sua obra não se restringe apenas ao domínio ficcional, mas, em certa medida, apresenta um valor documental?

Um outro ponto que nos chamou atenção é o fato de que Al-Shaykh cuida de trazer para o seu texto a diglossia existente nos países árabes, e explicita um fenômeno bastante recorrente entre os árabes que aprendem a forma padrão do árabe como segunda

\footnotetext{
${ }^{44}$ British Library: OR5323 (Painting the stars in a century of change: a thirteenth-century copy of Al-Sufi's treatise on the fixed stars). Disponível em: $<<$ http://explore.bl.uk/primo_library/libweb/action/display.do?tabs=moreTab\&ct=display\&fn=s earch \&doc $=$ BLL01011724751\&ind $\mathrm{x}=1 \&$ recIds $=$ BLL01011724751\&recIdxs $=0 \&$ elementId $=0$ \& renderMode=poppedOut $\&$ displayMode $=$ full $\&$ frbrVersion $=\& \mathrm{frbg}=\& \&$ dscnt $=0 \&$ scp $. \mathrm{scps}=$ scope \%3A\%28BLCONTENT\%29\&vl(2084770704UI0)=any \&tb=t\&vid=BLVU1\&mode=Basic\&srt $=$ rank\&tab=local_tab\&dum $=\operatorname{true} \& v l($ freeText0)=OR5323\&dstmp $=1560020258401 \gg$
} 
língua, caracterizada pela declinação, diferentemente do dialeto. Ao leitor que desconhece essa particularidade do idioma a alusão passa completamente desapercebida.

Um outro fato da língua árabe registrado no romance por Hanan Al-Shaykh é a realidade do estrangeiro que aprende o idioma, geralmente, na sua variante padrão e, em alguns casos, considera sua variante dialetal como uma forma de menor prestígio da língua.

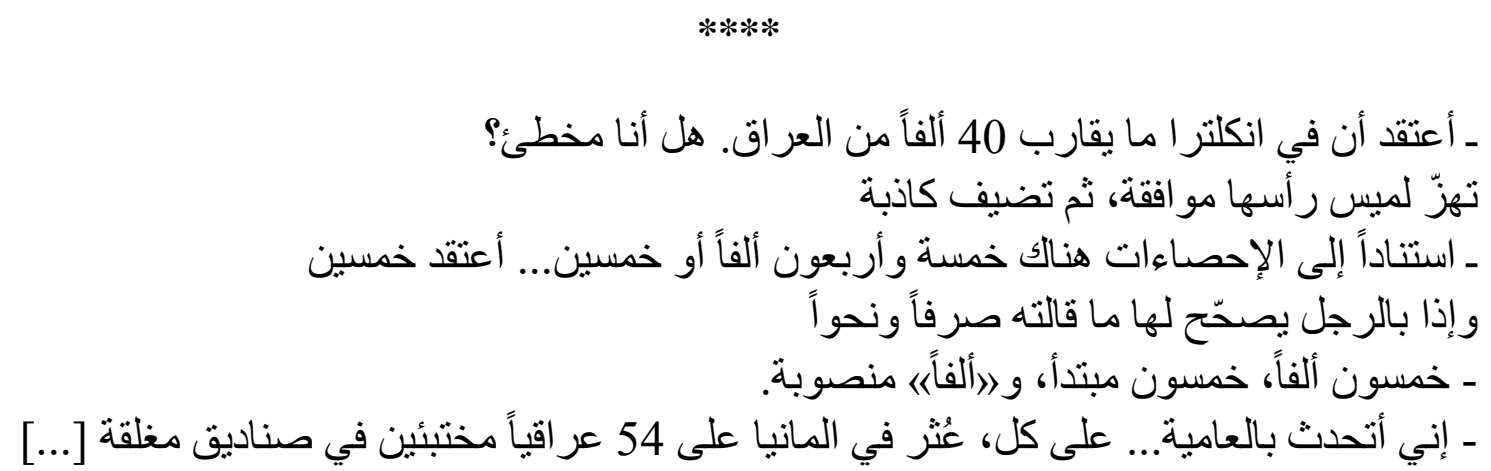

(p. 227) enganado?"

"Acredito que na Inglaterra há aproximadamente 40 mil iraquianos, ou estou

Lamis meneou a cabeça concordando, mas comentou mentindo:

"De acordo com as estatísticas tem 45 ou 50 mil. Acho que 50..."

O homem então logo corrigiu-lhe a declinação e a sintaxe:

"Cinquenta mil. Khamsuna Alfan: Khamsun é o cardinal das dezenas com morfema de plural regular no nominativo, mubtada, e Alfan é o numerado que segue no acusativo singular, mansuba."

"É que estou falando em dialeto... enfim, foram descobertos na Alemanha quarenta e cinco iraquianos. Khamsa wa arb 'auna 'iraqyan escondidos em containers trancados - disse dessa vez em árabe escorreito - [...]."

$* * * *$

Ao tecer uma crítica a uma situação bastante recorrente entre nativos de língua árabe e estudantes estrangeiros, que costumam ser demasiadamente pedantes em determinadas situações, nesse trecho, Al-Shaykh ilustra a circunstância através de um diálogo entre Lamis e um britânico, em um jantar entre amigos oferecido por Nicolas em seu apartamento. Para além da relevante crítica proposta pela autora, o excerto é significativo para a discussão, dada a dificuldade de expressar a 'aula de gramática' oferecida pelo europeu, que deseja revelar um conhecimento preciso sobre a língua árabe à personagem iraquiana. 
Quando o personagem corrige a declinação na fala de Lamis, ele faz referência a termos gramaticais específicos da língua árabe que classificam morfologicamente cada uma das duas partes que compõem o número, como se segue: خمسون ألفاً (Hamsūn 'Alfan), cinquenta mil: خمسون (Hamsūn) 'cinquenta', seria o مبتدأ (mubtad'a), o substantivo no nominativo; e ألفاً ('Alfan) 'mil', o elemento seguinte no acusativo, no caso منصوبة (manșūba) 'acusativo'. Diante do impasse de representar no português a proposta de TP, decidimos adotar o procedimento da própria autora quando se utiliza dos anglicismos. Deste modo, colocamos o número por extenso em português seguido pelo árabe e as terminologias com suas devidas explicações, repetindo a mesma forma na resposta de Lamis.

Nesse mesmo episódio, a autora apresenta uma outra crítica discutida extensivamente pelo Orientalismo de Said (2006), qual seja, o conhecimento sobre o Oriente difundido na comunidade europeia por meio de acadêmicos e escritores orientalistas, que pretendem, por meio de seu discurso, legitimar o colonialismo e a exotização dos povos orientais. Através de uma personagem britânica que aborda Lamis, perguntando-lhe se a moça conhece Pierre Loti, Al-Shaykh nos parece reproduzir em sua narrativa o mesmo que propôs Said (2006) em sua obra: a compreensão do europeu sobre o Oriente é totalmente baseada no trabalho de acomodação dos povos árabes num sistema de representações tendenciosas:

Lamis, você conhece Pierre Loti? Pierre Loti quem me fez amar a Arábia, especialmente quando fala sobre o cheiro de lá, ele diz: 'é o cheiro do almíscar, vibrante e delicioso. Ele aumentou o meu entusiasmo para visitá-la (p. 232).

Uma vez contextualizada a situação em que o nome do escritor francês é mencionado - a quem é reputada uma tendência colonialista e de figuras exóticas- , tornase manifesta a intenção de Al-Shaykh de seguir a linha da crítica orientalista de Said (2009, p. 229), que descreve as narrativas de Loti como histórias "baseadas no ânimo e interesse pela aventura no mundo colonial, longe de lançar dúvidas quanto à iniciativa imperial, servem para confirmar e celebrar seus êxitos."

Outra referência importante, que a escritora traz por meio de um personagem britânico, é a ópera Aida, escrita pelo famoso compositor italiano Giuseppe Verdi, também em meados do século XIX: 
Lamis entendeu o homem a quem conheceu, na Opera House, durante a apresentação da Ópera Carmen, quando soube que ela era árabe e perguntou-lhe se ela gostava de 'Aida'? Foi no contexto da conversa que ela compreendeu que havia uma ópera chamada Aida. Ele quase convidou-a para assisti-la com ele (p. 29).

Bastante explorada por Said (2009), a ópera de Verdi é considerada pelo teórico “uma ópera não sobre, mas da dominação imperial”. A famosa ópera 'egípcia' é considerada um espetáculo teatral, musical e visual, cumprindo a agenda da cultura europeia quando confirma o Oriente como um universo totalmente exótico, distante e antigo no qual os europeus têm licença para a exibição de sua força.

Se interpretarmos Aida dessa perspectiva, cientes de que ela foi escrita e apresentada primeiramente num país africano com o qual Verdi não tinha qualquer ligação, irão se patentear vários traços novos (p. 147).

Por meio de nossa leitura do texto e de sua natureza, bem como de nosso conhecimento da admiração que a autora nutre pelo crítico literário e intelectual palestino $^{45}$, entendemos claramente sua sutil colocação, que, possivelmente, passará desapercebida ao leitor médio que não disponha do conhecimento acerca do debate orientalista, sobretudo por se tratar de obras ignoradas pela própria personagem árabe e ser parte do universo cultural apenas de sua contraparte europeia. No entanto, assim como Al-Shaykh, optamos por não subestimar a capacidade intelectual e curiosidade do leitor, que pode ser movido por um interesse em buscar esclarecimentos sobre as tão recorrentes referências externas introduzidas pela autora.

Na passagem seguinte, como em diversas outras ao longo do romance, a autora reitera a falta de um conhecimento genuíno do britânico em relação aos países do oriente médio, apenas baseados em estereótipos reproduzidos aleatoriamente, a ponto de fazerem confusões demasiadamente grosseiras, tais como equivocarem-se sobre as origens dos estados israelense e árabes.

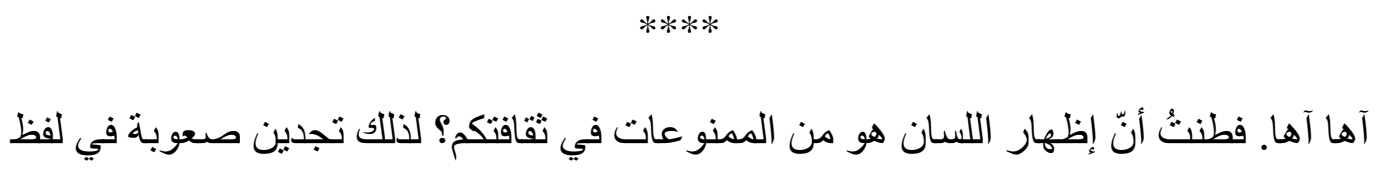

\footnotetext{
${ }^{45}$ Hanan Al-Shaykh, diversas vezes, confessa sua admiração, não apenas, pelo intelectual Edward Said, mas por sua pessoa. Considerado um amigo, a autora menciona em entrevistas o quanto os trabalhos de Said influenciaram diretamente suas obras e como o crítico literário tornou-se uma esperança para a história dos povos árabes (cf. AL-SHAYKH, 2005).
} 


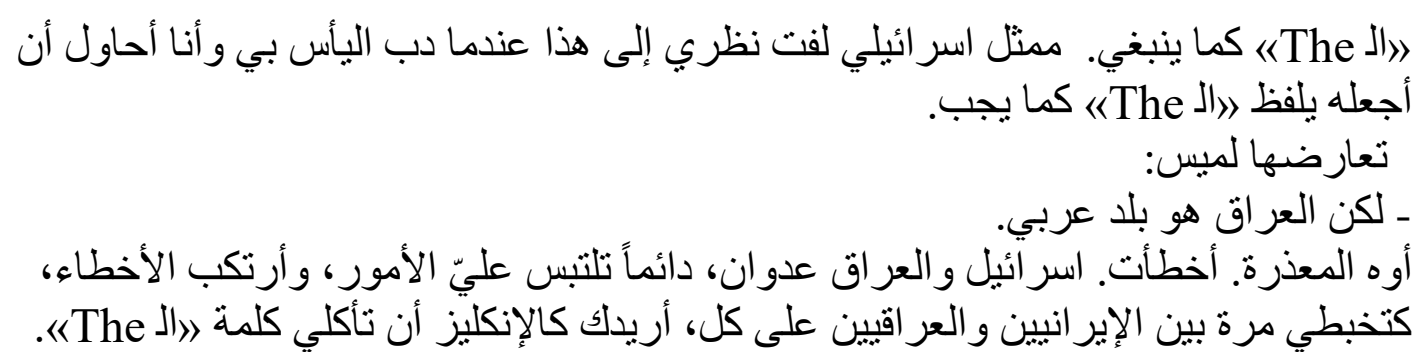
(p.140)

"Aha, aha. Fiquei sabendo que mostrar a língua é uma das proibições da cultura de vocês. Por isso que você encontra dificuldades na pronúncia do The como deveria. Um ator israelense chamou minha atenção para isso quando fui acometida por um desapontamento enquanto tentava fazê-lo pronunciar o The como se deve."

Lamis objetou-a:

"Mas o Iraque é um país árabe."

"Ah, me desculpe. Me enganei. Israel e Iraque são inimigos. Essas coisas são sempre confusas para mim, e eu me equivoco, como uma vez eu fiz confusão entre iranianos e iraquianos. De qualquer forma, eu quero que você, como os ingleses, engula a palavra The." (p.140)

$$
* * * *
$$

Para além das referências que corroboram seu posicionamento em relação à postura orientalista europeia, Al-Shaykh também usa o espaço do romance em defesa da língua árabe - pela qual nutre tanto apreço -, quando introduz ao seu público leitor as palavras de Adonis. Considerado o expoente máximo da poesia árabe contemporânea, o pensador e ensaísta, que renovou a poesia moderna, encontra espaço na fala do pai de Lamis; tocador de alaúde e originário dos pântanos iraquianos, o personagem aqui figura a nostalgia e a afeição pela língua e cultura árabe:

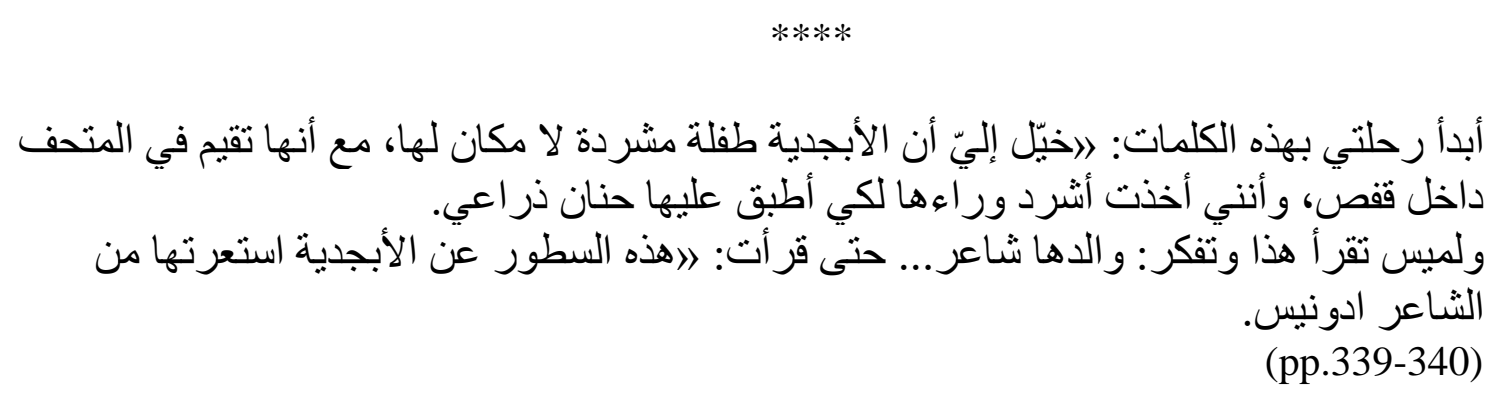

Inicio minha jornada com essas palavras: 'pareceu-me que o alfabeto é como uma criança sem-teto, não há abrigo para ela, embora habitasse no museu, dentro de uma jaula, então eu começo vagar atrás dela para que eu a envolva na ternura de meus braços.'

Lamis leu isto e pensou ser seu pai um poeta... até que leu: 'estas linhas sobre o alfabeto tomei emprestadas do poeta Adonis'. 
Ainda com vistas a dar voz ao indivíduo árabe por vezes silenciados, Al-Shaykh reitera o discurso das escritoras árabes, que remonta à emergência do gênero romance no mundo árabe, ao assumirem-se enquanto ser humano, a despeito de sua nacionalidade e gênero. Por meio da prostituta marroquina, a autora reclama a individualidade do sujeito negada à mulher, tanto na cultura e tradição árabe quanto no Ocidente.

تنهض أميرة بعد أن تسأله هل من كأس ثانية؛ يسمع قرقعة الثلج و إذا بها تمسك منكبيه فجأة تفركهما.

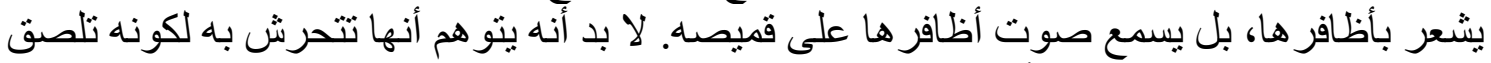

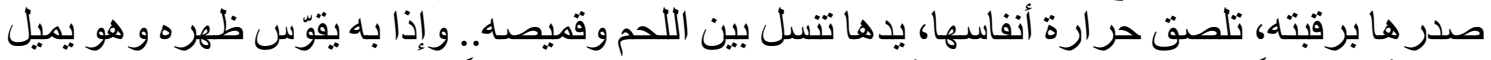

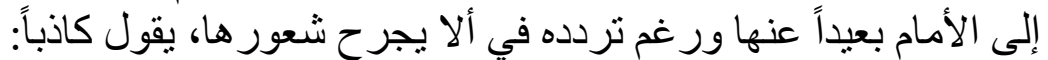

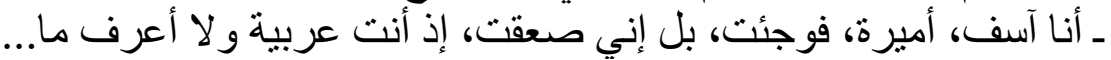

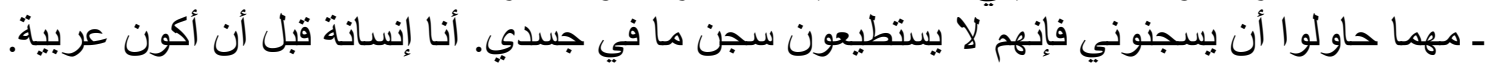

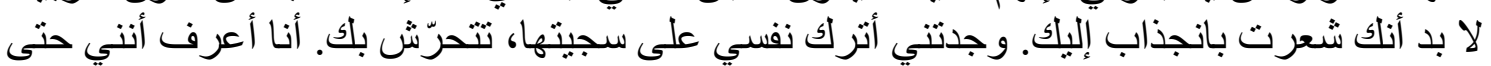

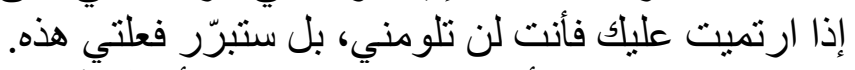

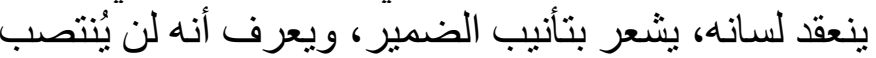
ـ أعرف، أعنا أسف لأني... - أن الرجل ليس كالمظلة الأوتوماتيكية يُضغط زرُ ها فينتصب. (pp.74-75)

Amira levantou-se depois de lhe perguntar: que tal um segundo copo? Nicholas ouvia o estalar do gelo quando repentinamente ela agarrou seus ombros e os massageou. Sentia suas unhas, aliás, ouvia até o som das suas unhas em sua camisa... deveria ter suspeitado que ela o seduziria. Estava com o peito colado em sua nuca, podia sentir o calor de sua respiração, sua mão infiltrava-se entre sua pele e sua camisa... então ele arqueou suas costas, inclinando-se para frente e distanciou-se dela. E, apesar de sua relutância em não querer ferir seus sentimentos, mentiu dizendo:

"Desculpe-me, Amira, fiquei surpreso, eu realmente estou estupefato, e você é árabe... não sei o que..."

"Muito embora tentem me aprisionar, de maneira alguma podem prender o que há em meu corpo. Eu sou um ser humano antes de ser árabe. Você deve ter percebido a atração que tenho por você. E me vi rendida à natureza dela, que é te provocar. Eu sabia que, mesmo que eu me atirasse em cima de você, você não me censuraria, mas me justificaria deste meu ato."

Nicholas ficou de língua atada, sentiu remorso, sabia que não ficaria armado.

"Desculpe-me, é que eu..."

"Eu sei, eu sei que o homem não é como um guarda-chuva automático que apertando o seu botão ele se arma."

$* * * *$

Afora a questão identitária discutida nesse excerto, no excerto acima, deparamonos com uma passagem em que, para além das questões identitárias suscitadas entre a personagem árabe e seu interlocutor britânico, temos a expressão árabe “ينعقد لسانه", que 
significa "estar de língua atada, ou amarrada", o que seria equivalente à expressão, no português, "ficar sem palavras".

Apesar de essa expressão ser bastante comum em língua portuguesa e, de certo modo, veicular o sentido apresentado no texto de partida, fizemos a opção de introduzir a expressão "ficar de língua atada", haja vista que, pelo contexto, o leitor não teria problemas na compreensão do sentido. Para endossar nossa ideia, entendemos que a existência da expressão "ficar de mãos atadas", cujo significado é "a impossibilidade de se fazer alguma coisa", diminuiria todo o estranhamento causado pela presença dessa fraseologia incomum no português brasileiro.

O segundo ponto a ser analisado nesse trecho é o paralelismo estabelecido entre "sabia que não ficaria armado" e "o homem não é como um guarda-chuva automático que apertando o seu botão ele se arma". Ambas as sentenças são construídas no árabe com o mesmo verbo “"انتصب", cujo significado é "se erigir, se erguer, se levantar”. Dado isso, buscamos solucionar essa passagem encontrando um verbo em português que pudesse também ser usado nas duas sentenças, de modo que o paralelismo fosse reproduzido.

Sendo assim, recorremos ao verbo "armar" que, na língua vernácula brasileira,apresenta o mesmo sentido sexual da primeira sentença, quando associado à "barraca", através da fraseologia "ficar de barraca armada", que, na outra sentença, seria recuperada na imagem do "guarda-chuva", que também se "arma".

No diálogo discutido, vimos serem colocadas em pauta questões identitárias e de estereótipos consolidados na comunidade britânica. A personagem árabe, ao seduzir o inglês, se depara com o confronto de sua identidade árabe enunciada pelo interlocutor e precisa lembrar-lhe de que, antes de ser árabe, ela é um ser humano e que não está limitada às imposições e à dominação de seu corpo, sejam elas de cunho religioso ou social. Diante da alteridade, ela é obrigada a se impor enquanto um sujeito que, sim, tem direito e poder sobre o próprio corpo.

Não obstante a importância desse episódio para o escopo da obra, a versão inglesa manipulou de modo significativo o trecho, reduzindo a fala da personagem ao que se segue:

However hard they try, they can't imprison my body. I can be myself with you. I knew that even if I threw myself at you you wouldn't judge me too harshly (p. 51). 
É interessante observar que a atitude tradutória exemplificada através da passagem supracitada reforça a ideia de que, embora a tradução seja convocada a atuar como o espaço da diferença, onde se é possível mobilizar resistência e quebra de estereótipos, ela pode também domesticar o Outro, calando sua voz, de modo a tornar o texto mais palatável para o público leitor na comunidade de chegada. Como citado anteriormente, o teórico aponta que essas estratégias tradutológicas são bastante recorrentes na tradição anglo-americana (VENUTI, 2013).

Essa postura observada no trecho supracitado repete-se de diversas formas em outros momentos da narrativa. Em alguns casos, ao invés de omitir a fala de um determinado personagem, como ocorreu no exemplo anterior, a tradutora da versão inglesa introduz falas que não constam no texto em árabe. O excerto que se segue exemplifica claramente esse fenômeno.

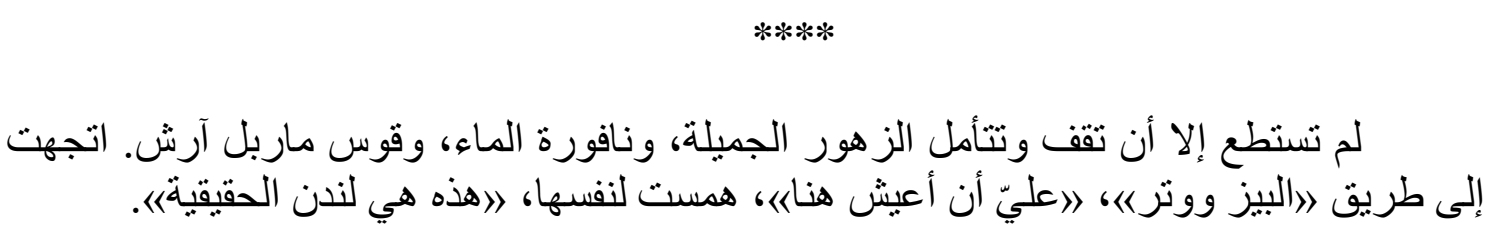

Não se conteve e parou a contemplar as belas flores, a fonte de água, e o arqueado do Marble Arch. Seguiu o caminho em direção a Bayswater. "Eu tenho que morar aqui", murmurou para si mesma "esta é a Londres verdadeira".

$* * * *$

Neste trecho, Amira, que caminha nas redondezas de uma das regiões mais caras e mais conhecidas da cidade de Londres, é seduzida pela ostentação local. No entanto, nessa fala, a personagem, em momento algum, faz referência ao lugar onde mora, como sugerido pela tradução inglesa:

Before she turned towards Bayswater road, she couldn't help but stop to admire the flowers and fountains and the curve of Marble Arch. I ought to live here, she thought. This is the real London. Not 'little Arabia' as the English call Edgware Road these days (p.34).

Ao que nos parece, a tradutora, aqui, foi além da fala de Amira, ao incorporar ao enunciado da personagem uma impressão que a prostituta marroquina julga terem os ingleses a respeito da famosa Edgware Road, 'little Arabia': a pequena Arábia. Todavia, a respeito dessa avenida que, de fato, é marcada pela forte presença árabe, seja nos cafés e restaurantes, no comércio local ou ainda nos passantes - que nos permitem ouvir o árabe 
em seus variados dialetos -, é por meio de Nicolas, o personagem britânico, que Hanan Al-Shaykh opina a respeito do status desse lugar.

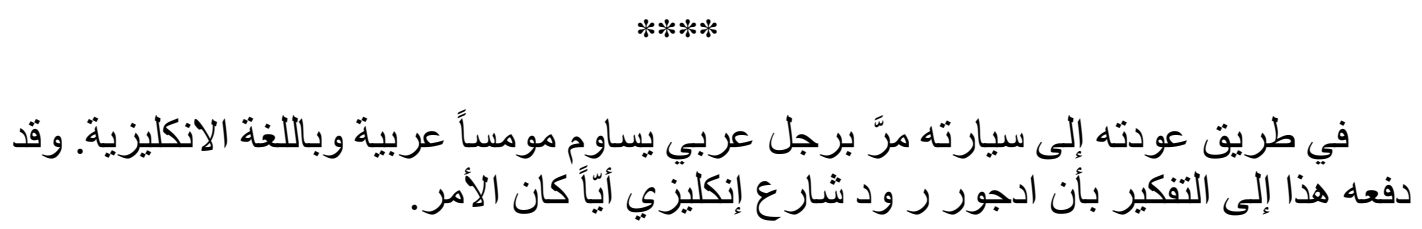

No caminho de volta ao carro passou por um homem árabe que barganhava com uma prostituta árabe, mas em língua inglesa. E levou Nicholas a pensar que, no final das contas, Edgward Road era uma rua inglesa.

$* * * *$

O último exemplo que apresentaremos nessa seção diz respeito precisamente à tradução do árabe para o inglês, na perspectiva de Al-Shaykh, reiterando o que propomos no item 2 deste capítulo, que trata dos Anglicismos, e corroborando nossa proposta de que a autora se mostra totalmente consciente das alterações que as obras árabes sofrem em tradução.

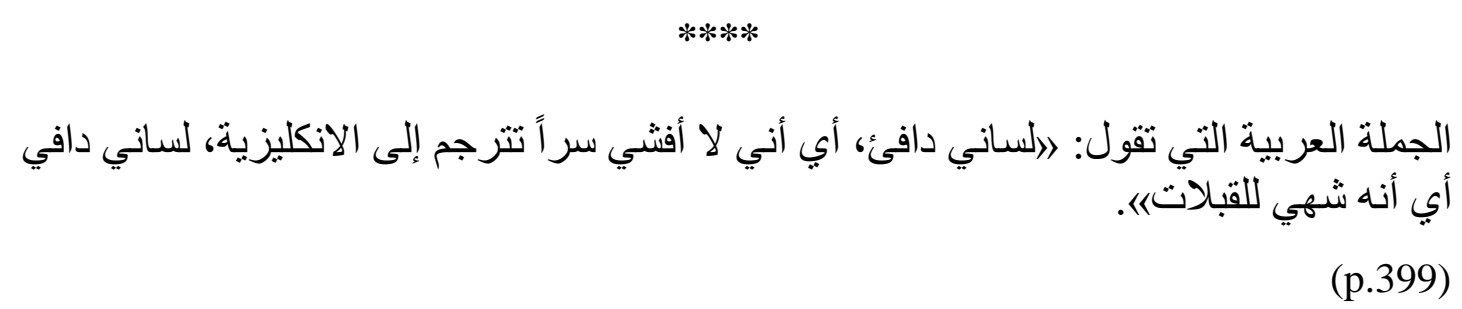

A sentença árabe que diz: "minha língua está quente”, que quer dizer que eu não espalharei teu segredo, é traduzida ao inglês: "lisani dafi" quer dizer por exemplo que minha língua deseja beijos. 


\section{CONSIDERAÇÕES FINAIS}

Tendo em conta que traduções não são meramente apontadas em termos de apropriação cultural, mas são mais prováveis pontos de referência num contexto mais amplo de relações, e um recurso para pensar e revisar práticas e ideologias já existentes, compreendemos que os textos nunca serão assimilados e interpretados exatamente como na sociedade que o produziu, mas sempre será posto na sociedade de recepção e utilizado de acordo com suas necessidades específicas. Além disso, entendemos que a tradução não tem a função de transmitir uma visão geral de outra cultura, mas, pelo contrário, de prover elementos que, de certa forma, acrescentam-se às imagens que representam uma cultura, de modo a construir identidades culturais na comunidade receptiva.

Haja vista o panorama de tradução da literatura árabe no Brasil, e o exíguo conjunto de obras traduzidas que represente elementos da cultura árabe que contribuam para a formação da identidade cultural dos povos árabes, Innahā London ya 'azizzī apresenta-se não só como veículo de ilustração da multiculturalidade que envolve o 'ser árabe', mas também da relação que esses indivíduos têm na diáspora, bem como de suas próprias impressões sobre si mesmos e sua contraparte europeia.

Al-Shaykh, nesse texto, tentou abarcar as diversas facetas que compreendem a vida do imigrante árabe na cidade de Londres, incumbindo-se da tarefa de trazer à tona até mesmo os detalhes do cotidiano, os quais podem passar despercebidos pelo próprio imigrante que, no processo de imersão no novo espaço, deixa escapar assunções sobre a alteridade que se dão em conversas comezinhas, impressões sobre lugares e pessoas, baseadas na vivência com o estrangeiro.

No processo de criação desse caleidoscópio cultural, Al-Shaykh, talvez conscientemente, abra mão de uma estrutura narrativa que se fundamente numa estética mais tradicional, visto que sua intenção principal nesse texto seria reproduzir o máximo de facetas possíveis da experiência migratória, a fim de representar, ainda que em parte, realidades particulares de sujeitos distintos de origens diversas, que são decalcados pelo conceito ocidental do 'ser árabe'.

Talvez o romance deva algo em termos estéticos e estruturais, no que diz respeito aos modelos estabelecidos pela crítica, como apontou El-Youssef em sua análise. No entanto, percebemos que a escritora, ousadamente, fez a dura escolha de decidir não produzir um texto que apresentasse uma estética adequada a padrões determinados. 
Arriscando-se conscientemente ao desprestígio da crítica, optou por transformar sua narrativa num espaço de provocação, criando, assim, uma nova estética. E isto nos parece nítido quando Al-Shaykh, através da linguagem e de elementos culturais, cria um caleidoscópio dentro dos limites do romance. No espaço do discurso, ela consegue tocar em questões bastante delicadas, que envolvem diversos aspectos do sujeito imigrante, sua relação com a alteridade e seus espaços. Se nos achegamos ao texto com essa perspectiva, conseguimos atribuir um propósito à obra, que não fica restrita à arte pela arte.

Ao inserir referências a documentos, como os da British Library, manuscritos da Biblioteca de Damasco, a poesia de Adonis, assim como a retomada de todo o pensamento de Edward Said expressos nas obras Orientalismo, o Oriente como invenção do Ocidente (2006) e Cultura e Imperalismo (2009), a escritora parece não só querer dar um ar documental, mas revelar uma maturidade intelectual e discursiva que caracteriza o trabalho das romancistas árabes desde sua emergência.

Retomando debates importantes da história e política dos países árabes, bem como das relações Inglaterra-Oriente Médio, a obra se constrói por meio de críticas sutis e desveladas, impondo-se como espaço de provocação e desconforto, tanto para os árabes como para os ingleses. Ao expor o envolvimento dos conservadores de dishdashas brancas - o homem do Golfo - com prostitutas árabes na Europa, Al-Shaykh toca numa questão sensitiva também entre as comunidades muçulmanas de toda uma região que pode ser indicada por essa generalização. A autora ainda traz à tona as diversas confusões que os britânicos fazem com as identidades orientais, por meio de generalizações e homogeneizações, e a expressão desse suposto conhecimento de sua contraparte árabe, através de menções de orientalistas reiteradamente criticados por Said (2006; 2009). AlShaykh não poupa nenhum dos lados.

Ao representar diferentes nacionalidades árabes em sua obra, a escritora busca corrigir a errônea ideia cunhada no imaginário ocidental de uma identidade árabe homogeneizada e genérica. Ao dar voz aos silenciados no processo de imigração, revelanos a luta interna de sujeitos que buscam o autoconhecimento no espaço da diferença, e como o fato de serem estrangeiros torna a vida de cada um deles um desafio diário.

Pensando no romance enquanto espaço de provocação, Al-Shaykh, ao intitular sua obra 'É Londres, meu caro' e atribuir à fala de uma de suas personagens que 'os lugares são pessoas' (p. 24), faz do seu romance não só um espelho da cidade, mas da sua 
população, e ela reitera isso, quando usa a voz de seu único personagem inglês para dizer 'nós, os ingleses, somos estranhos, somos tímidos' (p. 237). Valendo-se da mesma artimanha desenvolvida por séculos em traduções e textos europeus, ela afirma a identidade árabe e define a alteridade segundo sua perspectiva.

A originalidade de sua obra não reside no seu enredo, tampouco na temática abordada, mas sim na forma. A estética que Hanan Al-Shaykh cria nesse texto o distingue de seus pares, não porque trata de assuntos que foram discutidos na literatura há décadas, mas sua novidade está na expressão singular da multiculturalidade, do multilinguismo e das questões identitárias que emergem da experiência da imigração. Por dispor de tantas variedades dialetais do árabe, assim como representar a língua inglesa e sua variedade londrina, seu texto constitui-se um repositório linguístico, manifestando a experiência linguística do imigrante.

Compreendendo que a natureza e função da obra direciona as decisões tomadas ao longo do processo criativo que nos leva ao texto final, o papel do tradutor enquanto mediador intercultural torna-se fundamental diante de um texto que trata de questões tão sensíveis ao imigrante e sua dura tentativa de se estabelecer no país estrangeiro, sob sua cultura, língua, políticas, preconceitos e estereótipos. Disso emerge a necessidade do tradutor ser fiel a esse texto e manter-se ético no seu fazer tradutório, para que essa literatura cumpra sua função no processo dialógico que se dá no sistema literário de recepção.

Considerando as traduções do romance por nós visitadas, fica o questionamento se a manipulação textual, através dos processos de apagamento, explicações, adições e supressões textuais, verificadas principalmente na tradução inglesa, foram realizadas intencionalmente, apenas com vistas a tornar o texto mais palatável para o público-alvo, que já está habituado a determinado estilo literário e não se interessa por qualquer coisa que fuja a esse padrão, pois leva-o ao lugar de desconforto, isto é, ao espaço de confrontamento com a alteridade e questões com as quais não se tem a intenção de lidar. Ou seria essa prática de manipulação um sintoma daquilo que denominamos, neste trabalho, gênero orientalista, estabelecendo-se como uma tradição de tradução que tem em vista uma agenda que anula quase que completamente a função desse discurso no processo de diálogo entre culturas, corroborando a ideia de que forças ideológicas organizam ainda sistemas literários na estratificação geopolítica que classificam as nações e suas culturas como Povos do Norte e Povos do Sul. 


\section{REFERÊNCIAS BIBLIOGRÁFICAS}

\section{Texto do Corpus:}

AL-SHAYKH, H. Innaha London ya cazizi. Beirut: Dar-Al-Adab, 2001.

\section{Obras da base teórica e metodológica}

ADONIS. An introduction to Arab Poetics. British Library, 2003.

AL-'IDA, Y. Lebanon. Arab Women Writers. A Critical Reference Guide 1873-1999.

Edited by: Radwa Ashour, Ferial J. Ghazoul and Hasna Reda-Mekdashi. Translated by: Mandy McClure.

ALLEN, R. The Beginnings of the Arabic Novel. Chapter 5 In: Modern Arabic Literature. 1992

Pioneer Translator Roger Allen on a Text He's Been Working with for the

Last 50 Years. Em entrevista para ArabLite - Arabic Literature and Translation. 14 de Setembro de 2015.

Disponível em: <https://arablit.org/2015/09/14/pioneer-translator-roger-allen-on-a-texthes-been-working-with-for-the-last-50-years/> Último acesso: 04/06/2018.

AL-MAHROOQI, R.; DENMAN, C. Arab identity and literature in translation: The politics of selection and representation. Arab World English Journal (AWEJ), Special Issue on Translation, n. 5, p. 5-20, May 2016.

AL-SAMMAN, H. Border Crossings: Cultural Collisions and Reconciliation in Hanan Al-Shaykh's Only in London. In: MENON, N. and PREZIUSO, M. (Ed.) Migrant identities of Creole cosmopolitans: transcultural narratives of contemporary postcoloniality. New York: Peter Lang, 2014.

AL-SHAYKH, H. Eso es London. Barcelona: Ediciones del Bronce, 2002.

Only in London. London: Anchor Books, 2002.

Em entrevista para: Raba'i Al-Madhoun. The Arabic Novel in the West.

July 19, 2013a. <<https://allsanaa.wordpress.com/2013/07/23/the-arabic-novel-in-thewest-part/ >> (último acesso 05/07/2017, 15:28)

Em entrevista: Scheherazade: From Storytelling 'Slave' To 'First

Feminist'. June 9, 2013b. Heard on Weekend Edition Sunday. Disponível em: <<https://www.npr.org/2013/06/09/189539866/scheherazade-from-storytelling-slave-to-firstfeminist $>$ (Último acesso em 28/03/2018).

Em entrevista: em entrevista ao Jornal Al-Akhbar 22/04/2016 Coluna

Kalimāt: kitāby al-‘Awal. Disponível em: <<https://www.al- 
akhbar.com/Kalimat/120738/\%D8\%AD\%D9\%86\%D8\%A7\%D9\%86\%D8\%A7\%D9\% 84\%D8\%B4\%D9\%8A\%D8\%AE\%D8\%A7\%D9\%86\%D8\%AA\%D8\%AD\%D8\%A7\% D8\%B1-\%D8\%B1\%D8\%AC\%D9\%84-\%D9\%85\%D9\%8A > (Último acesso: $13 / 06 / 19)$.

The New Shahrazad. Sweet Briar College World Writers Series - March 15, 2000. Texto fornecido pelo autor para Gifts Speech $-<<$ http://gos.sbc.edu/a/AlShaykh.html >> (Último acesso: 28/03/2018).

Em entrevista: Conversation: Salman Rushid \& Hanan Al-Shaykh. PEN

World Voices $2005 . \quad$ Festival, em: <<https://www.youtube.com/watch?v=fOXhzlN3jxQ>>. (Último acesso: 01/10/2019)

ALVES, J. O contexto de tradução de literatura árabe contemporânea e o papel do tradutor enquanto mediador intercultural. Revista Malala, v. 7, n. 10, 2019. No prelo.

ALVES \& JUBRAN. No tempo de migrar. Revista Criação \& Crítica, n. 24, 2019. No prelo.

BAKHTIN, M. Os gêneros do discurso. In: Estética da criação verbal. São Paulo: Martins Fontes, 1997.

BERMAN, A. A tradução e a Letra ou o Albergue do Longínquo. Rio de Janeiro: 7Letras/PGET, 2007.

CAMPOS, H. Da tradução como criação e crítica. Metalinguagem \& outras metas: ensaios de teoria e crítica literária. São Paulo: Perspectiva, 2004.

COOKE, M. Arab women writers. In: BADAWI, M. M. (Ed.). Modern Arab literature. Cambridge: Cambridge University Press, 2005.

EL-ENANY, R. Arab representation of the Occident. East-West Encounters in Arabic Fiction. London; New York: Routledge, 2006.

EL-YOUSSEF, S. سمير اليوسف "انها لندن يا عزيزي" رو اية حنان الثيخ الجديدة انعدام رؤية يُنتج بناءً مفككاً . Innahā London ya 'azīz̄ì , romance de Hanan Al-Shaykh resulta em estrutura frágil e narrativa defectiva. Disponível em: <<https://elaph.com/Web/Archive/983123916551400300.html〉> (último acesso: 01/04/2019).

FRANCISCO, F. B. Pode entrar Meryl Streep! A ética da tradução em um romance de Rashid Daif. São Paulo, 2014.

HATIM, Basil; MASON, Ian. "Context in Translating: Register Analysis". In: Discourse and the Translator. London/New York: Longman, 1990, pp. 36-54. 
JUBRAN, S. A. A-C. Para uma romanização padronizada de termos árabes em textos de língua portuguesa. Revista Tiraz, v. 1, n. 1, 2004.

LARSON, Charles R. The Fiction of Hanan Al-Shaykh, Reluctant Feminist. World Literature Today. Vol. 65, No. 1 (Winter, 1991), pp. 14-17. Published by: Board of Regents of the University of Oklahoma. Disponível em: <http://www.jstor.org/stable/40146112>. (Último acesso em: 16/06/2018)

NORD, C. Translating as a purposeful activity. Functionalist approaches explained. Manchester: St. Jerome Publishing, 2007.

SAID, E. Orientalismo: o Oriente como invenção do Ocidente. São Paulo: Cia. das Letras, 2006.

Cultura e Imperialismo. São Paulo: Companhia de Bolso, 2009.

SCHLOTE, C. An interview with Hanan al-Shaykh. Literary London: Interdisciplinary Studies in the Representation of London, v. 1, n. 2, Sept. 2003. Disponível em: <http://www.literarylondon.org/london-journal/september2003/schlote.html>. Accesso em: 24 maio 2017.

SIRHAN, R. Al-taqnyyāt al-sardyya ${ }^{\mathrm{t}}$ wa 'alāqatihā bi-ḍamūn al-hițāb al-'adabiy 'and Hanān Al-Šayh. In: Al-Maajalla. Journal of the Arabic Language Academy. Nazareth, Vol. 7, 2016.

SHAABAN, Bouthania.Voices revealed. Arab Women Novelists, 1898-2000. Colorado: Lynne Rienner Publishers, 2009.

STARKEY, P. The sixties generation and beyond. In: Modern Arabic Literature. Edinburgh: Edinburg University Press, 2006.

VAN LEEUWEN, R. The cultural Context of Translating Arabic Literature. In: FAIQ, S.

(Ed.) Cultural Encounters in Translation from Arabic. Clevedon: Multilingual Matters LTD, 2004.

VENUTI, L. The scandals of translations. Towards an ethics of difference. London; New York: Routledge, 1998.

VENUTI, L. The translator's invisibility. A history of translation. London; New York: Routledge, 1995.

VENUTI, L. Translation changes everything. Theory and Practice. London; New York: Routledge, 2013.

\section{Outras obras de referência}

CORRIENTE, Federico \& FERRANDO, Ignacio. Diccionario Avanzado Árabe. Spain: Herder, 2005. 
WEHR, Hans. A Dictionary of Modern Written Arabic. New York: Spoken Language Services Inc., 1976. 